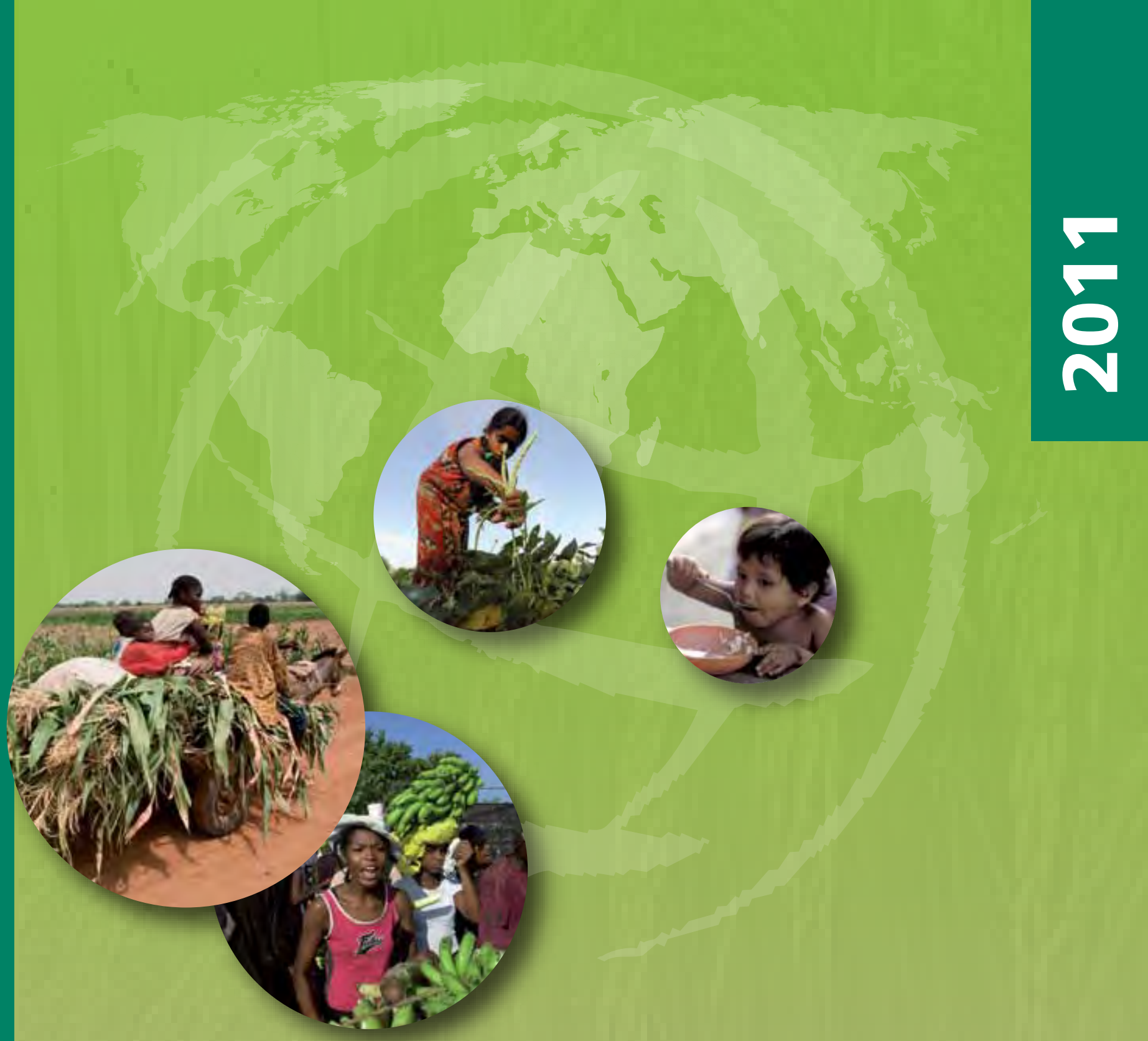

El estado de la inseguridad alimentaria en el mundo

¿Cómo afecta la volatilidad de los precios internacionales a las economías nacionales y la seguridad alimentaria?
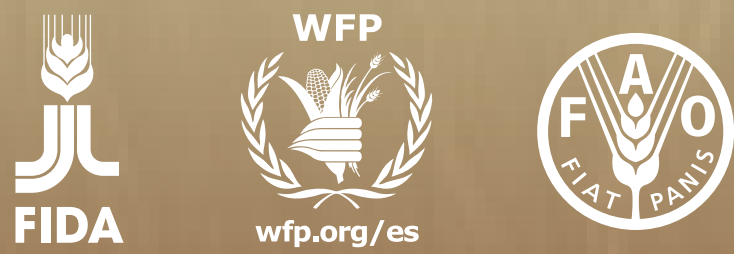
Los países pequeños dependientes de las importaciones, especialmente en África, se vieron profundamente afectados por la crisis de los alimentos y la crisis económica. Algunos países grandes lograron aislarse de la crisis mediante políticas comerciales restrictivas y redes de seguridad efectivas. Sin embargo, el aislamiento comercial aumentó el nivel de los precios y su volatilidad en los mercados internacionales.

Es probable que los precios de los alimentos sigan siendo elevados y volátiles. La demanda de los consumidores en los países con economía en rápido crecimiento aumentará, la población continúa creciendo, y si prosigue la expansión de los biocombustibles el sistema alimentario se verá sometido a demandas adicionales. En el lado de la oferta, se plantean desafíos debido a la creciente escasez de los recursos naturales en algunas regiones y a la disminución de las tasas de crecimiento de los rendimientos de algunos productos básicos. La volatilidad de los precios de los alimentos podría incrementarse debido a los vínculos más estrechos entre los mercados agrícolas y energéticos, así como a la mayor frecuencia de las perturbaciones causadas por fenómenos meteorológicos.

La volatilidad de los precios hace que los pequeños agricultores y los consumidores pobres sean cada vez más vulnerables a la pobreza. Dado que los alimentos constituyen una gran proporción de los ingresos de los agricultores y del presupuesto de los consumidores pobres, los aumentos significativos de los precios tienen efectos considerables en los ingresos reales. Por ello, incluso episodios breves de alza de los precios a los consumidores o descenso de los precios a los agricultores pueden provocar la venta a bajo precio de activos productivos, como tierra y ganado, por ejemplo, lo cual puede dar lugar a la trampa de la pobreza. Además, cuando las variaciones de los precios son imprevisibles, la probabilidad de que los pequeños agricultores inviertan en medidas encaminadas a aumentar la productividad es menor.

Unos cambios significativos de los precios a corto plazo pueden tener repercusiones a largo plazo en el desarrollo. Los cambios en los ingresos debido a las fluctuaciones de los precios pueden hacer que se reduzca el consumo por los niños de nutrientes esenciales durante los primeros 1000 días de vida desde el momento de la concepción, lo que a su vez causa una reducción permanente de su capacidad de obtener ingresos en el futuro, aumenta la probabilidad de que resulten afectados por la pobreza en el futuro y, en consecuencia, provoca una ralentización del proceso de desarrollo económico.

Unos precios altos de los alimentos intensifican la inseguridad alimentaria a corto plazo. Los beneficios recaen principalmente en los agricultores que disponen de acceso adecuado a la tierra y otros recursos, mientras que los más pobres de entre los pobres compran más alimentos de los que producen. Además de perjudicar a los pobres de las zonas urbanas, los precios elevados de los alimentos perjudican también a gran parte de los pobres de las zonas rurales, que normalmente son compradores netos de alimentos.
La diversidad de las repercusiones dentro de cada país apunta también a la necesidad de mejorar el análisis de los datos y las políticas.

Unos precios altos de los alimentos presentan incentivos para incrementar la inversión a largo plazo en el sector agrícola, lo que puede contribuir a mejorar la seguridad alimentaria a más largo plazo. Los precios nacionales de los alimentos, tanto al por menor como a la salida de la explotación agrícola, se incrementaron considerablemente en la mayoría de los países durante la crisis alimentaria mundial de 2006-08. Pese a los altos precios de los fertilizantes, esto condujo a una robusta respuesta de la oferta en muchos países. Es esencial aprovechar esta respuesta de la oferta a corto plazo incrementando la inversión en la agricultura, incluso mediante iniciativas dirigidas a los pequeños agricultores y que les ayudan a lograr acceso a los mercados, como la iniciativa Compras en aras del progreso.

Las redes de seguridad son cruciales para mitigar la inseguridad alimentaria a corto plazo, así como para proporcionar una base para el desarrollo a largo plazo. Para lograr la reducción efectiva de las consecuencias adversas de la volatilidad de los precios, es preciso elaborar por anticipado mecanismos de redes de seguridad selectivas en consulta con los grupos de población más vulnerables.

Una estrategia de seguridad alimentaria basada en una combinación de mayor productividad de la agricultura, mayor previsibilidad de las políticas y apertura general al comercio será más eficaz que otras estrategias. Las políticas comerciales restrictivas pueden proteger los precios internos de la volatilidad del mercado mundial, pero estas políticas pueden redundar asimismo en un aumento de la volatilidad de los precios internos como resultado de las crisis del suministro interno, especialmente si las políticas públicas son imprevisibles y erráticas. Unas políticas gubernamentales más previsibles y que promuevan la participación del sector privado en el comercio disminuirán, en general, la volatilidad de los precios.

La inversión en la agricultura sigue siendo fundamental para lograr una seguridad alimentaria sostenible a largo plazo. Esa inversión mejorará la competitividad de la producción interna, incrementará las ganancias de los agricultores y hará que los alimentos sean más asequibles para los pobres. Por ejemplo, unos sistemas de riego eficaces con respecto a los costos y prácticas y semillas mejoradas gracias a la investigación agrícola pueden reducir los riesgos de producción a los que se enfrentan los agricultores, especialmente los pequeños agricultores, y reducir la volatilidad de los precios. Aunque la mayor parte de la inversión necesaria corresponderá al sector privado, la inversión pública debe cumplir una función catalizadora al proporcionar bienes públicos que el sector privado no suministraría. Estas inversiones deberían tener en cuenta los derechos de los actuales usuarios de la tierra y los recursos naturales conexos, beneficiar a las comunidades locales y promover la seguridad alimentaria, y no deberían causar daños indebidos al medio ambiente. 
El estado de la

\section{inseguridad alimentaria en el mundo}

¿Cómo afecta la volatilidad de los precios internacionales a las economías nacionales y la seguridad alimentaria? 
Las denominaciones empleadas en este producto informativo y la forma en que aparecen presentados los datos que contiene no implican, por parte de la Organización de las Naciones Unidas para la Alimentación y la Agricultura (FAO), del Programa Mundial de Alimentos (PMA) o del Fondo Internacional de Desarrollo Agrícola (FIDA), juicio alguno sobre la condición jurídica o nivel de desarrollo de países, territorios, ciudades o zonas, o de sus autoridades, ni respecto de la delimitación de sus fronteras o límites. La mención de empresas o productos de fabricantes en particular, estén o no patentados, no implica que la FAO, el PMA o el FIDA los aprueben o recomienden de preferencia a otros de naturaleza similar que no se mencionan.

Las denominaciones empleadas en los mapas y la forma en que aparecen presentados los datos no implican, por parte de la FAO, el PMA o el FIDA, juicio alguno sobre la condición jurídica de países, territorios o zonas marítimas, ni respecto de la delimitación de sus fronteras.

\section{ISBN 978-92-5-306927-9}

Todos los derechos reservados. La FAO fomenta la reproducción y difusión del material contenido en este producto informativo. Su uso para fines no comerciales se autorizará de forma gratuita previa solicitud. La reproducción para la reventa u otros fines comerciales, incluidos fines educativos, podría estar sujeta a pago de tarifas. Las solicitudes de autorización para reproducir o difundir material de cuyos derechos de autor sea titular la FAO y toda consulta relativa a derechos y licencias deberán dirigirse por correo electrónico a: copyright@fao.org, o por escrito al

Jefe de la Subdivisión de Políticas y Apoyo en materia de Publicaciones Oficina de Intercambio de Conocimientos, Investigación y Extensión

FAO

Viale delle Terme di Caracalla

00153 Roma (Italia) 
8 La subnutrición en el mundo: repercusión de la crisis de los precios de 2006-08

8 La crisis afectó a las poblaciones pobres y vulnerables

10 Revisión de la metodología de la FAO para la medición del hambre

11 Tendencias recientes en los precios mundiales de los productos alimenticios básicos: costos y beneficios

11 Tendencias pasadas y futuras de los precios mundiales de los alimentos

14 Costos y beneficios de los precios altos y bajos de los alimentos

20 Costos y beneficios de los precios volátiles e imprevisibles

23 Enseñanzas de la crisis alimentaria mundial de 2006-08

35 Opciones en materia de políticas para hacer frente a la volatilidad y los altos precios

37 Prevenir la volatilidad de los precios internos a corto plazo: políticas comerciales y reservas de estabilización

41 Cómo hacer frente a la probable volatilidad futura de los precios: la gestión de riesgos para los pequeños agricultores y los gobiernos

44 Cómo hacer frente a la volatilidad de los precios cuando ya existe: redes de seguridad selectivas y reservas alimentarias de emergencia

47 Cómo prevenir la volatilidad de los precios a largo plazo: incremento de la productividad, la sostenibilidad y la capacidad de resistencia de la agricultura

\section{Anexo técnico}

50 Cuadro anexo

Prevalencia de la subnutrición y progreso hacia la consecución del objetivo de la Cumbre Mundial sobre la Alimentación (CMA) y la meta del primer Objetivo de Desarrollo del Milenio (ODM) en los países en desarrollo

$54 \quad$ Notas 
os países pequeños dependientes de las importaciones, especialmente en África, se vieron gravemente afectados por la crisis de los alimentos y la crisis económica. De hecho,

muchos países en diferentes partes del mundo, en particular en el Cuerno de África,

siguen sufriendo la crisis. Estas crisis están dificultando nuestros esfuerzos con miras a alcanzar el Objetivo de Desarrollo del Milenio (ODM) de reducir a la mitad la proporción de personas que sufren hambre para mediados de 2015. Por más que este ODM llegara a alcanzarse en 2015, en los países en desarrollo seguiría habiendo unos 600 millones de personas subnutridas. El hecho de que haya 600 millones de seres humanos que padecen hambre todos los días no puede jamás ser aceptable. Toda la comunidad internacional debe actuar ya, y hacerlo enérgica y

responsablemente, a fin de desterrar del planeta la inseguridad alimentaria.

La presente edición de El estado de la inseguridad alimentaria en el mundo está dedicada a la volatilidad de los precios de los alimentos. Nuestras organizaciones continúan vigilando los precios de los alimentos y han alertado al mundo mediante diversos informes analíticos sobre las tendencias y la volatilidad constante de los precios alimentarios en los últimos años, ya que estos siguen suscitando la preocupación de los gobiernos y las personas en todo el mundo. De hecho, en general se prevé que los precios de los alimentos seguirán siendo altos y volátiles en el futuro. Por esa razón, nos complace que en 2011 los ministros de Finanzas y los gobernadores de los bancos centrales del Grupo de los Veinte (G-20) hayan tratado activamente de hallar opciones en materia de políticas para reducir la volatilidad de los precios de los alimentos.

Mediante el uso de fuentes de datos y estudios que no estaban disponibles anteriormente, este informe excava bajo los análisis de escala mundial para averiguar qué sucedió en los mercados nacionales y extraer enseñanzas de la crisis alimentaria mundial de 2006-08. En particular, el informe hace hincapié en que las variaciones de los precios mundiales repercuten en la seguridad alimentaria y la nutrición de los hogares de manera sumamente específica en función del contexto. Las repercusiones dependen del producto básico concreto, de las políticas nacionales que afectan a la repercusión de los precios de los mercados mundiales en los mercados internos, de las características demográficas y productivas de los distintos hogares y de una variedad de otros factores. Esta diversidad de las repercusiones, tanto entre los diferentes países como dentro de cada uno de ellos, apunta a la necesidad de mejorar los datos y el análisis de modo que los gobiernos puedan aplicar mejores políticas. Unas políticas mejores y más previsibles pueden permitir no solo reducir los efectos secundarios no deseados en otros países, sino también reducir simultáneamente la inseguridad alimentaria y la volatilidad interna de los precios en el propio país. En este informe se hace asimismo una distinción clara entre el nivel de los precios de los alimentos y las fluctuaciones de dichos precios (la volatilidad de los precios) ya que los costos y beneficios de los altos precios de los alimentos son muy distintos de los costos de la volatilidad de los precios, especialmente cuando sus fluctuaciones no son previsibles.

Seguimos igualmente destacando la importancia de un enfoque de doble componente - mejorar el acceso a corto plazo a los alimentos y acrecentar la producción alimentaria a medio plazo- a fin de lograr mejoras duraderas de la seguridad alimentaria.

A corto plazo, es esencial diseñar redes de seguridad eficaces con respecto a los costos, que proporcionen la asistencia selectiva adecuada a las personas adecuadas en el momento adecuado. Estas intervenciones a corto plazo son importantes para las familias pobres porque interrupciones incluso temporales de la ingesta de energía, proteínas, vitaminas y minerales durante los primeros 1000 días de vida de un niño pueden determinar reducciones permanentes de sus capacidades cognitivas y, por consiguiente, de su potencial para obtener ingresos. Se tratará, en ciertos casos, de los consumidores cuyos ingresos disponibles se ven gravemente afectados por el incremento de los precios de los productos alimenticios. En otros, los necesitados serán los pequeños agricultores pobres, que precisan ayuda para hacer frente a los precios elevados de los insumos que, en ausencia de mercados de crédito que funcionen adecuadamente, pueden impedir que estos agricultores incrementen su producción y proporcionen los suministros que tanto se necesitan a los mercados nacionales y mundiales, además de acrecentar sus ingresos.

A largo plazo, la inversión en agricultura y la mejora de la capacidad de resistencia de los agricultores siguen siendo la clave para proporcionar acceso sostenido a los alimentos a todas las personas y para reducir la vulnerabilidad a la volatilidad de los precios y las catástrofes naturales como la sequía. Es preciso que tanto el sector privado como el público proporcionen a los 
agricultores, especialmente en pequeña escala, semillas mejoradas y técnicas de gestión agrícola, así como riego y fertilizantes, que aumenten en forma sostenible su productividad y reduzcan su riesgo productivo. Los gobiernos deben asegurarse de que se cuente con un entorno normativo transparente y previsible que promueva la inversión privada y favorezca el aumento de la productividad agrícola.

Debemos reducir el desperdicio de alimentos en los países desarrollados por medio de la educación y de políticas adecuadas y reducir las pérdidas de alimentos en los países en desarrollo mediante un incremento de la inversión en toda la cadena de valor, especialmente en la elaboración poscosecha. Una gestión más sostenible de nuestros recursos naturales, forestales y pesqueros es fundamental para la seguridad alimentaria de muchos de los miembros más pobres de la sociedad.

Confiamos en que se logrará la seguridad alimentaria mundial. Hemos logrado avances en el pasado y lograremos avanzar más en el futuro, pero solo lo conseguiremos si nos comprometemos a proporcionar políticas favorables, información sobre los mercados transparente, análisis sólidos, adecuados conocimientos científicos y una financiación suficiente para las intervenciones apropiadas. Toda la comunidad internacional deberá comprometerse para resaltar mejor el papel del sistema agroalimentario no solamente durante unos pocos años sino hasta que todas las personas, en todo momento, puedan disponer de acceso físico, social y económico a alimentos suficientes, seguros y nutritivos, acordes a sus necesidades dietéticas y sus preferencias alimentarias, para poder llevar una vida activa y sana. E incluso entonces, la agricultura y la seguridad alimentaria deberán seguir siendo una prioridad tanto para los gobiernos nacionales como para la comunidad mundial a fin de velar por la sostenibilidad de los logros. El aumento de la inversión en la agricultura, redes de seguridad dirigidas a las personas más vulnerables y medidas encaminadas a reducir la volatilidad de los precios de los alimentos deben ser parte integral de este compromiso.

La presente es la tercera edición de este informe, producido en colaboración entre la FAO y el Programa Mundial de Alimentos (PMA) en lo que ha demostrado ser un fructífero esfuerzo conjunto. Este año, por primera vez, también el Fondo Internacional de Desarrollo Agrícola (FIDA) se ha unido a esta colaboración. Con el trabajo conjunto de nuestras tres organizaciones, esperamos que el informe siga creciendo en lo que atañe a la pertinencia de sus análisis y la solidez de sus resultados. Deseamos también agradecer al Departamento de Agricultura de los Estados Unidos de América su constante voluntad de compartir sus conocimientos especializados y aportar contribuciones a este informe.

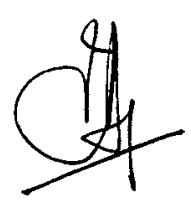

Jacques Diouf

Director General de la FAO

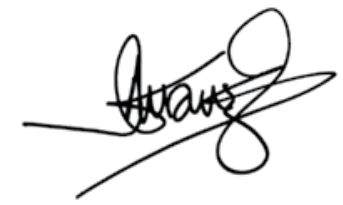

Kanayo F. Nwanze

Presidente del FIDA

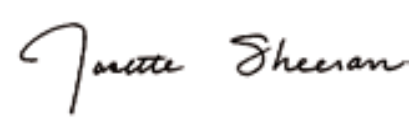

Josette Sheeran

Directora Ejecutiva del PMA 
El estado de la inseguridad alimentaria en el mundo 2011 se preparó bajo la dirección general de Hafez Ghanem, Subdirector General, y con la orientación del equipo directivo del Departamento de Desarrollo Económico y Social. La coordinación técnica de la publicación estuvo a cargo de David Dawe (que también se encargó de la edición técnica del informe), Kostas Stamoulis y Keith Wiebe, de la División de Economía del Desarrollo Agrícola (ESA). Michelle Kendrick se ocupó de la coordinación integral de la redacción, las figuras, la maquetación y los servicios de publicación. Anna Doria Antonazzo prestó un apoyo administrativo excelente durante todo el proceso, y el personal de la División de Estadística (ESS) proporcionó los datos de base sobre la subnutrición.

Esta es la tercera edición de este informe que se ha preparado conjuntamente por la Organización de las Naciones Unidas para la Alimentación y la Agricultura (FAO) y el Programa Mundial de Alimentos (PMA). Además, este año también ha participado el Fondo Internacional de Desarrollo Agrícola (FIDA) como coeditor. Lynn Brown (PMA) y Geoffrey Livingston (FIDA) coordinaron el apoyo prestado por las respectivas instituciones. Kevin Cleaver y Shantanu Mathur, del FIDA, también alentaron la realización conjunta de esta edición.

El capítulo sobre la subnutrición en el mundo fue preparado por la División de Estadística del Departamento de Desarrollo Económico y Social de la FAO con la colaboración técnica esencial de Carlo Cafiero, Pietro Gennari, Josef Schmidhuber y Shahla Shapouri (esta última del Servicio de Investigación Económica del Departamento de Agricultura de los Estados Unidos de América [ERS-USDA]).

Los tres capítulos restantes fueron preparados por el Departamento de Desarrollo Económico y Social con la colaboración técnica de Mulat Demeke (ESA); Adam Prakash y George Rapsomanikis (División de Comercio y Mercados [EST]); Ana Paula de la O Campos y Elisabeth Garner (División de Género, Equidad y Empleo Rural [ESW]). El recuadro sobre los bosques y la seguridad alimentaria fue preparado por Paul Vantomme, del Departamento Forestal. Lynn Brown (PMA) realizó el recuadro sobre la experiencia del PMA durante las crisis alimentarias. George Rapsomanikis (EST) aportó el recuadro sobre los resultados de la Cumbre de Ministros de Agricultura del G-20.

Carlo Cafiero y Cinzia Cerri elaboraron el Anexo técnico bajo la dirección de Pietro Gennari, con el apoyo de Gladys Moreno-García, Seevalingum Ramasawmy, Kari Rummukainen y Nathalie Troubat (ESS).

Fueron de gran utilidad las valiosas observaciones, propuestas y aportaciones externas de Derek Headey (Instituto Internacional de Investigación sobre Políticas Alimentarias [IFPRI]) y Peter Timmer (Universidad de Harvard) sobre el primer borrador de este informe, así como las observaciones formuladas en las diversas etapas por Ann Tutwiler, Directora General Adjunta (Conocimiento) de la FAO; Boubaker BenBelhassen (Oficina del Director General [ODG]); Erdgin Mane (ESA); Carlo Cafiero y Josef Schmidhuber (ESS); Merritt Cluff, David Hallam y Jamie Morrison (EST); Eve Crowley (ESW); Hubert George (Departamento de Gestión de Recursos Naturales y Medio Ambiente, División de Tierras y Agua [NRL]); Astrid Agostini, Sophie Descargues, Guy Evers, Claudio Gregorio, Mohamed Manssouri, Suzanne Raswant, Eugenia Serova, Garry Smith y Benoist Veillerette (División de Inversiones [TCI] del Departamento de Cooperación Técnica [TC]); Louis Bockel, Karel Callens, Arianna Carita, Richard China, Gunther Feiler, Stefano Gavotti y David Phiri (Departamento de Cooperación Técnica, División de Apoyo a la Elaboración de Políticas y Programas [TCS]); y Ganesh Thapa, de la División de Asia (FIDA). Ali Doroudian y Cristian Morales-Opazo prestaron un inestimable apoyo de investigación.

Solomon Asfaw y Romina Cavatassi (ESA); Erika Felix e Irini Maltsoglou (División de Clima, Energía y Tenencia de Tierras [NRC] del Departamento de Gestión de Recursos Naturales y Medio Ambiente [NR]); Mousa Kabore (Director) y Adama Koursangama, Dirección de Planificación, Estadísticas Agrícolas y Alimentarias (DPSA), Dirección General de Promoción de la Economía Rural (DGPER), del Ministerio de Agricultura, Aguas y Recursos Pesqueros de Burkina Faso; y Piedad Moya (Instituto Internacional de Investigación sobre el Arroz [IRRI]) aportaron amablemente diversos datos.

La legibilidad del informe mejoró considerablemente gracias al apoyo editorial en inglés de Paul Neate. Flora di Carlo y Visiontime realizaron los servicios de edición, diseño gráfico y maquetación. El Servicio de Programación y Documentación de Reuniones del Departamento de Servicios Internos, Recursos Humanos y Finanzas se encargó de la traducción e impresión del informe. 



\section{La subnutrición en el mundo: repercusión de la crisis de los precios de 2006-08}

\section{La crisis afectó a las poblaciones pobres y vulnerables}

\section{Mensaje principal}

Los países pequeños dependientes de las importaciones, especialmente en África, se vieron profundamente afectados por la crisis de los alimentos y la crisis económica. Algunos países grandes lograron aislarse de la crisis mediante políticas comerciales restrictivas y redes de seguridad efectivas. Sin embargo, el aislamiento comercial aumentó el nivel de los precios y su volatilidad en los mercados internacionales.

a repercusión estimada de la crisis de los precios de 2006-08 en el número de personas subnutridas varió notablemente en función de las regiones y los países ${ }^{1}$ Los diferentes saldos comerciales netos (es decir, exportador o importador) y las diferentes respuestas en materia de políticas para hacer frente a las perturbaciones de los precios y los ingresos constituyen la clave de las diversas consecuencias que se registraron. Los países más expuestos a las fluctuaciones de los precios en los mercados internacionales eran en general los países pobres importadores de alimentos: disponían de escasas reservas y recursos presupuestarios insuficientes para adquirir alimentos a precios altos; tampoco tenían la opción de imponer restricciones a las exportaciones. Estos países fueron los principales perjudicados por la crisis ya que los precios internos de los alimentos básicos aumentaron considerablemente en sus mercados. La mayoría de ellos se encontraba en África; en la Figura 1 se reflejan estas tendencias divergentes de la subnutrición en África y Asia. Entre 2007 y 2008, el número de personas subnutridas se mantuvo básicamente constante en Asia (con un aumento del $0,1 \%$ ), mientras que se incrementó un 8 \% en África.

Las políticas comerciales -muchos países impusieron restricciones a la exportación o redujeron los obstáculos a la importación - fueron un importante factor determinante de las consecuencias de la crisis. Además de las políticas comerciales, entre las medidas más comunes adoptadas en

\section{FIGURA 1}

La subnutrición en el mundo: dos tendencias muy diferentes después de las crisis

ÁFRICA

\section{Millones}

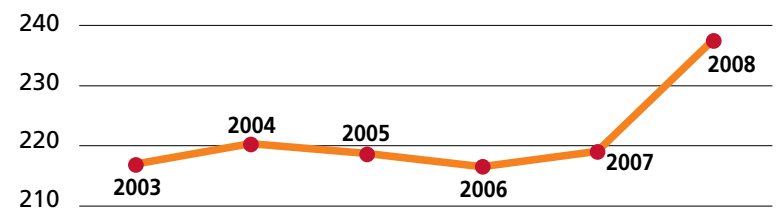

200

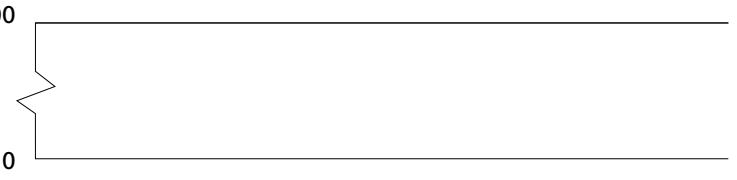

ASIA

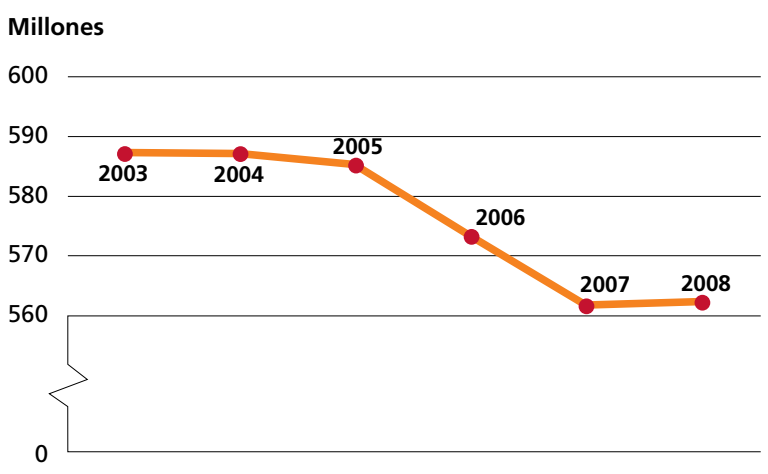


los países que trataron de contener el problema del alza de los precios de los alimentos cabe citar la puesta en circulación de las existencias públicas y la concesión de subvenciones al consumo ${ }^{2}$.

En general, cabe distinguir tres grupos principales de países que se diferencian por su capacidad para limitar las alteraciones de los precios o mitigar sus efectos. Estos se muestran en la Figura 2, en la que se refleja la situación registrada en los países con respecto a dos dimensiones, en concreto la variación porcentual de los precios reales internos de los alimentos en el período de 2007 a 2008 y la variación porcentual en el número de personas subnutridas en el período de 2006-07 a 2009. El primer grupo registró un aumento de los precios internos relativamente pequeño de 2007 a 2008, unido a progresos en la reducción de la subnutrición. Esos países se encuentran hacia la parte inferior izquierda de la figura. El segundo grupo, que se encuentra hacia la parte superior izquierda de la figura, registró un aumento de los precios internos relativamente grande, pero realizó progresos en la reducción de la subnutrición. Por último, el tercer grupo también registró un incremento de los precios internos relativamente grande, pero sumado a un aumento de la subnutrición. Estos países se encuentran en la parte superior derecha de la figura.

\section{El primer grupo de países combinó las restricciones comerciales, las redes de seguridad y la introducción de} existencias en el mercado. Ello les permitió proteger sus mercados de alimentos de las perturbaciones internacionales, pero la eficacia de esas políticas depende de los recursos necesarios disponibles para ponerlas en práctica. Incluso los programas de protección social (como los del Brasil) comportan gastos que muchos países no pueden permitirse, especialmente durante una crisis. Las restricciones a la exportación socavan los ingresos públicos y reducen las posibilidades de los agricultores de obtener beneficios

\section{FIGURA 2}

Diferencias en la capacidad de recuperación de los distintos países tras las perturbaciones de los precios de los alimentos



Notas: El tamaño de las burbujas es proporcional al número de personas subnutridas en 2008. Los países de África figuran en rojo; los de Asia, en azul; los de América Latina, en verde. Los precios utilizados son los precios al por menor —ajustados en función de la inflación_- de los alimentos básicos más importantes en los principales mercados, ponderados según la población de cada mercado y la proporción de aporte energético de cada alimento básico.

Fuente de los datos primarios: Sistema mundial de información y alerta sobre la alimentación y la agricultura (SMIA) de la FAO. 
mediante el aumento de la producción en respuesta al alza de los precios. Además, el mantenimiento de las reservas de alimentos comporta notables costos, lo cual supone que los países pobres posiblemente no tuvieran existencias disponibles antes de la crisis para compensar la disminución de la producción interna. Este primer conjunto de países, entre ellos China y la India, se agrupan en la parte inferior izquierda de la Figura 2. Lamentablemente, las restricciones a la exportación acentuaron el aumento de los precios en los mercados internacionales y agravaron los efectos de la escasez de alimentos en los países que dependen de las importaciones.

\section{El segundo grupo se benefició de los altos precios ya que la mayoría de los pobres en estos países son vendedores netos de alimentos. Sus ingresos aumentaron en general con la subida de los precios, incluso teniendo en cuenta que algunas de las ganancias se redujeron en parte por el encarecimiento de insumos tales como fertilizantes, semillas o el combustible. Estos países suelen ser exportadores netos de alimentos con una distribución relativamente equitativa de la tierra (lo que significa que hay más agricultores con excedentes disponibles para la venta). Este grupo de países, que incluye a Tailandia y Viet Nam, tienden a situarse en la parte superior izquierda de la Figura 2.}

El tercer grupo comprende los países que dependen en general de las importaciones de alimentos. Estos países estaban expuestos al alza de los precios internacionales de los productos alimenticios básicos, no disponían en general de existencias suficientes y no contaban con los recursos presupuestarios necesarios para proteger adecuadamente la seguridad alimentaria de las poblaciones pobres. Estos países fueron los más afectados por la crisis (véanse los países hacia la parte superior derecha de la Figura 2). Muchos de ellos importaron considerablemente menos de lo necesario con fines comerciales debido a la escasez de divisas, por lo que se vieron obligados a recurrir a la ayuda exterior y, en concreto, a la ayuda alimentaria. El Gobierno de Burkina Faso, por ejemplo, realizó ventas subvencionadas de cereales, pero en el año 2008 se vio obligado a recurrir al Programa Mundial de Alimentos (PMA) para la prestación de ayuda a 600000 beneficiarios (a través de la alimentación escolar y los centros de salud materna e infantil). El Gobierno de Etiopía vendió en torno a 190000 toneladas de trigo de sus reservas de cereales a unas 800000 personas pobres de zonas urbanas e importó 150000 toneladas de trigo de agosto a septiembre de 2008 para satisfacer la demanda de este cereal en las zonas urbanas, mientras que las organizaciones no gubernamentales (ONG) y el PMA canalizaron 200000 toneladas de alimentos aproximadamente a un número creciente de personas que necesitaban ayuda alimentaria.

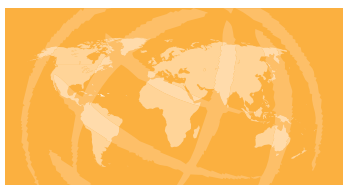

\section{Revisión de la metodología de la FAO para la medición del hambre}

El Comité de Seguridad Alimentaria Mundial (CFS), en su período de sesiones celebrado en 2010, pidió a la FAO que examinara su metodología para la estimación de la subnutrición con el fin de proporcionar más datos actualizados de forma oportuna e incorporar toda la información pertinente, incluido el análisis de un gran número de encuestas de hogares que se han puesto a disposición de los interesados en los últimos años. Por tanto, este año es de transición mientras se revisa la metodología de la FAO. Por esta razón, no figuran estimaciones actualizadas del número de personas subnutridas en 2009 y 2010 en el número de El estado de la inseguridad alimentaria en el mundo de este año; tampoco se ha realizado una estimación para 2011.

Con el fin de mejorar su metodología, la FAO realizará varios ajustes, que incluyen la estimación de cómo afectan a la subnutrición los cambios en el acceso a los alimentos debido a las variaciones en los ingresos y los precios de los alimentos. También se está trabajando para mejorar la elaboración de balances alimentarios. Se está procesando además un gran número de encuestas relativas a los gastos de los hogares con objeto de proporcionar estimaciones más precisas de la distribución del consumo de alimentos dentro de un país. Las estimaciones de la FAO sobre la subnutrición se complementarán también con varios indicadores diferentes a fin de reflejar más acertadamente la naturaleza polifacética de la inseguridad alimentaria.

El proceso de revisión de la metodología de la FAO comporta la celebración de consultas con expertos de todo el mundo. La Academia Nacional de Ciencias de los Estados Unidos de América organizó un taller en febrero de 2011 en Washington, DC en el que se formularon numerosas propuestas, así como en la mesa redonda patrocinada por el CFS que se celebró en Roma en septiembre de 2010. Además, en enero de 2012 se celebrará en Roma un Simposio científico internacional. La FAO considera que estas consultas son esenciales para seguir mejorando la metodología utilizada para la medición del hambre. 


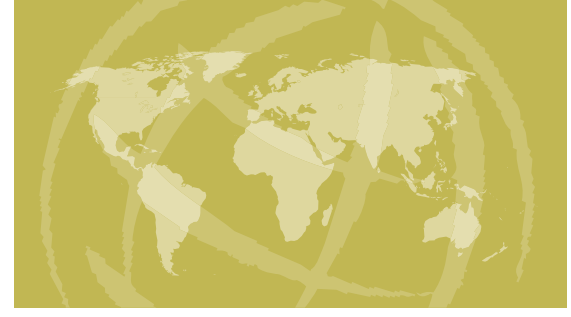

\section{Tendencias recientes en los precios mundiales de los productos alimenticios básicos: costos y beneficios}

\section{Tendencias pasadas y futuras de los precios mundiales de los alimentos}

\section{Mensaje principal}

Es probable que los precios de los alimentos sigan siendo elevados y volátiles. La demanda de los consumidores en los países con economía en rápido crecimiento aumentará, la población continúa creciendo, y si prosigue la expansión de los biocombustibles el sistema alimentario se verá sometido a demandas adicionales. En el lado de la oferta, se plantean desafíos debido a la creciente escasez de los recursos naturales en algunas regiones y a la disminución de las tasas de crecimiento de los rendimientos de algunos productos básicos. La volatilidad de los precios de los alimentos podría incrementarse debido a los vínculos más estrechos entre los mercados agrícolas y energéticos, así como a la mayor frecuencia de las perturbaciones causadas por fenómenos meteorológicos.

os precios de los productos alimenticios básicos en los mercados mundiales, ajustados en función de la inflación, disminuyeron considerablemente en el período comprendido entre el decenio de 1960 y comienzos del decenio de 2000, cuando alcanzaron un mínimo histórico (Figura 3). Subieron lentamente de 2003 a 2006 y luego sufrieron un brusco aumento entre 2006 y mediados de 2008 antes de disminuir en el segundo semestre de ese año. El aumento repentino de los precios sorprendió a muchos y suscitó una mayor preocupación sobre la capacidad de la economía alimentaria mundial para proporcionar alimentos suficientes a miles de millones de personas, ahora y en el futuro. Aunque los distintos observadores atribuyen diferentes grados de importancia a las diversas causas, existe un consenso relativamente sólido acerca de que múltiples factores influyeron en el aumento de los precios que comenzó en $2003^{3}$. Estos incluyen:

- $\quad$ perturbaciones meteorológicas como la sequía de Australia (2005-07), que redujo la producción y el comercio de trigo;
- $\quad$ las políticas dirigidas a promover la utilización de biocombustibles (aranceles, subvenciones y niveles de uso obligatorios) que aumentaron la demanda de maíz y aceites vegetales;

- la depreciación del dólar estadounidense;

- el crecimiento económico a más largo plazo en varios grandes países en desarrollo, que: a) ejerció una presión alcista sobre los precios del petróleo y los fertilizantes debido a que su crecimiento económico requería un uso intensivo de recursos y b) condujo a una mayor demanda de carne, y en consecuencia de piensos, a medida que se diversificaban los regímenes alimenticios;

- $\quad$ el aumento de los costos de producción (por ejemplo, en bombas de riego y maquinaria) y de transporte como consecuencia del incremento de los precios del petróleo y los fertilizantes;

- $\quad$ el crecimiento más lento del rendimiento (y la producción) de cereales, especialmente el arroz y el trigo, durante los últimos 20 años debido a la baja inversión en los tres decenios anteriores;

- $\quad$ el aumento de la demanda en los mercados de futuros de productos básicos como consecuencia de la especulación y de la diversificación de la cartera;

- los bajos niveles de existencias debido en parte a algunos de los factores señalados anteriormente;

- las políticas comerciales, por ejemplo prohibiciones de exportación y compras agresivas por parte de los gobiernos, que impulsaron a los productores a retener los suministros, a los proveedores a aumentar las existencias y a los consumidores a realizar compras motivadas por el pánico.

Cuando los precios bajaron en el segundo semestre de 2008, se albergó alguna esperanza de que se estabilizaran, aunque probablemente a un nivel más alto que antes de su fuerte aumento previo. Sin embargo, a mediados de 2010 comenzaron de nuevo a subir rápidamente (Figura 3). Ello 
suscitó de nuevo preocupación por los precios altos y puso en primer plano la cuestión de la volatilidad; aparentemente los precios mundiales de los productos alimenticios estarán expuestos en el futuro a reiterados altibajos.

¿Continuarán en el futuro el alza de los precios y el aumento de la volatilidad? En cuanto a los precios se refiere, numerosos modelos de proyección a largo y medio plazo sugieren que los precios de los productos alimenticios básicos seguirán siendo relativamente elevados durante el próximo decenio aproximadamente. Por ejemplo, en el número de 2011 de la publicación Perspectivas Agrícolas de la Organización para la Cooperación y el Desarrollo Económicos (OCDE) y la Organización de las Naciones Unidas para la Alimentación y la Agricultura (FAO) ${ }^{4}$ se prevé que los precios mundiales del arroz, el trigo, el maíz y las semillas oleaginosas en el lustro comprendido entre 2015-16 y 2019-20 serán un $40 \%$, un $27 \%$, un $48 \%$ y un $36 \%$ superiores en términos reales, respectivamente, en comparación con el lustro de 1998-99 a 2002-03.

RECUADRO 1

\section{FIGURA 3}

Aparte del pico registrado en el decenio de 1970, el costo

de los alimentos se redujo desde comienzos del decenio

de 1960 hasta 2002, cuando comenzó una tendencia al alza

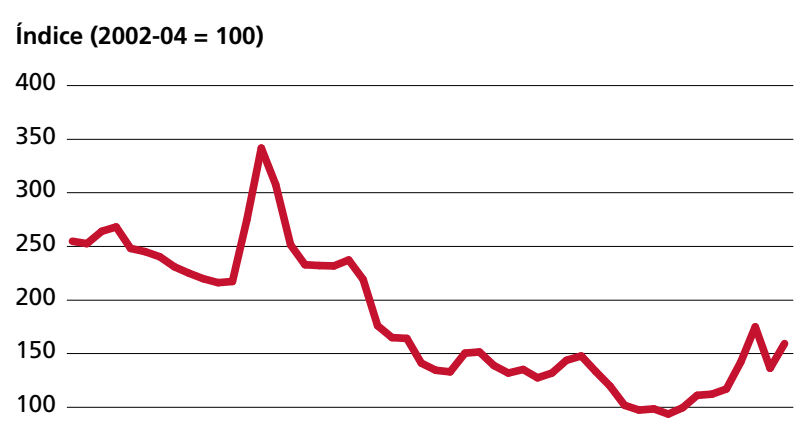

50

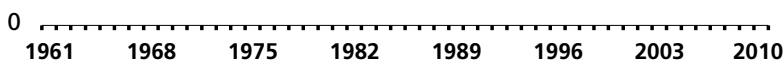

Notas: Índice de precios de los alimentos de la FAO, ajustado en función de la inflación, 1961-2010, calculado usando los precios internacionales de los cereales, las semillas oleaginosas, la carne, los productos lácteos y el azúcar. El índice oficial de precios de los alimentos de la FAO se viene calculando únicamente desde 1990; en esta figura se ha ampliado a 1961 utilizando datos aproximados sobre precios. Este índice mide las fluctuaciones de los precios internacionales, no de los precios internos. El deflactor del producto interno bruto de los Estados Unidos de América se utiliza para expresar

\section{Algunos conceptos clave: el nivel, la volatilidad (variabilidad) y la imprevisibilidad de los precios}

Al analizar los precios de los alimentos es importante distinguir entre varios conceptos relacionados entre sí, pero diferentes. En primer lugar, es fundamental diferenciar entre el nivel medio y la variabilidad (volatilidad'1') de los precios en un determinado período de tiempo. Es posible que los precios medios cambien sin que se modifique la variabilidad. Ello podría suceder fácilmente si un país importador de alimentos tuviera que imponer un arancel constante sobre las importaciones; el arancel encarecería los alimentos, pero en la mayoría de las circunstancias no tendría ningún efecto sobre la variabilidad de los precios internos. A la inversa, también es posible que se produzca un cambio en la variabilidad de los precios sin que esto afecte a su nivel medio. Tal sería el caso, por ejemplo, si el clima se volviera más variable pero el volumen promedio de la producción de alimentos siguiera siendo el mismo.

Dicho esto, los niveles de los precios y su volatilidad están relacionados entre sí, ya que ambos están determinados por la oferta y la demanda. Además, los precios altos suelen estar vinculados con una volatilidad elevada. Inicialmente, los precios altos alientan a las personas a reducir sus existencias, lo cual puede moderar las fluctuaciones de los precios que de otro modo habrían causado las crisis de la oferta y la demanda. Sin embargo, al disminuir las existencias el sistema se vuelve vulnerable a nuevas crisis de la oferta o la demanda; la ausencia de existencias reguladoras supone que la variación de los precios tenderá a ser mayor que si se contara con tales existencias. A pesar de esta relación, es importante distinguir ambos conceptos. En un caso, los precios pueden ser elevados pero estables. En el otro, los costos y los beneficios de los precios altos y de la volatilidad son muy diferentes, como se señala en los epígrafes "Costos y beneficios de los precios altos y bajos de los alimentos" y "Costos y beneficios de los precios volátiles e imprevisibles".

Es preciso asimismo distinguir entre variabilidad e imprevisibilidad. Los precios fluctúan por muchas razones, pero determinadas variaciones son, en gran medida, previsibles. El ejemplo clásico de modificación previsible de los precios de los alimentos es la variación estacional: los precios son más bajos durante la cosecha e inmediatamente después, y más elevados inmediatamente antes de la misma. Si bien las variaciones estacionales no son exactamente constantes de año en año, a menudo son similares entre un año y el siguiente. Las perturbaciones climáticas, en cambio, suelen ser imposibles de prever y pueden conducir a variaciones no pronosticables de los precios, especialmente si las existencias iniciales son bajas. Por tanto, ciertos cambios de los precios son relativamente fáciles de prever mientras que otros lo son mucho menos. Las variaciones previsibles de los precios comportan diferentes costos y beneficios con respecto a aquellas que son imprevisibles.

${ }^{1}$ Los términos "variabilidad", "inestabilidad" y "volatilidad" se utilizan como sinónimos en este informe. 
Se prevé un aumento de los precios en general debido a que el crecimiento constante de la población y de la economía ejercerá una presión alcista sobre la demanda, así como a la mayor utilización prevista de biocombustibles como consecuencia de las políticas en la materia y del precio del petróleo. En el lado de la oferta, si los precios del petróleo siguen aumentando, los costos de producción agrícola se incrementarán, lo cual contribuirá al encarecimiento de los alimentos. Las limitaciones de recursos naturales, y sobre todo el cambio climático y la escasez de tierras productivas y agua disponibles en algunas regiones, plantean importantes retos para la producción de alimentos a precios asequibles 5 . Un aspecto más positivo es que todavía existe un potencial considerable para aumentar la productividad de los cultivos mediante las nuevas tecnologías y la mejora de la extensión, así como para reducir las pérdidas en la cadena productiva. Sin embargo, estos beneficios no se materializarán sin una mayor inversión. También es posible una expansión de las tierras cultivables en África, Asia central, América Latina y Ucrania pero, una vez más, ello dependerá de una inversión adecuada. Por otra parte, la expansión de las tierras puede tener asimismo consecuencias ambientales negativas.

También hay argumentos convincentes que sugieren que, además de ser más elevados, los precios de los productos alimenticios básicos serán más volátiles en el futuro. Si aumenta la frecuencia de los fenómenos meteorológicos extremos, las crisis de la producción serán más frecuentes, lo cual contribuirá a que los precios sean más volátiles. Además, las políticas en materia de biocombustibles han establecido nuevos vínculos entre el precio del petróleo y el de los productos alimenticios básicos. Al aumentar los precios del petróleo se incrementará la demanda de biocombustibles, lo cual encarecerá los alimentos, y lo contrario cuando disminuyan los precios del petróleo ${ }^{6}$. Debido a que los precios mundiales del petróleo han sido históricamente más volátiles que los de los productos alimenticios, el mercado mundial de alimentos puede también experimentar una mayor volatilidad. La mayor participación en los mercados financieros (por ejemplo, por medio de fondos de pensiones) en los que se comercia con fondos indicadores de productos básicos podría conducir también a un aumento de la volatilidad, aunque esta cuestión se ha debatido acaloradamente sin que se haya llegado a un consenso claro al respecto.

Si bien no es posible saber con certeza en qué medida podrán aumentar los precios o su volatilidad en el futuro, los riesgos vinculados a unos precios más altos y una volatilidad mayor son lo suficientemente elevados como para justificar un esfuerzo considerable por comprender qué puede hacerse a fin de reducir la probabilidad de esos aumentos o controlar las consecuencias si son inevitables. Al examinar las opciones más adecuadas para contrarrestar los precios altos o volátiles es pertinente recordar, sin embargo, que el nivel y la volatilidad de los precios son el resultado de diversos vectores que afectan a la oferta y la demanda. Además, en este informe se hace hincapié en que las causas y los efectos de los precios elevados o volátiles son complejos porque dependen notablemente del contexto específico, es decir, el producto objeto de examen, los factores concretos que afectan a la transmisión de precios en diversas circunstancias (políticas, tipos de cambio, dependencia de las importaciones), las características demográficas de los hogares y sus modalidades de producción y consumo, así como muchas otras variables. Por tanto, un mensaje fundamental es que las intervenciones en materia de políticas deberían tener en cuenta el contexto específico en el que han de aplicarse.

RECUADRO 2

\section{Cómo medir la volatilidad de los precios}

La forma más sencilla de medir la volatilidad de los precios es por medio del coeficiente de variación (CV), esto es, la desviación estándar de los precios durante un determinado período de tiempo dividida por el precio medio durante el mismo intervalo. Una de las ventajas de esta medida es que no tiene unidades. Ello hace que sea fácil comparar, por ejemplo, la volatilidad de los precios internos estimados en diferentes países. Sin embargo, el CV puede inducir a error si los datos registran tendencias marcadas, porque sus desplazamientos se incluirán en el cálculo de la volatilidad. Por otra parte no existe ningún método aceptado universalmente para eliminar el componente de tendencia ya que diferentes observadores tendrán diversas concepciones sobre la naturaleza de la tendencia subyacente (por ejemplo, lineal o cuadrática).

Como alternativa al CV, los economistas utilizan con frecuencia la desviación estándar de las variaciones en el logaritmo de los precios ${ }^{1}$. Esta ecuación tampoco tiene unidades, pero se ve menos afectada por las tendencias marcadas a lo largo del tiempo.

${ }^{1}$ C.L. Gilbert y C.W. Morgan. 2010. Review: Food price volatility. Philosophical Transactions of the Royal Society B, 365: 3023 a 3034 


\section{Vendedores y compradores netos de alimentos}

En el plano de los hogares, los conceptos de vendedor y comprador neto de alimentos son exactamente análogos a los de exportador e importador neto de alimentos cuando se habla de países. La situación de un hogar en concreto se determina restando el valor de los alimentos que consume (incluidos los de su propia producción) del valor de los alimentos que produce ${ }^{1}$. Este cálculo tiene implícitamente en cuenta los costos de comercialización y la variación estacional, ya que utiliza los precios al productor para valorar la producción y los precios al por menor para valorar el consumo. Por ejemplo, un hogar puede ser un vendedor neto de alimentos en el período de la cosecha y un comprador neto en otros momentos. Por otra parte, un hogar podría de hecho producir anualmente más de lo que consume en términos cuantitativos y ser sin embargo, comprador neto de alimentos, si vende toda su producción durante la cosecha y vuelve a comprar en el mercado más adelante, ya que los precios al por menor son más altos que los precios al productor.

También es cierto que el hecho de que un determinado hogar sea vendedor o comprador neto de alimentos puede depender del nivel general de los precios en el mercado. Precios altos desalientan el consumo, fomentan una mayor producción y pueden llevar a que algunos hogares que son compradores netos se conviertan en vendedores netos. La disminución de los precios podría tener el efecto opuesto. No obstante, cabe señalar que esta "segunda ronda de efectos" suele tener repercusiones marginales; un hogar podría pasar de pequeño comprador neto a pequeño vendedor neto, pero no a gran vendedor neto ${ }^{2}$. De hecho, se ha señalado que este fenómeno tiene únicamente efectos menores en cuanto a la repercusión de los precios más elevados en la pobreza33.

Este método de evaluar las consecuencias de las variaciones de los precios en función de si un hogar es comprador o vendedor neto de alimentos puede utilizarse para determinar el efecto de las variaciones de los precios de los productos alimenticios, pero no los de las fluctuaciones simultáneas de los precios de los alimentos y los insumos (por ejemplo, los fertilizantes). Si los precios de los fertilizantes aumentan al mismo tiempo que los de los alimentos, los efectos netos sobre los agricultores tendrán que evaluarse a partir de datos sobre los costos de producción (para más información a este respecto, véase el epígrafe "¿Se compensa el encarecimiento de los fertilizantes con el incremento de los precios al productor?").

${ }^{1}$ N. Minot y F. Goletti. 1998. Rice export liberalization and welfare in Vietnam. American Journal of Agricultural Economics, 80(4): 738 a 749 ${ }^{2}$ Ibídem.

${ }^{3}$ A. Zezza, B. Davis, C. Azzarri, K. Covarrubias, L. Tasciotti y

G. Anríquez. 2008. The impact of rising food prices on the poor.

Documento de trabajo n. ${ }^{\circ}$ 08-07 de la ESA. FAO. Roma

(disponible en: ftp://ftp.fao.org/docrep/fao/011/aj284e/aj284e00.pdf).

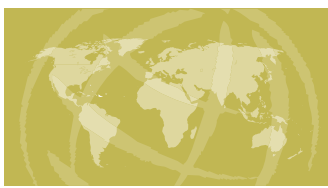

\section{Costos y beneficios de los precios altos y bajos de los alimentos}

\section{Mensaje principal}

A corto plazo, los beneficios de los precios altos van principalmente a los agricultores que disponen de un gran excedente para comercializar, y estos agricultores no son los más pobres de entre los pobres. Además, las personas más pobres suelen comprar más alimentos de los que venden. Por tanto, los precios de los alimentos suelen agravar la pobreza, la inseguridad alimentaria y la malnutrición. Sin embargo, los precios elevados representan una oportunidad para estimular la inversión a largo plazo en la agricultura, lo cual contribuirá a la seguridad alimentaria sostenible a más largo plazo.
Examinemos en primer lugar los efectos de los precios altos (o bajos). Los precios de los productos alimenticios básicos tienen dos tipos de consecuencias: en primer lugar, los precios del mercado internacional pueden influir en las variables macroeconómicas nacionales, tales como la balanza de pagos, el déficit presupuestario y los tipos de cambio, mientras que los precios internos afectan a la pobreza, el consumo calórico y la nutrición de los individuos. (Los vínculos entre los precios nacionales e internacionales se examinan en detalle en el apartado "Enseñanzas de la crisis alimentaria mundial de 2006-08".) 


\section{Efectos macroeconómicos}

Los efectos macroeconómicos de los precios de los productos básicos son importantes porque afectan a los ingresos per cápita, que en última instancia son un factor determinante del nivel de vida de las personas y de las familias.

En general, los precios elevados de los productos alimenticios básicos en el mercado internacional reportan beneficios a los países que exportan dichos productos, mientras que los precios bajos favorecen a los países importadores. Si se dejan de lado por un momento las consideraciones relativas a la volatilidad, se trata básicamente de un juego de suma cero a corto y medio plazo: los exportadores se benefician a expensas de los importadores y viceversa. A largo plazo, sin embargo, el aumento de los precios podría comportar que determinados países importadores invirtieran en la agricultura y redujeran las importaciones, o incluso que se convirtieran en exportadores. Esa inversión es esencial para el desarrollo del sector agrícola y para la reducción sostenible de la pobreza y la inseguridad alimentaria.

Los efectos en la balanza de pagos y el tipo de cambio serán mayores en los países en los que el comercio de alimentos constituye una parte fundamental de las exportaciones o de las importaciones. Los países que exportan una gran proporción de su producción se benefician más cuando los precios son elevados, mientras que aquellos que importan una gran proporción de los alimentos que consumen son los más perjudicados por los altos precios. Sin embargo, las condiciones comerciales también revisten importancia. Por ejemplo, un país que exporta petróleo o metales quizá no necesite producir una cantidad mayor de esos bienes para compensar los precios elevados de los alimentos si el precio de sus exportaciones se incrementa más que el de las importaciones de productos alimenticios.

En cuanto a los efectos fiscales, las repercusiones de los precios de los alimentos serán mayores en los países en que las subvenciones alimentarias representen una partida importante del presupuesto. Para los importadores, los costos de la subida de los precios tendrán repercusiones fiscales directas si las subvenciones no solo se mantienen sino que se incrementan para contrarrestar los aumentos de los precios. Por otra parte, incluso en los países exportadores que subvencionan el consumo interno habrá importantes consecuencias en cuanto a los costos de oportunidad. En ambos casos, las subvenciones elevadas pueden reducir los fondos disponibles para la inversión en bienes públicos como la investigación agrícola, la educación, la salud y las carreteras. La disminución del gasto en estas áreas puede reducir a largo plazo el crecimiento económico, como ha sucedido de hecho en América Latina ${ }^{7}$.

\section{Repercusiones para los hogares}

Las poblaciones pobres gastan la gran mayoría de sus ingresos en productos alimenticios (Figura 4), mientras que

FIGURA 4

80

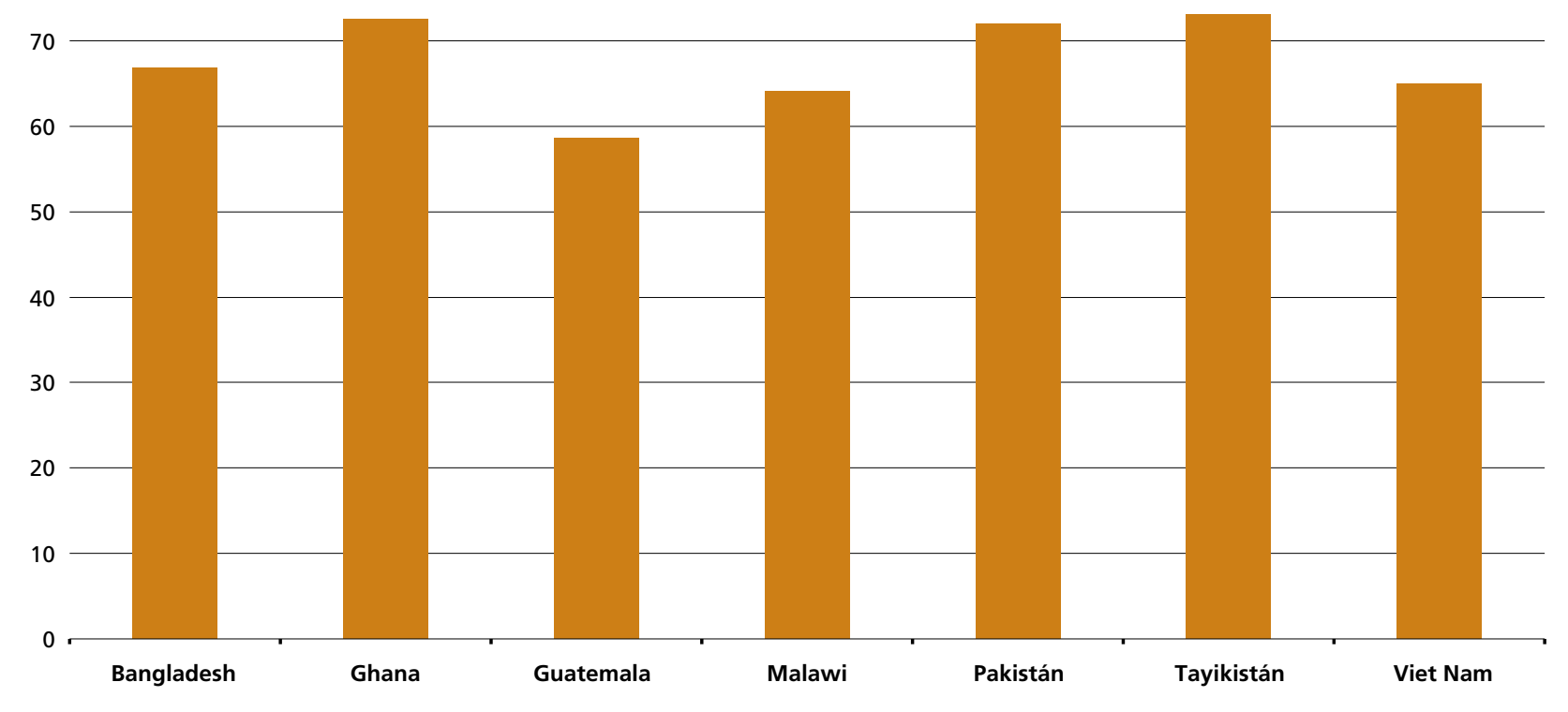

Nota: Porcentaje del presupuesto de los hogares destinado a la compra de alimentos por el quintil de la población con menores gastos.

Fuente de los datos primarios: Proyecto de la FAO sobre actividades generadoras de ingreso rural. 
muchos agricultores obtienen una parte considerable de sus ingresos de la producción de alimentos. Esto hace pensar que las variaciones de los precios de los alimentos tendrán notables consecuencias en el bienestar de los agricultores y los consumidores más pobres.

Con objeto de comprender la importancia de los precios de los alimentos para el bienestar, la pobreza y la seguridad alimentaria, es pertinente distinguir entre vendedores y compradores netos de alimentos. Un vendedor neto de alimentos es alguien para quien el valor total de los alimentos que produce excede el valor total de los que consume, mientras que para un comprador neto de alimentos ocurre lo contrario. Los compradores netos de alimentos en general se verán afectados por el encarecimiento de los alimentos, mientras que los vendedores netos de alimentos se beneficiarán de él (véase el Recuadro 4).

Los conceptos de vendedor y comprador neto de alimentos se distinguen claramente de los de hogar rural o urbano. Casi todos los habitantes de las zonas urbanas son compradores netos de alimentos; lo que tal vez resulte sorprendente es que también lo sea la mayoría de los habitantes de las zonas rurales. Los productores y los agricultores a escala muy pequeña suelen ser compradores netos de alimentos ya que no producen lo suficiente para sus familias. Por tanto, tienen que comprar los alimentos en el mercado, de manera que es probable que se beneficien de los precios más bajos (véase más adelante, sin embargo, el examen de los posibles efectos del incremento de los precios de los alimentos en los salarios rurales, que suelen ser una fuente importante de ingresos para los campesinos sin tierra). Los hogares rurales sin tierras o que poseen tierras escasas son los más pobres de entre los pobres, y un porcentaje desproporcionado de ellos está encabezado por mujeres.

En las zonas urbanas, la subida de los precios de los alimentos puede perjudicar notablemente a los pobres

RECUADRO 4

\section{Los bosques y la seguridad alimentaria}

La superficie forestal mundial es aproximadamente de 4000 millones de hectáreas, y aún representa alrededor del $30 \%$ de la superficie total de tierras de nuestro planeta ${ }^{1}$. Es sabido que los bosques proporcionan numerosos servicios ambientales indispensables, ya que contribuyen a la gestión del agua y a conservar la biodiversidad y sirven de sumidero de carbono para mitigar el recalentamiento mundial. Además, los bosques desempeñan un papel importante en la seguridad alimentaria de 1000 millones de entre los habitantes más pobres del planeta, al proporcionar alimentos o ingresos en efectivo a través de una vasta gama de productos como los ñames silvestres, la carne de caza, los insectos comestibles, frutos, hojas, setas, nueces, miel y productos medicinales. Los bosques proporcionan además numerosas materias primas no alimentarias, como el bambú, el rotén, las fibras de palma y resinas, que pueden utilizarse para la construcción de refugios, ser vendidas en los mercados locales o destinarse a forraje para el ganado².

Las personas cuya seguridad alimentaria depende de los bosques son a menudo muy vulnerables al aumento de los precios de los alimentos porque adquieren en el mercado la mayor parte de los alimentos que consumen. Para estos grupos que viven de la recolección y de la caza, el incremento de los precios de los alimentos significa que deben extraer más productos de los bosques ya sea para venderlos en los mercados locales (a fin de obtener dinero suficiente para comprar esos alimentos más caros) o para intercambiarlos mediante trueque. Los precios alimentarios más altos pueden por eso tener un efecto directo en la calidad de los bosques, así como en la conservación y la supervivencia de especies forestales fundamentales (principalmente de fauna y plantas medicinales).

Para esas personas, el cultivo no constituye una alternativa, ya que no poseen tierras cultivables ni tienen acceso a ellas. En vista de las preocupaciones sobre el cambio climático y las pérdidas de biodiversidad, recurrir a nuevos desmontes tampoco constituiría una alternativa atractiva. Así pues, la gestión forestal sostenible es fundamental para su seguridad alimentaria. Cada vez más se necesitará la gestión de los bosques no solamente en función de su producción maderera, sino también a fin de obtener un suministro mayor y más sostenible de productos forestales comestibles no madereros y de potenciar los numerosos servicios que bosques y árboles proporcionan al sector agrícola.

\footnotetext{
${ }^{1}$ FAO. 2010. Evaluación de los recursos forestales mundiales 2010. Roma.
} 2 Para más información, véase http://www.fao.org/forestry/nwfp/es/. 
ya que, por lo general, en ellas se producen escasos alimentos y estos suelen representar una gran proporción de los gastos de los pobres. Con objeto de hacer frente a la reducción de la renta disponible como resultado del encarecimiento de los alimentos, las familias emprenden nuevas actividades económicas, venden activos o se endeudan con el fin de mitigar la disminución del consumo. También suelen reducir los gastos en salud y educación, además de cambiar sus pautas alimentarias para pasar a productos más baratos (amiláceos), abandonando alimentos ricos en micronutrientes tales como la leche, la carne o las frutas y hortalizas ${ }^{8}$. También se reducirá el aporte calórico en los casos en que las personas son tan pobres que no pueden permitirse la misma cantidad de calorías a los nuevos precios más elevados.

En las zonas rurales el incremento de los precios de los productos alimenticios suele tener menores efectos negativos en los compradores netos de alimentos, puesto que numerosos hogares producen una parte importante de lo que consumen y, por tanto, solo son compradores de alimentos en medida marginal. Por otro lado, los agricultores que son vendedores netos de alimentos probablemente se beneficiarán de la subida de los precios que, en igualdad de las demás condiciones, tenderá a acrecentar sus ingresos. Habida cuenta de que muchos agricultores son pobres, el aumento de los precios podría coadyuvar a reducir la pobreza y a mejorar la seguridad alimentaria. Sin embargo, hay que tener en cuenta también que los agricultores con más excedentes de producción para vender se beneficiarán en mayor medida de los precios altos que los que solo disponen de un excedente pequeño. Además, en la mayoría de los contextos (aunque no en todos), los agricultores con más tierras suelen gozar de una mejor situación económica que aquellos que disponen únicamente de una pequeña parcela, por lo que puede suceder que los agricultores más pobres no reciban la mayor parte de los beneficios de unos precios más elevados de los alimentos. En general es más probable que los precios de los alimentos elevados tengan efectos beneficiosos en la pobreza en países con una distribución relativamente equitativa de la tierra.

Otro posible efecto importante de los precios de los alimentos sobre la pobreza y la seguridad alimentaria tiene lugar a través del mercado laboral y los salarios. El alza de los precios de los alimentos estimula la demanda de mano de obra no cualificada para trabajar en las explotaciones agrícolas, lo cual podría redundar en un aumento de los salarios rurales a largo plazo. Ello beneficiaría a los hogares cuyos ingresos dependen del trabajo asalariado (que suelen ser muy pobres). Sin embargo, los datos de que se dispone en este sentido no son concluyentes, y dependen de la importancia de la agricultura en la economía en general y de cuántos años tardan en realizarse los ajustes salariales ${ }^{9}$. El canal del mercado laboral merece un estudio en mayor profundidad, ya que se dispone de poca información respecto de sus efectos en la pobreza y la seguridad alimentaria.

Teniendo en cuenta estas consideraciones, ¿qué muestran los datos sobre las repercusiones de los precios elevados en la pobreza? Los ingresos promedio de los compradores netos de alimentos son mayores que los de los vendedores netos de alimentos en la mayoría de los países en desarrollo; por consiguiente, los precios elevados de los productos alimenticios transferirían beneficios de las personas con una renta superior a aquellas con ingresos inferiores ${ }^{10}$. Sin embargo, se llega a esta conclusión al dividir la población en dos grupos únicamente: los estudios que utilizan un desglose de datos más detallado casi siempre muestran que el $20 \%$ más pobre de la población es comprador neto de alimentos, mientras que los agricultores que cuentan con excedentes se encontrarían en un lugar intermedio de la distribución de los ingresos. Por ejemplo, los precios más elevados de los alimentos incrementaron la pobreza en siete de los nueve países estudiados, a excepción únicamente del Perú y Viet Nam¹1. Este último país es un exportador importante de arroz con una distribución relativamente equitativa de la tierra; por ello, numerosos hogares vietnamitas producen un excedente de arroz pese a ser, de todas formas, relativamente pobres. En el Perú, las repercusiones beneficiosas fueron muy escasas. En todos los demás países de la muestra (Bolivia, Camboya, Madagascar, Malawi, Nicaragua, el Pakistán y Zambia), la subida de los precios aumentó la pobreza, aun tomando en consideración la mayor demanda de mano de obra. Otro estudio llegó a conclusiones similares: los pobres se vieron perjudicados por los precios más elevados en todos los países estudiados (Albania, Bangladesh, Ghana, Guatemala, Malawi, Nepal, Nicaragua, el Pakistán, Panamá, Tayikistán y Viet Nam), a excepción de los habitantes de las zonas rurales de Viet $\mathrm{Nam}^{12}$. Este estudio, que no examinó los efectos en el mercado laboral pero tomó en cuenta las respuestas de la oferta y la demanda, llegó a la conclusión de que los precios altos de todas formas perjudicaban a los pobres. El alza de los precios también agravó la pobreza en Guatemala, Honduras, Nicaragua y el Perú ${ }^{13}$. Un examen de numerosos estudios relacionados con el arroz (que incluyen a Indonesia, Filipinas y Tailandia) observó que el quintil más pobre de la población era casi siempre comprador neto de arroz ${ }^{14}$. En conjunto, estos estudios muestran que el $20 \%$ más 
pobre de la población es vendedor neto de alimentos solo en circunstancias excepcionales ${ }^{15}$.

Diferentes tipos de estudios refuerzan aún más la idea de que los precios de los alimentos perjudican a los pobres de diversas formas, y no solo situándolos por debajo del umbral de la pobreza. En términos generales, el aporte calórico se ve menos afectado que la diversidad de la alimentación y el consumo de proteínas y micronutrientes. A modo de ejemplo, cuando los precios del arroz aumentaron en Indonesia durante la crisis financiera asiática de finales del decenio de 1990, los hogares redujeron las compras de alimentos más nutritivos, como huevos y hortalizas verdes, para poder seguir adquiriendo arroz ${ }^{16}$. Esto llevó a un descenso apreciable de los niveles de hemoglobina en la sangre de los niños pequeños (y de sus madres), lo cual incrementó la probabilidad de que sufrieran daños en su desarrollo. Además, las madres de familias pobres respondieron reduciendo su ingesta calórica para alimentar más adecuadamente a sus hijos, lo cual condujo a un mayor debilitamiento materno. También se observó una correlación negativa entre los precios del arroz y el estado nutricional en Bangladesh ${ }^{17}$. La altura por edad entre los niños menores de tres años en El Salvador se redujo durante la crisis alimentaria de 2006-08, aunque este efecto se mitigó en cierta medida en el caso de las familias con acceso a remesas de emigrantes en el extranjero ${ }^{18}$. El peso para la edad no disminuyó, lo cual sugiere que se redujo el consumo de nutrientes esenciales, pero no el aporte energético. En algunas situaciones, sin embargo, puede disminuir incluso el aporte energético, además de la diversidad de la alimentación ${ }^{19}$.

Además, el encarecimiento de los alimentos parece tener un efecto negativo desproporcionado en los hogares que están a cargo de una mujer, por dos razones ${ }^{20}$. En primer lugar, estos hogares suelen tener menos acceso a tierras y otros recursos, a menudo debido al derecho consuetudinario y la discriminación social y, por consiguiente, son menos propensos a ser vendedores netos de alimentos. En segundo lugar, estas familias suelen ser también más pobres, lo que significa que gastan una mayor proporción de sus ingresos en alimentos y se ven más perjudicadas por los precios elevados.

Además de afectar a los distintos tipos de hogares de manera diferente, las variaciones de los precios de los alimentos influyen también en los diversos miembros del hogar de forma desigual. Por ejemplo, la tasa de actividad femenina puede aumentar considerablemente durante las crisis económicas ${ }^{21}$, por ejemplo en los casos en que los hombres emigran en busca de un empleo mejor ${ }^{22}$. La carga de trabajo adicional resultante restringe el tiempo de que las mujeres disponen para realizar el trabajo doméstico y atender a los niños ${ }^{23}$. Además, la mortalidad de las niñas lactantes también aumenta más que la de los varones durante las crisis $^{24}$.

Si bien los precios de los alimentos perjudican a los pobres en la mayoría de los casos, ello no es un argumento a favor de subvenciones generalizadas a los mismos. Esas subvenciones son a menudo difíciles de retirar desde el punto de vista político y pueden agotar los fondos presupuestarios del Estado que se necesitan para invertir en bienes públicos como la investigación agrícola, los caminos rurales, la educación, la salud y el saneamiento. Las subvenciones generalizadas a los precios también suelen ser en general regresivas, en el sentido de que la mayor parte de sus beneficios recaen en personas acomodadas que, a pesar de gastar una parte menor de su presupuesto en alimentos con respecto a los pobres, emplean en total comparativamente más dinero para adquirirlos.

Ahora bien, si las subvenciones generales no son la respuesta, ¿cuál es la manera más acertada de ayudar a mitigar los efectos negativos del encarecimiento de los alimentos? A corto plazo, una opción es dirigir las redes de seguridad a las personas más vulnerables (véase el epígrafe "Cómo hacer frente a la volatilidad de los precios cuando ya existe: redes de seguridad selectivas y reservas alimentarias de emergencia", página 44). A largo plazo, la mejor manera de bajar los precios de los alimentos es invertir en la agricultura; esta medida aumentará los rendimientos de manera sostenible, reducirá los costos de los insumos, incrementará la productividad y disminuirá las pérdidas y el desperdicio de alimentos. Estas inversiones pueden contribuir a que los alimentos sean más asequibles para los consumidores y más rentables para los agricultores, y constituyen la única forma de controlar los precios de los alimentos en beneficio de todos. En este sentido el remedio para los precios elevados pueden ser los precios elevados, a condición de que incentiven a los agricultores a adoptar mejores tecnologías y a los gobiernos nacionales, así como a los donantes internacionales, a incrementar los recursos financieros disponibles para la inversión en la agricultura (véase el epígrafe "Cómo prevenir la volatilidad de los precios a largo plazo: incremento de la productividad, la sostenibilidad y la capacidad de resistencia de la agricultura", página 47). Por tanto, si bien los precios altos hacen que el problema de la inseguridad alimentaria y la pobreza se agrave a corto plazo, brindan asimismo una oportunidad para la inversión y el crecimiento que puede reducir la inseguridad alimentaria y la pobreza a largo plazo. 

los precios bajos?

Antes de las últimas crisis financiera y alimentaria mundiales, numerosos observadores lamentaban que los precios mundiales de los alimentos fueran bajos y los señalaban como un problema para las poblaciones pobres de los países en desarrollo. Más recientemente, sin embargo, después del alza repentina de los precios de los alimentos, en la mayoría de los análisis se afirma que dichos precios más altos aumentan la pobreza. Ahora bien, ¿cómo es posible que tanto los precios altos como los precios bajos agraven la pobreza? ${ }^{1}$

Una vía posible para conciliar estos puntos de vista divergentes sobre los precios altos y bajos sería distinguir entre los efectos de los precios a corto y largo plazo. A corto plazo, el alza de los precios agrava la pobreza porque en la mayoría de los países el 20 \% más pobre de la población es comprador neto de alimentos. No obstante, si aumenta la inversión pública y privada a largo plazo como consecuencia de los precios más elevados de los alimentos, la mayor inversión puede incrementar la productividad y contribuir al crecimiento económico y la reducción de la pobreza. Sin embargo, ese resultado beneficioso no se derivará de una respuesta de la oferta a corto plazo resultante de una mayor utilización de mano de obra y insumos básicos tales como fertilizantes y plaguicidas.

Otra cuestión que hay que tomar en cuenta es que muchos de los beneficios del incremento de los precios mundiales irían a los grandes propietarios de tierras de países exportadores de ingresos medianos altos, pero esos agricultores no son pobres. Por tanto, incluso si los países en desarrollo se benefician de unos precios más altos, ello no quiere decir que la pobreza se reduzca; se requiere un análisis más desglosado, que examine las consecuencias para el valor de la tierra y los salarios en países concretos, así como un cuidadoso desglose de los patrones de gastos por grupo de ingresos.

También es importante tener en cuenta que la disponibilidad y el análisis de datos de encuestas por hogares se han incrementado notablemente en los últimos años y esto ha contribuido en parte al cambio de perspectiva con respecto a los precios altos y bajos. Además, algunas de las inquietudes relativas a los precios altos y bajos pueden describirse con mayor exactitud como preocupaciones por la volatilidad de los precios, ya que las

fluctuaciones marcadas de estos pueden

perjudicar tanto a los agricultores

como a los consumidores (véase más adelante el epígrafe "Costos y beneficios de los precios volátiles e imprevisibles").

Algunos estudios parecen respaldar la idea de que el aumento de los precios tiene efectos beneficiosos puesto que muestran, por ejemplo, que la liberalización del comercio agrícola reduciría la pobreza y aumentaría los precios mundiales de los alimentos. No obstante, una lectura atenta de algunos de estos estudios ${ }^{2}$ revela un cuadro con más matices. En primer lugar, lo que reduce la pobreza es el mayor acceso a los mercados protegidos, no el aumento de los precios mundiales de los alimentos ${ }^{3}$. En segundo lugar, el aumento de los precios mundiales no significa necesariamente que los precios internos sean más elevados, y es esto último lo que afecta a las tasas de pobreza. Por consiguiente, una reducción de los obstáculos a la importación causaría una baja de los precios internos y al mismo tiempo un alza de los precios mundiales (por la mayor demanda de importaciones). Los precios internos más bajos reducirían la pobreza aunque hubieran aumentado los precios mundiales. En otras palabras, el incremento de los precios agrícolas mundiales y la reducción de la pobreza son dos resultados distintos de la liberalización del comercio; los precios elevados de los alimentos no reducen la pobreza.

\footnotetext{
1 D. Rodrik. 2008. Food prices and poverty? Confusion or obfuscation? (disponible en: http://rodrik.typepad.com/dani_rodriks_ weblog/2008/05/food-prices-and.html); J. Swinnen. 2010. The right price of food: reflections on the political economy of policy analysis and communication. Documento de debate n. ${ }^{\circ} 259$ de LICOS Centre for Institutions and Economic Performance, Katholieke Universiteit Leuven. Lovaina (Bélgica).

${ }^{2}$ Véase, por ejemplo, T.W. Hertel, R. Keeney, M. Ivanic y L.A. Winters. 2006. Distributional effects of WTO agricultural reforms in rich and poor countries. Documento de trabajo sobre investigaciones relativas a las políticas $n .{ }^{\circ} 4060$ del Banco Mundial. Washington, DC, Banco Mundial.

${ }^{3}$ T.W. Hertel y W. Martin. 2008. Response to Dani Rodrik's blog post entitled 'Food prices and poverty? Confusion or obfuscation?

(disponible en: http://rodrik.typepad.com/dani_rodriks_ weblog/2008/05/food-prices-and.html).
} 


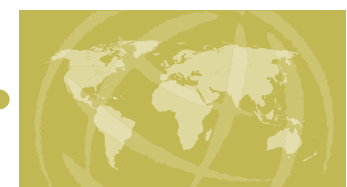

\section{Costos y beneficios de los precios volátiles e imprevisibles}

\section{Mensaje principal}

Cuando los precios fluctúan considerablemente, incluso si son tolerables en promedio, las crisis a corto plazo hacen que tanto los pequeños agricultores como los consumidores pobres sean vulnerables a las trampas de la pobreza a largo plazo. Además los pequeños agricultores tienen dificultades para invertir cuando las variaciones de los precios son imprevisibles.

A las repercusiones de los precios altos o bajos de los alimentos examinadas anteriormente se suma el hecho de que la variabilidad de los precios de los alimentos puede tener efectos importantes incluso si el precio medio se mantiene constante. Esto puede ocurrir cuando las fluctuaciones en la producción de alimentos se vuelven más frecuentes o mayores pero la producción media sigue siendo la misma. Ello daría lugar a variaciones de los precios más frecuentes y significativas, las cuales pueden ser previsibles o imprevisibles. Si el aumento de la variabilidad fuera en gran medida previsible, causaría menos problemas que unos cambios imprevisibles. Sin embargo, las variaciones de los precios en general son menos previsibles de lo que cabría suponer. Por ejemplo, incluso en el caso de la variación estacional que es el ejemplo clásico de fluctuación previsible de los precios de los alimentos, el mes con los precios más altos y más bajos puede variar considerablemente de un año a otro ${ }^{25}$. Además, incluso las variaciones completamente previsibles de los precios pueden causar problemas a los hogares pobres que no están en condiciones de tomar dinero prestado cuando los precios son elevados y, por tanto, no son capaces de "armonizar" su consumo a lo largo del tiempo. Por consiguiente, en Asia, donde las variaciones estacionales de los precios son relativamente más previsibles que en África, existe de todas formas una preocupación generalizada respecto de la capacidad de los hogares pobres para hacer frente a dichas variaciones durante el período de escasez inmediatamente anterior a la cosecha, a pesar de que ese período es sumamente previsible. Por tanto, aunque el tema central del resto de esta sección sean las fluctuaciones imprevisibles de los precios, cabe señalar que las variaciones previsibles también pueden suponer costos considerables para los pobres.

Antes de examinar algunos de los efectos negativos de la volatilidad de los precios puede ser útil señalar que, al menos en teoría y en algunas circunstancias, los precios volátiles podrían beneficiar de hecho a determinadas personas incluso si sus variaciones no son previsibles. Por ejemplo, los consumidores ricos, que pueden comprar grandes cantidades de alimentos cuando los precios son reducidos y almacenarlos para su utilización posterior, están en condiciones de comprar más productos alimenticios cuando los precios son bajos y menos cuando los precios son altos, pagando así en promedio un precio menor. Otro ejemplo serían las personas que pueden permitirse adquirir los activos que los hogares más pobres venden a precios muy bajos cuando están desesperados por encontrar fondos, o ante desastres naturales como la sequía ${ }^{26}$. En general, sin embargo, los costos de los precios inestables e imprevisibles parecerían exceder con creces este tipo de beneficios, especialmente para los pobres que sufren inseguridad alimentaria.

En términos generales, las fluctuaciones imprevisibles de los precios tienen cuatro tipos de consecuencias negativas como mínimo: las trampas de la pobreza y la reducción de las inversiones en las explotaciones agrícolas en el plano microeconómico; efectos macroeconómicos; y repercusiones sobre los procesos políticos (véase el Cuadro 1). Este informe se centra en los efectos microeconómicos para los hogares ${ }^{27}$.

\section{Trampas de la pobreza}

La mayor imprevisibilidad de los precios se traducirá en más coyunturas de precios elevados, aunque habrá también más episodios de precios bajos si el precio medio sigue siendo el mismo. Sin embargo, hay situaciones en que los períodos de precios elevados pueden tener, para los compradores netos de alimentos, consecuencias que los períodos de precios reducidos no logran revertir. Del mismo modo, los períodos de precios bajos pueden tener efectos negativos en las familias de agricultores que no se revierten por períodos de precios altos. Por ejemplo, si los precios de los alimentos básicos aumentan bruscamente durante los primeros 1000 días de vida de un niño, su consumo de los alimentos más nutritivos puede reducirse. Ello puede causar daños permanentes en la salud y el bienestar nutricional del niño y redundar, en consecuencia, en una menor productividad en la edad adulta. Una nutrición que no llegue a ser óptima puede asimismo determinar una mayor vulnerabilidad al $\mathrm{VIH}-\mathrm{SIDA}{ }^{28}$. En los casos mencionados, un período posterior de precios bajos no reparará el daño. En cuanto a los vendedores netos de alimentos, los períodos de precios bajos reducirán temporalmente sus ingresos provocando efectos similares a los registrados por los compradores netos de alimentos durante los períodos de precios altos. En esos casos, los efectos no se revertirán por un período posterior de precios elevados. 


\section{CUADRO 1}

Efectos de la volatilidad de los precios

\begin{tabular}{|c|c|c|}
\hline Canal & ¿A quién o a qué afecta? & Ejemplos \\
\hline Trampas de la pobreza & Consumidores y agricultores & $\begin{array}{l}\text { Mecanismos de adaptación temporales tales como } \\
\text { la venta de activos en condiciones desfavorables o } \\
\text { una reducción del consumo de alimentos nutritivos } \\
\text { que puede tener efectos permanentes }\end{array}$ \\
\hline $\begin{array}{l}\text { Escasa inversión privada } \\
\text { en las explotaciones agrícolas }\end{array}$ & Agricultores & $\begin{array}{l}\text { El menor uso de fertilizantes conduce a una } \\
\text { productividad más baja }\end{array}$ \\
\hline Efectos macroeconómicos & $\begin{array}{l}\text { La volatilidad de los precios de los alimentos } \\
\text { reduce la capacidad de los precios para actuar } \\
\text { como señal que orienta la asignación de recursos }\end{array}$ & $\begin{array}{l}\text { La inversión no se dirige a los sectores óptimos de } \\
\text { la economía, con lo que se reduce el crecimiento } \\
\text { económico }\end{array}$ \\
\hline Procesos políticos & $\begin{array}{l}\text { Instituciones democráticas; } \\
\text { crecimiento económico a largo plazo }\end{array}$ & $\begin{array}{l}\text { Disturbios provocados por la escasez de alimentos } \\
\text { que afectan al clima de inversión; subvenciones } \\
\text { que impiden la inversión en bienes públicos }\end{array}$ \\
\hline
\end{tabular}

La disminución temporal de la renta disponible debido a las crisis de precios puede también llevar a las familias a reducir su capital. Por ejemplo, los hogares pueden realizar ventas de tierras o ganado en condiciones desfavorables a fin de mantener su consumo de alimentos frente a una conmoción económica, aunque esto dependerá de la situación: en Burkina Faso, por ejemplo, durante una grave sequía los hogares recortaron el consumo en lugar de vender su ganado ${ }^{29}$. Otra posibilidad es que las familias realicen menos visitas al médico o retiren a los niños de la escuela con el fin de ahorrar en gastos escolares. En Burkina Faso, la matrícula escolar se ve afectada negativamente por perturbaciones como la sequía; la crisis de precios del cacao provocó consecuencias similares en Côte d'Ivoire ${ }^{30}$.

En Nicaragua, en las zonas afectadas por el huracán Mitch en 1998 los niños enfermos realizaron menos visitas al médico que los de las zonas no afectadas ${ }^{31}$. Estas respuestas pueden redundar en una pérdida de capital humano en los hogares afectados.

Tales situaciones pueden conducir a trampas de la pobreza que comportan que una perturbación que se produce una vez tenga, sin embargo, efectos permanentes. Las trampas de la pobreza pueden ser causadas por una gran variedad de factores: desastres naturales como huracanes o sequías; la desaceleración económica; o conmociones adversas de los precios. Independientemente de la causa última, cualquier factor que socave el poder adquisitivo de los pobres puede tener efectos similares.

Durante la sequía de Zimbabwe de mediados del decenio de 1990, los niños pequeños que vivían en los hogares más pobres acusaron una reducción sustancial de la tasa de crecimiento; varios años más tarde esos niños eran más bajos de lo que hubiera cabido esperar en otras circunstancias ${ }^{32}$. Estos efectos son especialmente preocupantes porque existe una amplia bibliografía que sugiere que el retraso del crecimiento se asocia a una disminución de la capacidad cognitiva y al progreso escolar más lento durante la niñez, así como a la reducción de los ingresos en la edad adulta ${ }^{33}$. En Indonesia, la disminución de las precipitaciones en el año del nacimiento redujo significativamente la altura alcanzada en la edad adulta por las mujeres y su número de años de escolaridad, así como sus ingresos en la edad adulta; condujo asimismo a una salud más deficiente en la edad adulta ${ }^{34}$. Existen datos sobre análogas trampas de la pobreza generadas por la sequía en Etiopía y por un huracán en Honduras $^{35}$. Lo que todos esos estudios tienen en común es que muestran cómo una perturbación no recurrente puede tener efectos permanentes.

\section{Reducción de las inversiones en las explotaciones agrícolas}

El segundo tipo de efectos negativos de la imprevisibilidad de los precios se refiere a las decisiones sobre la inversión en las explotaciones agrícolas adoptadas en países en desarrollo donde los mercados crediticios no funcionan adecuadamente y los ingresos son muy fluctuantes debido a las condiciones de variabilidad del clima o a la volatilidad de los precios. Si los agricultores no pueden obtener crédito cuando lo necesitan se mostrarán reacios a hacer inversiones productivas ${ }^{36}$, especialmente aquellas que vinculan el capital por períodos prolongados de tiempo. Ello puede suceder aun cuando los precios son estables, pero la volatilidad de los mismos agravará ese efecto. Por ejemplo, en la India, los agricultores no invierten lo suficiente en bueyes debido a la volatilidad de sus ingresos ${ }^{37}$. Otras decisiones fundamentales, como la elección de los cultivos, también pueden ser influenciadas por la volatilidad de los precios; tal fue el caso de los agricultores pobres en la región pakistaní del Punjab, que pasaron del cultivo de arroz Basmati, que es relativamente rentable, al de forraje para ganado en un esfuerzo por evitar los riesgos asociados con los precios (y los rendimientos) ${ }^{38}$. Incluso las inversiones en la utilización de fertilizantes, que ofrecen rendimientos a un plazo relativamente corto, parecen verse afectadas negativamente en determinadas situaciones; por ejemplo, en Etiopía los agricultores se muestran reacios a invertir en dichos productos por temor a verse afectados por una crisis económica ${ }^{39}$. 
Debido al temor a que una crisis de precios adversa pueda llevarles al tipo de trampa de la pobreza que se ha mencionado anteriormente, los pequeños agricultores pobres pueden ser reacios a adoptar las tecnologías que proporcionan una mayor rentabilidad a largo plazo. Por tanto, adoptan una estrategia de bajo riesgo y rendimientos reducidos que puede parecer óptima considerando su aversión al riesgo (la cual se debe, al menos parcialmente, a su pobreza), pero que ralentiza el proceso de desarrollo a largo plazo. Del mismo modo, puesto que gran parte de la inversión es irreversible o comporta costos no recuperables, los inversores tienden a reducirla en un entorno de precios muy imprevisibles.

\section{La volatilidad de los precios de los alimentos básicos en los países en desarrollo es particularmente perjudicial}

Es probable que la inestabilidad de los precios de los alimentos básicos tenga mayores efectos negativos que la inestabilidad de los precios de otros productos básicos agrícolas, ya que los alimentos básicos son importantes tanto para los agricultores pobres como para los consumidores pobres. Desde la óptica de los consumidores, los alimentos básicos representan una gran proporción del gasto de los pobres. Desde la de los productores, se trata de los cultivos que más se plantan en los países en desarrollo, especialmente en las pequeñas explotaciones.

Entre los alimentos básicos típicos cabe citar el arroz, el trigo, el maíz, el mijo, la yuca y la papa, aunque puede haber otros cultivos que también se consideren básicos (como las cebollas en la India o el chile en Indonesia). La proporción del presupuesto familiar que se destina a estas especias es mucho menor que la de cereales y tubérculos pero sus precios están expuestos a fluctuaciones mucho mayores, por lo que las consecuencias sobre la renta disponible pueden ser considerablemente más significativas. En cambio, en el caso de la mayoría de los cultivos comerciales (como el café o el cacao) los precios inestables tienen escasos efectos en los consumidores de los países en desarrollo. Si bien cultivos perennes como la palma de aceite constituyen productos básicos, la parte del presupuesto destinada a los mismos es mucho menor que la de que se destina a los alimentos de primera necesidad (alimentos básicos). Esto no quiere decir que la volatilidad de los precios de dichos cultivos no revista importancia para el bienestar de los pobres, sino solo que es probable que tenga menos peso que la de los precios de los alimentos básicos.

También es posible que la inestabilidad de los precios de los alimentos básicos tenga más repercusiones en países de ingresos muy bajos que en los de ingresos más altos, así como en los hogares pobres respecto a otros más acomodados, en las cuatro dimensiones del Cuadro 1. Cabría aducir dos razones principales para ello. En primer lugar, en los países pobres los alimentos representan una proporción mayor del gasto de los consumidores, de la producción agrícola y de la macroeconomía y, por tanto, tienen más repercusiones en los procesos políticos que en los países ricos. En segundo lugar, los pobres disponen de menos activos que los ricos, por lo que están en peores condiciones para evitar la volatilidad de los precios o hacer frente a ella. El corolario es que, a medida que las economías crecen y se desarrollan, la estabilidad de los precios de los alimentos es cada vez menos importante para la inversión y el crecimiento: los consumidores diversifican sus regímenes alimenticios, los productores pasan a producir cultivos de mayor valor $y$, a medida que las familias dejan las explotaciones agrícolas, la macroeconomía se diversifica.

Pero el hecho de que los costos de la inestabilidad de los precios sean mayores que sus beneficios no implica necesariamente que esta deba reducirse. Antes de afirmar tal cosa es preciso comparar los costos de los precios inestables e imprevisibles con los de la disminución de la inestabilidad o la mitigación de sus efectos. Esa comparación de los costos es de suma importancia para el análisis de las opciones sobre políticas que se abordan en el epígrafe "Opciones en materia de políticas para hacer frente a la volatilidad y los altos precios", página 35 y siguientes. 


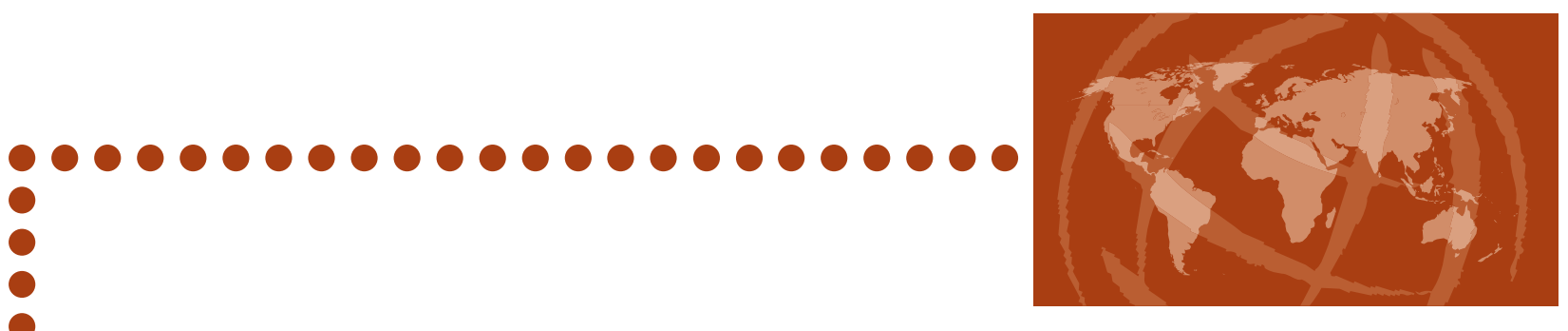

\section{Enseñanzas de la crisis alimentaria mundial de 2006-08}

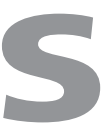
e ha debatido ampliamente sobre qué fue lo que ocurrió en los mercados mundiales de alimentos entre 2006 y 2008 (y más recientemente, en 2010 y 2011), así como sobre las causas subyacentes. La publicación Perspectivas Agrícolas OCDE-FAO contiene un examen de esos acontecimientos ${ }^{40}$. Sin embargo, una cuestión esencial es en qué medida las fluctuaciones de los precios mundiales se transmiten a los precios internos, ya que ni los agricultores ni los consumidores interactúan directamente con los mercados mundiales. En otras palabras, los efectos del nivel y la volatilidad de los precios mundiales sobre la pobreza y la seguridad alimentaria se regulan a través del mecanismo de transmisión de los precios. Esta sección del informe se centra en la evolución de los precios en los mercados nacionales durante la crisis alimentaria mundial de 2006-08.

\section{¿Qué cambios se han registrado en los precios internos de los alimentos básicos desde 2006?}

\section{Mensaje principal}

Los precios internos de los alimentos aumentaron considerablemente en la mayoría de los países durante la crisis alimentaria mundial, con la excepción de algunos grandes países que lograron aislarse de los mercados mundiales. Pero el aislamiento comercial incrementó los precios y la volatilidad en los mercados internacionales, haciendo aumentar los precios internos en países dependientes de las importaciones más de lo que hubieran crecido de otro modo.

El mundo registró un incremento notable de los precios del arroz, el trigo y el maíz en los mercados internacionales durante la crisis alimentaria de 2006-08. En la mayoría de los casos, el incremento repentino de los precios en los mercados internacionales redundó en una subida considerable de los precios internos, aunque estos no aumentaron en algunos países (véase el epígrafe "¿Qué efectos ha tenido la política comercial sobre la transmisión de los precios?"). En julio de 2008, el precio interno del arroz, el trigo y el maíz fue en promedio, para cada uno de estos cultivos y en todos los países, un $40 \%$ aproximadamente más alto que el de enero de 2007 una vez aplicado a este último el ajuste correspondiente a la inflación (Figura 5). Otros estudios han llegado también a la conclusión de que los precios de los mercados mundiales repercutieron notablemente en los precios de los mercados nacionales durante la crisis ${ }^{41}$. Mientras que esta repercusión es con frecuencia limitada en períodos de normalidad, durante la crisis alimentaria mundial resultó considerable ${ }^{42}$.

Si se consideran los promedios anuales, en 2008 los precios internos del arroz, el trigo y el maíz (ajustados en función de la inflación) en la misma muestra de países que se utiliza en la Figura 5 fueron, en promedio, un $28 \%$, un $26 \%$ y un $26 \%$ más elevados, respectivamente, que en 2007 . Pese a ser considerablemente menor que la variación registrada en

\section{FIGURA 5}

Los precios internos del arroz, el trigo y el maíz aumentaron notablemente durante la crisis

\section{Índice (enero de $2007=100$ )}

160

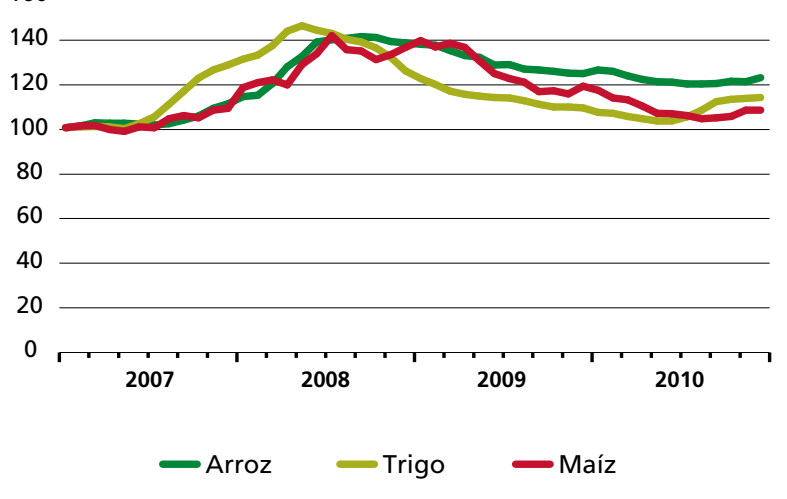

Nota: La figura muestra las tendencias de los precios internos como promedio ajustados en función de la inflación del arroz, el trigo y el maíz de todos los países en el período de enero de 2007 a diciembre de 2010. El precio interno se ha fijado en 100 en enero de 2007 para los distintos países, y el índice de los meses siquientes es iqual al valor medio del índice de los países en su conjunto. Los índices de los precios internos del arroz, el trigo y el maíz se refieren a 42,27 y 34 países, respectivamente, e incluyen todos países respecto a los cuales se disponía de datos en el momento de redactar el presente informe.

Fuente de los datos primarios: Sistema mundial de información y alerta sobre la alimentación y la agricultura (SMIA) de la FAO. 
los mercados mundiales, este incremento habría tenido notables repercusiones en el poder adquisitivo de la población pobre. En países como Bangladesh, Malawi y Viet Nam los pobres suelen gastar un $35 \%$ de sus ingresos, o un porcentaje superior, en alimentos básicos; habida cuenta de que el quintil inferior destina a alimentos el $70 \%$, aproximadamente, de su gasto total (véase la Figura 4, en la página 15), los alimentos básicos representan alrededor de la mitad de los gastos totales en alimentos para el $20 \%$ más pobre de la población. Por consiguiente, en 2008 , los consumidores pobres que no produjeron alimentos básicos registraron una disminución de sus ingresos reales de aproximadamente el $9 \%$ (equivalente al $35 \%$ del presupuesto multiplicado por el aumento de los precios de alrededor del $26 \%$ ). No resulta sorprendente, por tanto, que aumentara también durante la crisis la volatilidad media de los precios internos, la cual alcanzó su nivel máximo en 2008 respecto a los tres cereales (Figura 6).

Después del hundimiento de los precios internacionales de los cereales en el segundo semestre de 2008 , los precios internos finalmente comenzaron a disminuir en la mayoría de los países. En el segundo trimestre de 2010, los precios internos (ajustados en función de la inflación) habían vuelto en gran medida a los niveles de enero de 2007 en lo tocante al trigo y el maíz. Sin embargo los precios internos del arroz se mantuvieron en un nivel relativamente más elevado, al ser en promedio un $20 \%$ más altos respecto a enero de 2007. La tendencia de la variación de los precios internos de todos los cereales fue similar a la de los mercados mundiales, puesto que el mayor incremento de los precios mundiales del arroz se produjo en el período comprendido entre enero de 2007 y el segundo trimestre de 2010.

\section{FIGURA 6}

La volatilidad de los precios internos del arroz,

el trigo y el maíz alcanzó su cota máxima en 2008

Volatilidad de los precios internos como promedio (porcentaje)

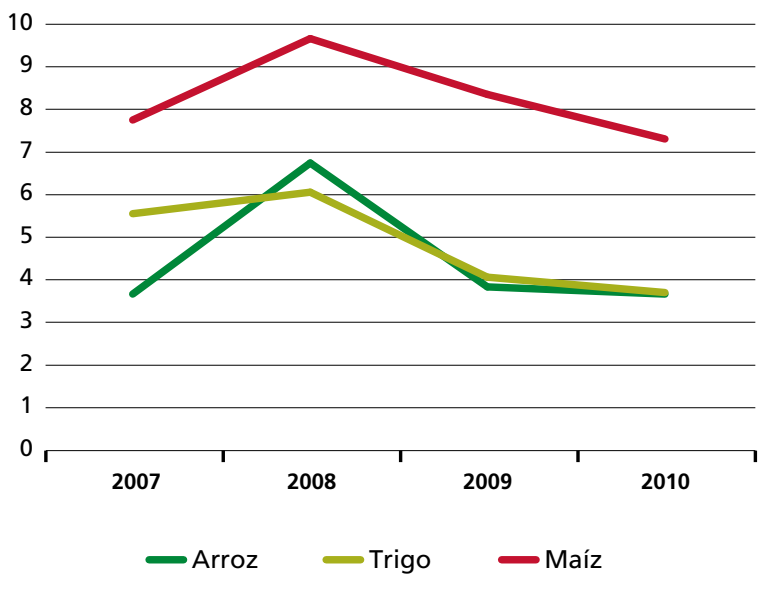

Nota: La volatilidad de los precios internos se calcula como la desviación estándar del logaritmo $\left(P_{t}, P_{t-1}\right)$, utilizando datos mensuales. Los países incluidos son los mismos de la Figura 5. Fuente de los datos primarios: Sistema mundial de información y alerta sobre la alimentación y la agricultura (SMIA) de la FAO.
En el segundo semestre de 2010 y el primeros de 2011, no obstante, los precios mundiales del trigo y el maíz se duplicaron debido a los daños sufridos por la cosecha de trigo en la Federación de Rusia y la prohibición posterior de las exportaciones del cereal en dicho país, así como a las malas condiciones de cultivo del maíz en los Estados Unidos de América y el debilitamiento del dólar estadounidense. Cabe destacar que los precios mundiales del arroz fueron mucho más estables durante ese período. La repercusión de estas conmociones en los mercados nacionales varía de un país a otro, aunque es demasiado pronto para extraer conclusiones generales al respecto. En la siguiente sección del informe se describen las condiciones en que las crisis de los precios mundiales repercuten en la economía nacional así como la forma en que el comercio puede mitigar los efectos de las perturbaciones del suministro interno sobre la volatilidad de los precios.

\section{¿Qué efectos ha tenido la política comercial sobre la transmisión de los precios?}

\section{Mensaje principal}

Las políticas comerciales restrictivas pueden proteger los precios internos de la volatilidad del mercado mundial, pero también pueden redundar en un aumento de la variabilidad como resultado de las perturbaciones del suministro interno. En muchos casos, las políticas gubernamentales imprevisibles son una causa más importante de volatilidad de los precios internos que las fluctuaciones de precios del mercado mundial.

La repercusión de los precios de los mercados mundiales en los mercados nacionales depende de varios factores, que incluyen los costos de transporte, el grado de autosuficiencia de los países, los tipos de cambio y las crisis internas. La política comercial, sin embargo, es quizá el principal factor determinante de la medida en que las alteraciones de los precios mundiales se reflejan en los mercados internos. Las intervenciones de política comercial fueron relativamente frecuentes en los países en desarrollo durante la crisis alimentaria mundial; por lo menos 55 países las utilizaron como instrumento para mitigar los efectos de la crisis alimentaria mundial de 2006-0843.

En particular, el factor fundamental que influye en la transmisión de los precios es la medida en que el gobierno determina el volumen de comercio (tanto de las exportaciones como de las importaciones), en lugar de permitir al sector privado que tome decisiones al respecto. El control del gobierno puede ejercerse de manera formal mediante la aplicación de cupos fijos o bien de forma más flexible a través de la determinación de cupos que varían en función de los acontecimientos externos. Los cupos aplicados 
a la exportación pueden mitigar la repercusión de los altos precios mundiales en la economía nacional, mientras que los fijados para la importación están en condiciones de evitar la transmisión de precios mundiales muy bajos.

Por ejemplo, durante la crisis alimentaria mundial de 2006-08, los precios internos del arroz y el trigo fueron muy estables en China, la India e Indonesia debido a los controles gubernamentales sobre las exportaciones de estos cultivos (véase la Figura 7 para China) ${ }^{44}$. Estos controles se ejercen incluso en períodos de normalidad y no se aplicaron específicamente en respuesta a la crisis. Es importante señalar que, si bien los controles del comercio en China evitaron de hecho la repercusión de los precios de los mercados mundiales, este país ha mantenido una política comercial generalmente abierta en el sentido de que los precios internos del arroz son, en la mayoría de los casos, similares a aquellos de los mercados mundiales - el gobierno no adopta medidas coactivas de forma sistemática a fin de que los precios internos del arroz se sitúen por encima o por debajo de los precios mundiales-. Además, los precios internos de la soja en China aumentaron de forma brusca en 2007 y 2008, debido a que el gobierno no controla el comercio de ese producto básico (Figura 8). China importa además una gran proporción de la soja que consume, por lo que no sería pertinente aplicar restricciones a la exportación.

Por supuesto, no siempre los controles gubernamentales del comercio conducen a precios más estables y previsibles (Recuadro 6). Malawi, por ejemplo, concertó exportaciones de maíz en 2007/08 y 2008/09, pero los suministros internos no fueron suficientes para apoyar las exportaciones y los precios internos subieron de forma repentina. En 2005, Zambia no

\section{FIGURA 7}

El control gubernamental del comercio de arroz evitó que los altos precios del mercado mundial repercutieran en los precios internos en China durante la crisis alimentaria de 2006-08

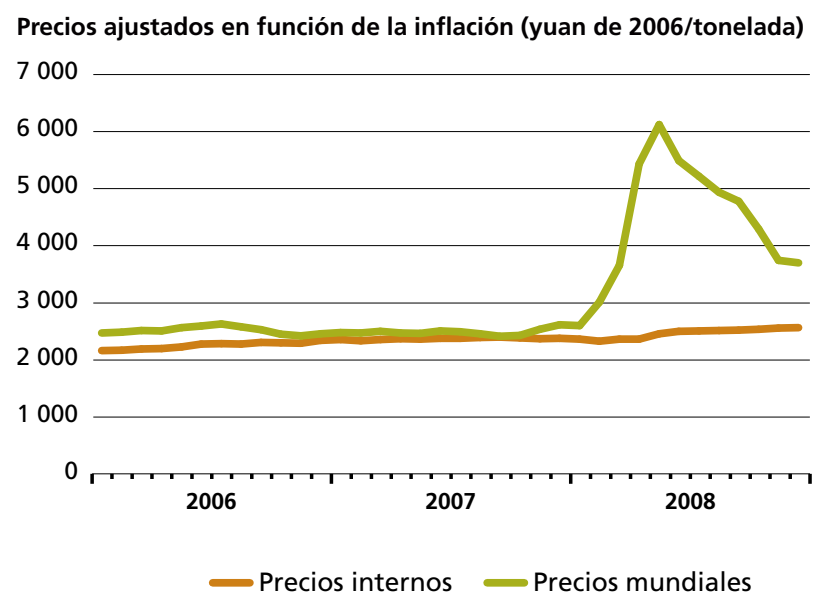

Fuente: C. Fang. 2010. How China stabilized grain prices during global price crisis: En D. Dawe (editor). The rice crisis: markets, policies and food security. Londres, Earthscan y Roma, FAO. previó correctamente el suministro interno de maíz y tardó en expedir licencias de importación. Una vez que se emitieron, se produjo confusión sobre el nivel del arancel de importación que habría de aplicarse, al haber opiniones discordantes sobre el tema entre los poderes públicos. Después de que se aclarara la cuestión del arancel se introdujeron nuevos reglamentos sanitarios y fitosanitarios, lo cual volvió a generar incertidumbre entre los comerciantes del sector privado. La consiguiente demora hizo difícil la contratación de servicios de transporte a un costo razonable porque la mayoría de los camiones disponibles en la región ya habían sido reservados para otros fines. Por último, la licitación de importaciones no se concluyó hasta varios meses después de que el gobierno hubiera anunciado la cantidad de maíz que importaría. Ello generó incertidumbre respecto al momento en que llegarían las importaciones públicas al mercado ${ }^{45}$. Todos estos factores crearon un entorno de gran incertidumbre para los importadores del sector privado que, como resultado, importaron mucho menos de lo que hubieran podido importar en otras circunstancias. El resultado neto fue un marcado repunte de los precios en los mercados nacionales a finales de 2005 y comienzos de 2006 (un aumento del $68 \%$ en nueve meses), a pesar de que los precios internacionales se mantuvieron estables (Figura 9). Dicho aumento podría haber sido aún peor si no se hubiera registrado una apreciación del kwacha de Zambia en ese momento. Hay muchos ejemplos similares ${ }^{46}$.

Aún cuando los controles sobre el volumen de comercio sirven para estabilizar los precios internos, esas políticas tienen sus costos. En cuanto a las pérdidas para la economía nacional, a corto plazo se reduce la eficiencia de la economía al no permitir que los precios internos fluctúen con los mundiales. A

\section{FIGURA 8}

El Gobierno de China no controla el comercio de soja, por lo que los precios internos siguen los precios del mercado mundial

Precios ajustados en función de la inflación (yuan de 2006/tonelada)

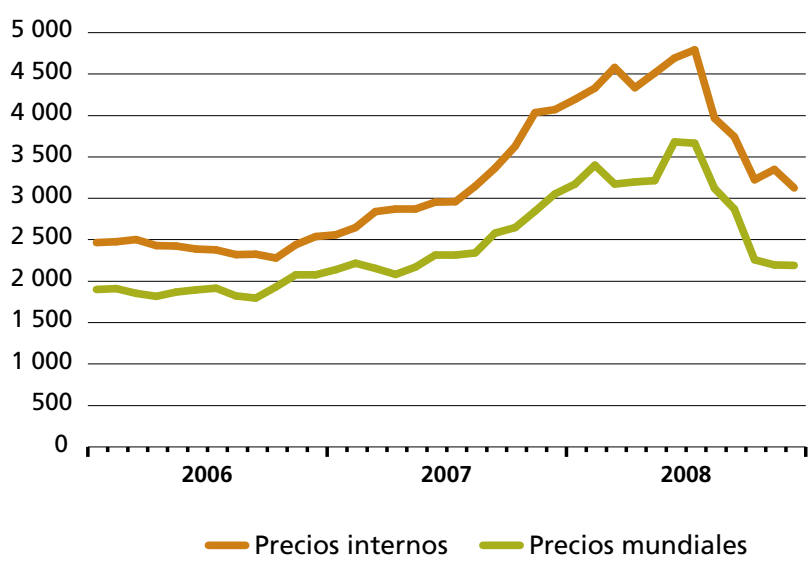

Fuente: C. Fang. 2010. How China stabilized grain prices during global price crisis: En D. Dawe (editor). The rice crisis: markets, policies and food security. Londres, Earthscan y Roma, FAO. 


\section{FIGURA 9}

La incertidumbre del mercado causada por las

intervenciones del Gobierno en el mercado interno

de maíz hizo que el precio del maíz en Zambia aumentara

bruscamente en 2005-06, a pesar de que los precios

del mercado internacional se mantuvieron estables

\section{Precios ajustados en función de la inflación} (kwacha de Zambia de 2005/kg)

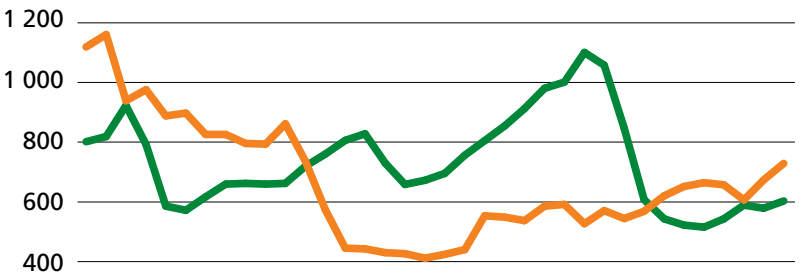

200

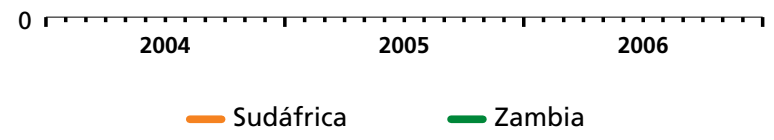

Nota: Los precios del maíz blanco de Sudáfrica son representativos del precio mundial ya que Sudáfrica es la fuente principal de maíz blanco de la región.

Fuente de los datos primarios: Sistema mundial de información y alerta sobre la alimentación y la agricultura (SMIA) de la FAO.

corto plazo, la respuesta de la oferta se enfrenta a obstáculos y hay pérdidas de ingresos por exportaciones (sin embargo, si los agricultores están también protegidos de la caída de los precios, los controles del comercio podrían aumentar la respuesta de la oferta en otros momentos). Además de las pérdidas que supone para la economía nacional, las restricciones a la exportación redundan también en un incremento del nivel y la volatilidad de los precios mundiales mayor que el que se habría registrado si no se hubieran adoptado esas medidas, con el consiguiente costo para otros países.

El otro instrumento principal de la política comercial, que son los aranceles sobre la importación o los derechos de exportación, en muchos casos no evitará la repercusión de las alteraciones de los precios mundiales en los mercados nacionales a menos que esos aranceles o derechos varíen en función de las fluctuaciones de los precios mundiales. Los aranceles de importación constantes aumentarán el precio interno de los alimentos (y los derechos de exportación lo reducirán), pero si el sector privado puede elegir las cantidades que importará con un arancel determinado lo más probable es que los cambios en los precios mundiales se repercutan totalmente en los precios internos hasta que los precios mundiales, o el arancel, sean tan elevados como para que no se realicen más importaciones.

Si bien los controles del comercio pueden evitar la repercusión de los precios volátiles de los mercados internacionales, esas políticas tienen también inconvenientes. Por ejemplo, los controles pueden aumentar la volatilidad de los precios debido a las perturbaciones del suministro interno (véase el epígrafe "¿Qué consecuencias tiene la autosuficiencia para la volatilidad de los precios?"). El incremento de los precios internos, en la mayoría de los casos, suele asimismo agravar la pobreza (véase el apartado "Costos y beneficios de los precios altos y bajos de los alimentos").

\section{¿Qué efectos han tenido los tipos de cambio sobre los precios mundiales y su transmisión?}

Las fluctuaciones de los tipos de cambio tienen dos efectos distintos importantes. En primer lugar, se reflejan en los precios mundiales expresados en dólares estadounidenses (USD). Por ejemplo, una depreciación del USD frente a otras divisas significa que el precio mundial de un producto básico expresado en USD se reduce frente a esas otras divisas. El precio más bajo en divisas distintas del USD aumenta la demanda y reduce la oferta de esos países; ambos efectos contribuyen a un incremento del precio expresado en USD.

En segundo lugar, las fluctuaciones de los tipos de cambio pueden compensar las variaciones de los precios expresados en USD en los mercados mundiales, ayudando a reducir la transmisión de las fluctuaciones de los precios a los mercados internos. Ello no evitó la repercusión de las perturbaciones de los precios mundiales sobre los precios internos durante la crisis alimentaria de 2006-08, por el simple hecho de que la crisis de los precios mundiales fue de gran envergadura. Sin embargo, no deben ignorarse los efectos de las fluctuaciones de los tipos de cambio. Por ejemplo, en el período comprendido entre enero de 2003 y diciembre de 2010 el precio mundial del arroz aumentó un $169 \%$ en valores nominales expresados en USD, pero únicamente un $116 \%$ en valores nominales expresados en francos CFA (Comunidad Financiera Africana). La diferencia se debió a la apreciación del euro (moneda a la que está vinculado el franco CFA) frente al $\mathrm{USD}^{47}$. Por tanto, incluso a falta de políticas nacionales en materia de productos básicos, el incremento de los precios mundiales repercutió en menor medida en el África occidental de lo que cabía esperar habida cuenta de las tendencias de los precios mundiales en USD (Figura 10). En determinadas circunstancias, la influencia de los tipos de cambio puede ser fundamental: de enero de 2006 a noviembre de 2007, un período de casi dos años, los precios mundiales del arroz aumentaron un $25 \%$ en valores nominales en USD, pero únicamente un $3 \%$ en valores nominales en francos CFA.

\section{¿Qué consecuencias tiene la autosuficiencia para la volatilidad de los precios?}

\section{Mensaje principal}

Una estrategia en materia de seguridad alimentaria que se base en una combinación de mayor productividad y apertura general al comercio será más eficaz que una estrategia basada principalmente en el cierre de fronteras. 


\section{¿Las restricciones a la exportación reducen o estabilizan los precios internos?}

En muchos casos las restricciones y los impuestos sobre la exportación parecen estabilizar, de hecho, los precios internos. Esto puede ocurrir sobre todo cuando las restricciones han estado en vigor durante un período de tiempo lo suficientemente prolongado como para que se hayan establecido los mecanismos de aplicación pertinentes. La Argentina, por ejemplo, ha aplicado impuestos a la exportación de trigo durante muchos años y no registró los mismos bruscos aumentos de los precios internos que se observaron en los mercados mundiales en 2007 y 2010 (véase la figura). Sin embargo, un impuesto sobre la exportación no estabilizaría los precios si no aumentara cuando se incrementan los precios mundiales, o no fuera tan elevado

Los controles de las exportaciones protegieron los precios internos del trigo en la Argentina de las bruscas subidas registradas en el mercado mundial en 2007 y 2010

\section{Precios ajustados en función de la inflación} (pesos argentinos de 2005/tonelada)
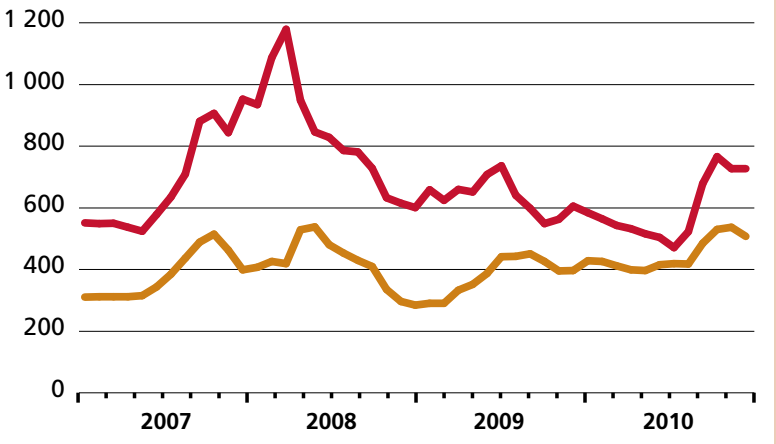
Mundo - Argentina

\footnotetext{
Notas: Precios mundiales del trigo duro rojo de invierno estadounidense de proteína normal y franco a bordo (FOB) del Golfo de los Estados Unidos de América. Precios internos del trigo duro al por mayor de Córdoba.

Fuentes de los datos primarios: Sistema mundial de información y alerta sobre la alimentación y la agricultura (SMIA) de la FAO, Consejo Internacional de Cereales (CIC), Fondo Monetario Internacional (FMI).
}

como para eliminar todas las exportaciones. Así, además de los impuestos sobre la exportación, en la Argentina se utilizaron controles cuantitativos del comercio de trigo durante 2007' lo cual redujo la magnitud del alza en los mercados internos.

Como muestra la figura, sin embargo, la mayor estabilidad se logró a cambio de unos precios constantemente bajos para los agricultores, lo cual redujo los incentivos para la producción. Además, si bien los precios al productor se estabilizaron, los controles fueron mucho menos eficaces en cuanto a estabilizar los precios al consumidor. El trigo representa solo el $10 \%$, aproximadamente, del costo del pan, lo cual significa que incluso si este cereal se diera gratuitamente a los molineros y panaderos el costo de producción del pan se reduciría tan solo en un $10 \% 2$.

Sin embargo, no todos los países que imponen controles sobre las exportaciones son capaces de estabilizar los precios internos satisfactoriamente. Viet Nam, por ejemplo, impuso restricciones a las exportaciones de arroz en los primeros meses de 2008. A pesar de que los suministros internos eran más que suficientes para alimentar a la población, los precios internos al por menor aumentaron un $50 \%$ en solo cinco semanas entre abril y mayo de 2008. Las políticas gubernamentales, tales como los impuestos de exportación, también cambiaron frecuentemente, generando más incertidumbre y riesgos para los comerciantes a finales de año cuando los precios en los mercados mundiales habían disminuido. De hecho, los precios internos aumentaron un $20 \%$ en solo dos semanas en la segunda quincena de agosto de 2008 pese a las escasas fluctuaciones registradas en los mercados mundiales en ese período ${ }^{3}$.

$1 \mathrm{~J}$. Nogues. 2011. Agricultural export barriers and domestic prices: Argentina during the last decade. Informe preparado por la FAO. 2 Ibídem.

3 P. Hoang Ngan. 2010. The Vietnamese rice industry during the global food crisis. En D. Dawe. (editor). The rice crisis: markets, policies and food security. Londres, Earthscan y Roma, FAO.
A primera vista, podría parecer obvio que un país que depende notablemente de las importaciones tenga más probabilidades que un país autosuficiente o exportador de sufrir un incremento considerable de los precios internos ante una tendencia alcista de los precios mundiales. En ausencia de costos de transporte o intervenciones gubernamentales, sin embargo, un incremento de los precios mundiales se reflejará directamente en los precios internos tanto de un país importador como de uno exportador o autosuficiente. Ello se debe a que los comerciantes del sector privado tendrían libertad para trasladar los suministros de los mercados internos a los mercados mundiales y viceversa, hasta que los precios fueran iguales en todos los mercados. De hecho, incluso los países exportadores registran un incremento de los precios internos cuando aumentan los del mercado mundial. Por ejemplo, los precios internos del arroz en Tailandia aumentaron considerablemente en 2008 ya que este país no impone restricciones cuantitativas a las exportaciones de arroz del sector privado ${ }^{48}$.

Así, el ser casi autosuficiente puede reducir la vulnerabilidad a las crisis de los precios mundiales, pero solo porque ello brinda a los países la posibilidad de 


\section{FIGURA 10}

La apreciación del franco CFA frente al dólar

estadounidense en el período de 2003 a 2010 supuso que el aumento de los precios mundiales del arroz fuera

menor en francos CFA que en dólares estadounidenses

Índice de precios nominales $(2003=100)$

600
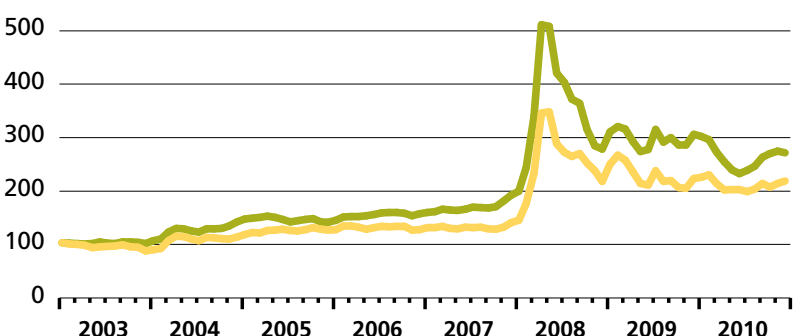

USD Francos CFA

Nota: Los precios nominales se utilizan en lugar de los precios reales con el fin de aislar la repercusión de las fluctuaciones del tipo de cambio de los efectos de la deflación con dos indices de precios diferentes.

Fuentes de los datos primarios: FAO, Fondo Monetario Internacional (FMI).

imponer controles sobre el comercio internacional sin verse afectados por un incremento considerable de los precios internos. Cuanto más autosuficiente es un país, menor es la repercusión de los precios del mercado mundial en los precios internos ya que en esas condiciones es probable que, ante un aumento de los precios mundiales, las importaciones del sector privado no resulten rentables. Ello supone que las exportaciones no se permitirán o no serán rentables (por ejemplo, debido a problemas de calidad); si se permiten o son rentables, los precios mundiales repercutirán en los precios internos. Para un país que depende en gran medida de las importaciones, sin embargo, es más probable que los precios internos aumenten debido a que la dependencia elevada de las importaciones muy posiblemente refleje un elevado costo de producción nacional.

Por otro lado, es importante tomar en consideración que la volatilidad de los precios puede deberse a perturbaciones internacionales o nacionales ${ }^{49}$. Cuando un país es autosuficiente (porque las importaciones no son rentables debido a los obstáculos al comercio, los aranceles o los costos elevados de transporte), el comercio no puede aplacar las perturbaciones del suministro interno. Ello puede exacerbar la volatilidad de los precios causada por las fluctuaciones de la producción agrícola debido a las irregularidades meteorológicas. En tales casos, las existencias reguladoras nacionales pueden funcionar como un sustituto del comercio internacional: ponerse en circulación cuando la producción nacional es baja y acumularse cuando hay una buena cosecha.

Algunos países han utilizado las existencias reguladoras de forma eficaz para estabilizar los precios internos, pero no es el caso de muchos otros. Además, los costos de mantenimiento de esas existencias pueden ser elevados. Por ejemplo, en Bangladesh, en la mayoría de los casos sería más económico utilizar importaciones para reducir la volatilidad de los precios que almacenar arroz ${ }^{50}$. El dinero invertido en el mantenimiento de las existencias tiene un costo de oportunidad en cuanto a inversiones fundamentales en investigación agrícola, caminos rurales y otros bienes públicos que son esenciales para la solidez del sector agrícola y para el crecimiento económico a largo plazo (véase el apartado "Costos y beneficios de los precios volátiles e imprevisibles"). De hecho, numerosos gobiernos toman en consideración los gastos que comporta el mantenimiento de dichas existencias y suelen reducirlas cuando los precios se mantienen relativamente estables durante varios años. Por consiguiente, el comercio debería seguir siendo un elemento esencial de una estrategia de seguridad alimentaria racional.

También es importante distinguir entre la autosuficiencia lograda a través de restricciones al comercio y aquella obtenida por un sector agropecuario competitivo. Las restricciones a la importación pueden permitir a un país alcanzar la autosuficiencia, pero es mucho más difícil avanzar hacia la autosuficiencia a través de la inversión productiva que hace que el sector agrícola sea competitivo en los mercados mundiales. Sin embargo esta competitividad debe ser el objetivo real, porque es la única manera de que el sector reporte beneficios a largo plazo tanto para los agricultores como para los consumidores.

Bangladesh es un ejemplo de país que ha realizado notables progresos en la reducción de la subnutrición manteniendo al mismo tiempo la apertura general al comercio y aumentando la productividad. El gobierno permite a los comerciantes del sector privado importar arroz a un arancel generalmente bajo, por lo que en los últimos 20 años los precios internos del arroz han sido más o menos similares a los de los países vecinos, entre ellos los grandes exportadores como la India y Tailandia. Al mismo tiempo, el rendimiento del arroz ha crecido rápidamente en los últimos 20 años gracias a la inversión en semillas mejoradas y en infraestructuras de riego. Los precios internos del arroz aumentaron en el período de 2007-08, pero los precios cayeron de forma brusca a partir de mediados de 2008 debido a un rápido aumento de la producción nacional.

La experiencia de la República Dominicana ofrece un ejemplo diferente. El gobierno recurre a cupos, precios mínimos de apoyo y otras medidas para influir en los precios internos del arroz y aumentar la autosuficiencia. Los precios internos aumentaron solo un $11 \%$ de 2007 a 2008 (en valores nominales expresados en USD) mientras que en los países vecinos subieron entre un $26 \%$ (Costa Rica) y un $59 \%$ (El Salvador). Sin embargo, este menor porcentaje de 
incremento de los precios tuvo un costo que se traduce en precios más altos en períodos de mayor normalidad antes y después de la crisis; los cupos comportan una restricción a la importación, lo cual incrementa los precios internos. Incluso durante la crisis, los precios del arroz en la República Dominicana estaban a niveles similares a aquellos de los países vecinos (Figura 11). Por tanto, las políticas de restricción de las importaciones han redundado en una mayor estabilidad, pero a expensas de precios más altos en casi todos los momentos. Además, como se explica en el epígrafe "Costos y beneficios de los precios altos y bajos de los alimentos", el encarecimiento de los alimentos básicos agrava la pobreza en la mayoría de los países.

Asimismo, si los precios de los alimentos básicos de un determinado país son más altos que aquellos de los países vecinos este puede perder competitividad en sectores que utilizan mucha mano de obra, ya que se verá obligado a aumentar los salarios para compensar el encarecimiento de los alimentos. Esto podría reducir las oportunidades de empleo, cerrando un camino para salir de la pobreza a través del sector no agrícola. Por tanto, la autosuficiencia lograda mediante restricciones al comercio y no mediante el aumento de la productividad tiene muchos efectos secundarios negativos. En resumen, una estrategia de seguridad alimentaria que se base en una combinación de mayor productividad y apertura al comercio en general será más eficaz para mejorar la seguridad alimentaria y reducir la pobreza que una estrategia basada principalmente en el cierre de fronteras.

\section{FIGURA 11}

Las medidas adoptadas por el Gobierno de la República Dominicana redujeron los efectos del alza de los precios del arroz en 2008 , pero a expensas de la subida de los precios antes y después de la crisis

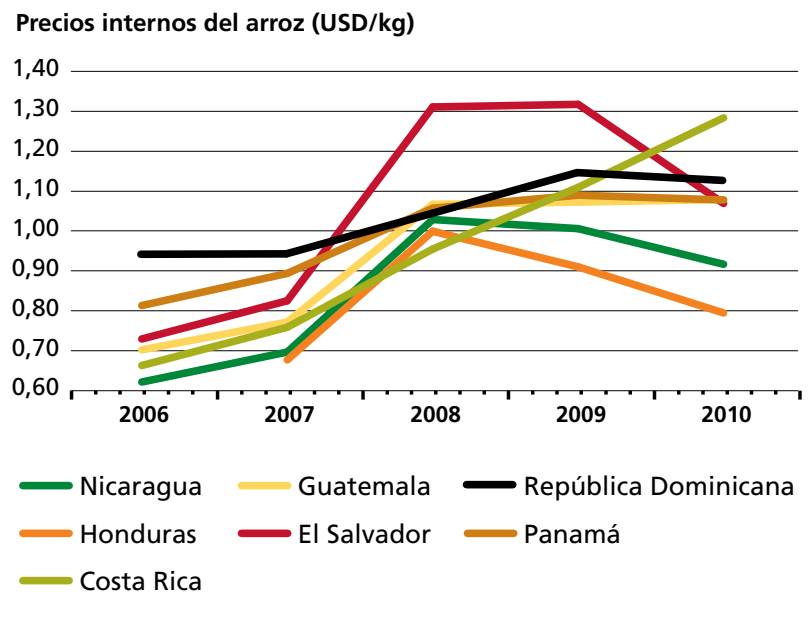

Fuente de los datos primarios: Sistema mundial de información y alerta sobre la alimentación y la agricultura (SMIA) de la FAO.

\section{¿Están protegidos los alimentos básicos tradicionales de las fluctuaciones de los precios mundiales?}

\section{Mensaje principal}

A pesar de las perturbaciones de los precios en los mercados mundiales, la volatilidad de los precios internos de alimentos básicos tradicionales como el sorgo, el mijo y la yuca es mayor que la de los principales cereales comercializados (el arroz, el trigo y el maíz).

Algunos observadores han señalado que los consumidores de países como Ghana y Uganda, que utilizan una mayor variedad de alimentos básicos, son menos vulnerables al incremento repentino de los precios en los mercados internacionales que aquellos que dependen de los cereales principales. Así, algunos analistas han sugerido que las poblaciones pobres que sufren inseguridad alimentaria deberían utilizar más alimentos básicos amiláceos tradicionales (como la yuca, el mijo y el sorgo), cuyos mercados internacionales son mucho más pequeños y están menos integrados en los mercados nacionales, en detrimento de los cereales principales. ¿Qué conclusiones se pueden extraer a este respecto de las fluctuaciones de los precios internos durante la crisis alimentaria mundial?

En primer lugar, durante dicha crisis los precios de los alimentos básicos tradicionales acusaron generalmente un alza, es decir, no se mantuvieron al margen de los acontecimientos. Esto es exactamente lo que cabía esperar si los consumidores acrecentaban su demanda de alimentos básicos tradicionales en respuesta al aumento de los precios de los cereales principales y los productores incrementaban la oferta de los cereales principales a expensas de los alimentos básicos tradicionales. Sin embargo, aun cuando los precios de los alimentos básicos tradicionales aumentaron su incremento fue casi siempre menor que el de los precios de los cereales principales, en consonancia con lo que prevé la teoría económica. En una muestra de 32 pares de productos básicos (formados por un cereal principal y un alimento básico tradicional del mismo país de África), entre 2006 y 2008 los precios de los cereales principales aumentaron en promedio un $21 \%$ más que los de los alimentos básicos tradicionales. Además, esta tendencia se mantuvo en cada uno de los 11 países analizados por separado. Así, la tendencia los precios de los cereales principales a sufrir un incremento mayor que los de los alimentos básicos tradicionales se reveló bastante fuerte en África.

No obstante, como se ha señalado anteriormente, una menor dependencia de los mercados internacionales no comporta necesariamente una mayor estabilidad de los precios. De hecho, la comparación de la volatilidad de los 
precios internos de todos los productos básicos de 20 países de África ${ }^{51}$ lleva a una conclusión sorprendente: dicha volatilidad fue menor para el arroz o el trigo en los 20 países entre 2005 y 2010, a pesar de que en ese período se observó una enorme inestabilidad en los mercados mundiales de ambos cereales (Figura 12). Al parecer, si bien durante ese período se registró un repunte notable de los precios del arroz y el trigo seguido de una caída, en el mismo lapso fueron varios los repuntes y las caídas de los precios internos de los alimentos básicos tradicionales. Ello se debe probablemente a que las perturbaciones del suministro interno son un factor decisivo de la volatilidad de los precios, especialmente en África, donde una gran proporción de la producción es de secano y no de regadío. De hecho, a nivel mundial, el 62 $\%$, el $31 \%$ y el $20 \%$ de la superficie cultivada de arroz, trigo y maíz, respectivamente, corresponde a tierras de regadío frente al $9 \%$, el $5 \%$ y el 0,1\% de la superficie cultivada con sorgo, mijo y yuca ${ }^{52}$. Además, gran parte de la producción de alimentos básicos tradicionales se destina al consumo doméstico, lo cual significa que los mercados de estos productos son pequeños y residuales y, por tanto, están sujetos a mayores fluctuaciones de los precios. Por último, la falta de información sobre los mercados (en comparación con la que se encuentra disponible en el caso de los principales cereales comercializados) puede suponer que la producción de estos alimentos tradicionales esté más sujeta a comportamientos cíclicos en los que un precio elevado alienta una producción excesiva, que lleva luego a precios bajos y a una producción insuficiente, y así sucesivamente.

La volatilidad de los precios del maíz con frecuencia fue menor que la de los alimentos básicos tradicionales, aunque no haya sido así en todos los casos. Ello se debe probablemente a que los precios internos del maíz no tienen vínculos tan estrechos con los mercados internacionales como los del arroz y el trigo, los cuales se importan en gran medida. Esta menor vinculación se debe a que la mayor parte del maíz que se consume en África es maíz blanco, diferente del amarillo que se comercializa en los mercados mundiales. Ello hace que los precios internos sean más vulnerables a las perturbaciones del suministro interno, como en el caso del sorgo, el mijo y la yuca.

En resumen, si se incrementan los precios internacionales de los cereales, tiene sentido para los consumidores pasar a alimentos básicos tradicionales con el fin de reducir las repercusiones sobre su presupuesto familiar hasta que los precios de los cereales principales vuelvan a niveles más normales. Por lo tanto, consumir una variedad de alimentos básicos ofrece un potencial amortiguador contra las crisis de los precios mundiales. No obstante, al parecer los precios de los alimentos básicos tradicionales son más inestables que los precios de los principales cereales, y no lo contrario.

\section{FIGURA 12}

Los precios internos del trigo, maíz y arroz fueron menos volátiles que los precios de los alimentos básicos tradicionales en África en el período comprendido entre 2005 y 2010

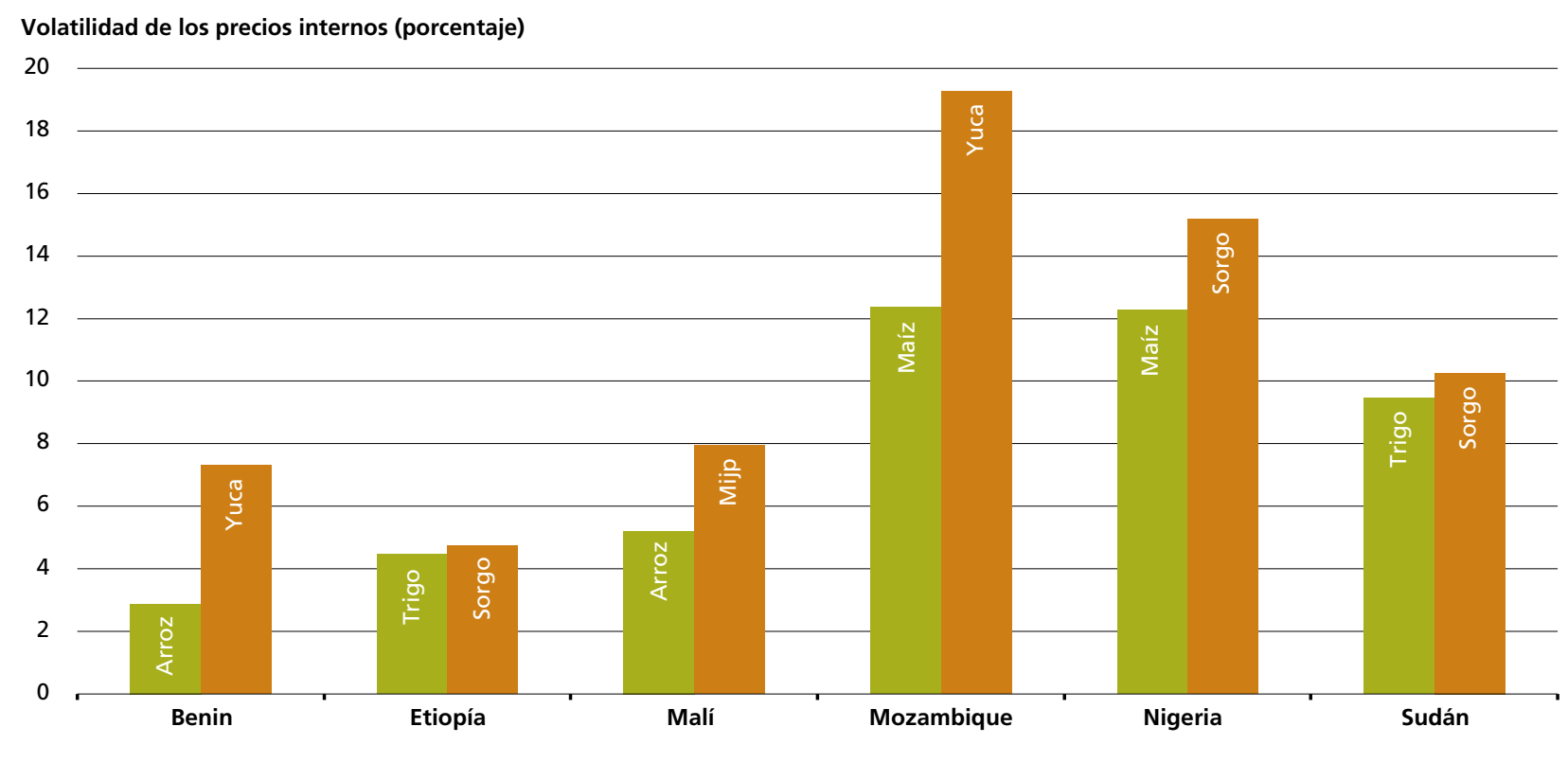

Nota: La volatilidad se ha calculado como la desviación estándar de la variación mensual de los precios ajustados en función de la inflación. Fuente de los datos primarios: Sistema mundial de información y alerta sobre la alimentación y la agricultura (SMIA) de la FAO. 
Por supuesto, el debate sobre las ventajas y los inconvenientes relativos de los cereales importados y los alimentos básicos tradicionales abarca muchas cuestiones y no únicamente la volatilidad de los precios. Por ejemplo, los diferentes cultivos generarán diversos niveles de beneficios. Además, si un hogar agrícola opta por cambiar los cultivos que produce, ello podría afectar a la asignación del trabajo, así como de los ingresos, dentro del hogar, ya que algunos cultivos se consideran trabajo de hombres y otros aptos para las mujeres. Las decisiones sobre el consumo también pueden afectar a la distribución del tiempo; una mayor dependencia de alimentos que requieren más tiempo de elaboración y cocción aumenta el gasto de energía de las mujeres y reduce su tiempo disponible para otras actividades productivas, para el cuidado de los hijos y para el descanso necesario ${ }^{53}$. El contenido nutricional de los diferentes alimentos es también de suma importancia.

¿Cómo respondieron los precios al productor durante la crisis alimentaria mundial?

\section{Mensaje principal}

Los datos parecen indicar que, en los países en que aumentaron los precios al por menor durante la crisis alimentaria mundial, se incrementaron también los precios al productor. Sin embargo, la volatilidad de los precios durante la crisis aumentó los riesgos para los agricultores y no promoverá inversiones a largo plazo por parte de los pequeños productores.

La magnitud de la respuesta de la oferta en los países en desarrollo estará determinada por la repercusión de los precios mundiales no solo para los minoristas, sino también para los productores. Si los precios al productor no aumentan, no habrá respuesta de la oferta.

Aunque se sabe de muchos casos en que los precios al por menor se incrementaron sin que crecieran los precios al productor, es fundamental contar con datos sólidos sobre estos últimos para abordar la cuestión de manera convincente. Si bien esa información no se encuentra tan fácilmente como aquella sobre los precios al consumidor, existen algunos datos que pueden utilizarse. El aumento porcentual de los precios al productor del arroz, el trigo y el maíz fue muy similar al de los precios al consumidor en varios países asiáticos (Bangladesh, China, Indonesia, Filipinas y Tailandia) entre 2003 y $2008^{54}$. En la República Unida de Tanzanía, los precios al productor del maíz mostraron una tendencia similar a la de los precios al consumidor desde 2007 hasta 200855; los datos a más largo plazo de Burkina Faso sobre el maíz blanco y el amarillo muestran también fluctuaciones similares de los precios al productor y al consumidor (Figura 13). En Kenya, los precios al productor del maíz también aumentaron considerablemente durante la crisis alimentaria mundial56. De estos datos (que se resumen en la Figura 14) parece desprenderse que por lo general los precios al productor aumentan cuando se incrementan los precios al consumidor.

Si bien las fluctuaciones generales de los precios al productor y al consumidor a lo largo del tiempo suelen ser similares, los beneficios brutos de la comercialización (diferencia entre los precios al por menor y al productor) no son siempre constantes. Estos beneficios presentan una variación estacional, siendo mayores en el momento más intenso de la cosecha porque los cereales cosechados en ese período han de almacenarse por más tiempo antes de su venta que los cereales que se recogen fuera de temporada. Además, dichos beneficios pueden aumentar en momentos en que los precios son menos previsibles, ya que una menor previsibilidad significa un mayor riesgo para los comerciantes. Esto fue lo que sucedió en 2008 con los beneficios de comercialización del arroz en Tailandia y Filipinas: los precios al productor aumentaron considerablemente, pero no tanto como los precios al por mayor y al por menor.

De hecho, muchos comerciantes perdieron dinero durante la crisis alimentaria mundial ${ }^{57}$. Los precios al productor subieron tan rápido que a menudo los comerciantes obtenían suministros únicamente a un precio superior al precio de venta que habían acordado con sus clientes. Como consecuencia, tuvieron pérdidas, muchas de ellas importantes. También es posible que los comerciantes tuvieran un poder de monopolio que aprovechaban para aumentar los beneficios, aunque sería difícil decir qué parte del incremento se debió a un comportamiento monopolístico y cuál fue la compensación por un mayor riesgo. Por último, los costos de la comercialización aumentaron también durante el período de la crisis alimentaria mundial, debido a los mayores costos de los combustibles.

\section{FIGURA 13}

Los precios al productor para el maíz blanco mostraron una tendencia muy similar a la de los precios al por menor en Burkina Faso en el período de 2003 a 2010

Precios ajustados en función de la inflación (francos CFA de 2008/kg)

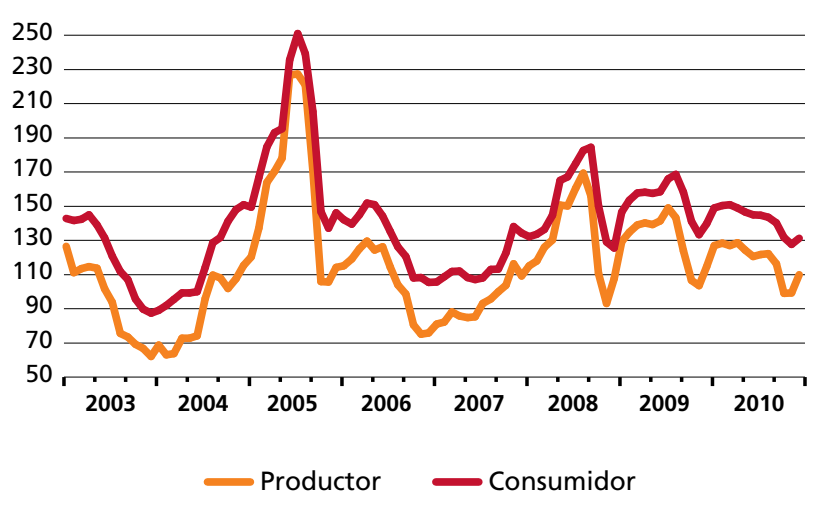

Fuente de los datos primarios: Fondo Monetario Internacional (FMI), Burkina Faso. 


\section{FIGURA 14}

Los precios al productor en general aumentaron al igual que los precios al por menor en el período de 2003 a 2008

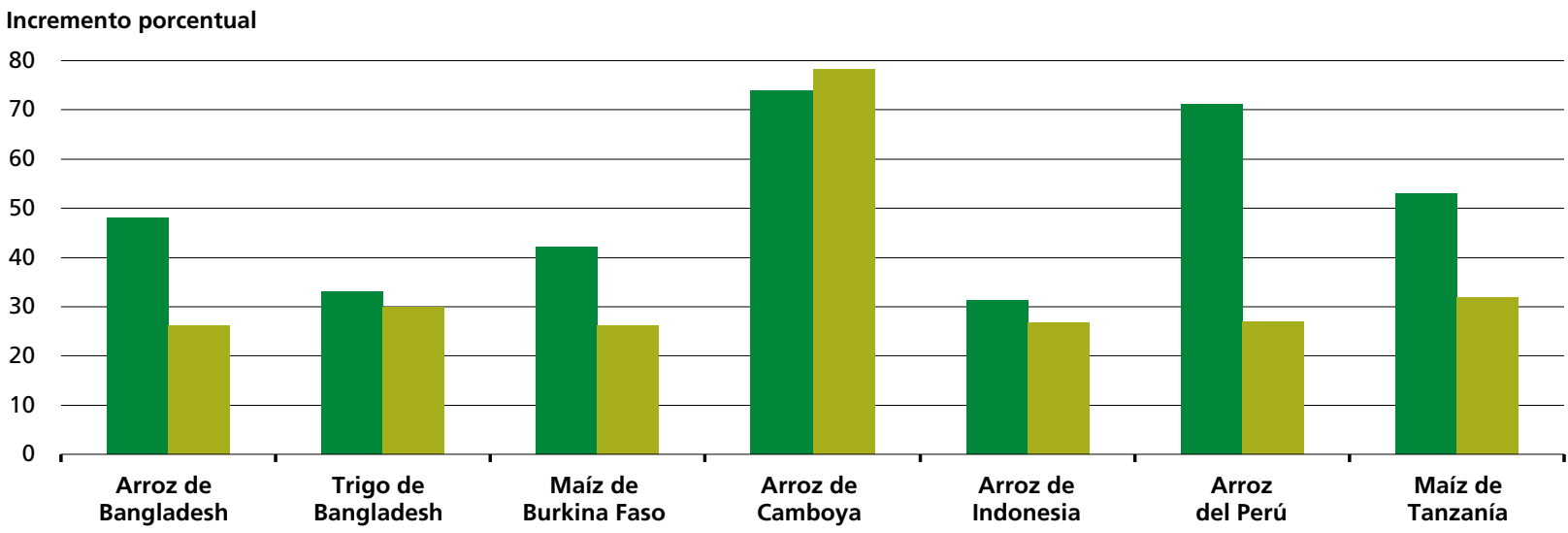

Precios al productor Precios al por menor

Notas: Con arreglo a los precios ajustados en función de la inflación. Variación de los precios del trigo de Bangladesh en el período de 2003 a 2006 y del maíz de Tanzanía en el período de 2007 a 2008

Fuente de los datos primarios: Organismos nacionales de estadística.

\section{El encarecimiento de los fertilizantes ¿neutralizó los incrementos de los precios al productor?}

\section{Mensaje principal}

El incremento de los precios de los fertilizantes perjudicó a los productores, pero en numerosas ocasiones los precios más altos de los cultivos compensaron con creces los costos adicionales. Esto condujo a una respuesta considerable de la oferta de cereales en numerosos países en 2008.

Entre 2001 y 2008, los precios mundiales de los fertilizantes a base de nitrógeno, fósforo y potasio aumentaron más que los precios mundiales de los cereales (Figura 15). El precio de la urea, fuente primordial de nitrógeno y uno de los fertilizantes más utilizados, aumentó más de cuatro veces en valores reales de 2001 a 2008. La rentabilidad de la explotación agrícola se redujo por las repercusiones de la subida de los precios mundiales para los agricultores y, por consiguiente, disminuyó el potencial de respuesta de la oferta. Sin embargo, la compensación de los precios de los fertilizantes por el aumento de los precios al productor posiblemente sea menor de lo que suele creerse.

En los sistemas tradicionales de producción que utilizan pocos fertilizantes, como es a menudo el caso de los pequeños agricultores pobres, el aumento del precio de los fertilizantes tiene escasas repercusiones en la rentabilidad.
Sin embargo, incluso en sistemas de producción intensiva que utilizan grandes cantidades de fertilizantes, el costo del fertilizante utilizado es mucho menor que el valor bruto de la cosecha producida, siendo la magnitud relativa de estas dos cantidades la que determina el efecto neto del precio de los fertilizantes en la rentabilidad. Por ejemplo, en diversos sistemas de arroz de regadío de rendimiento elevado en seis países de Asia, el valor del fertilizante aplicado fue en general alrededor del $8 \%$ del valor bruto de la producción en 199958 . Esto implica que una duplicación de los precios de los fertilizantes aumentaría los costos de la producción un $8 \%$ del valor de la misma (suponiendo que no se produjeran cambios en la aplicación de los fertilizantes), lo cual significa a su vez que un aumento de los precios de la producción de solo un $8 \%$ mantendría la rentabilidad a un nivel constante. Incluso una duplicación ulterior (es decir, un aumento de cuatro veces en total, como ocurrió en los mercados mundiales de la urea), requeriría únicamente un incremento del $32 \%$ en los precios de la producción para compensar por completo el aumento del costo. Por supuesto, si los precios de los fertilizantes aumentaran considerablemente a largo plazo y el costo de estos productos se acercara al valor bruto de la producción, se requeriría un incremento cada vez mayor de los precios de la producción para compensar dicho costo.

Esta tendencia general es evidente en el Cuadro 2, que muestra la evolución de los costos y beneficios de la producción de arroz de invierno-primavera en la provincia de An Giang, en el delta del Río Mekong de Viet Nam. Entre 2007 y 2008, los costos de los fertilizantes se duplicaron con creces, los de las semillas llegaron casi a duplicarse, los de la mano de obra 


\section{FIGURA 15}

Entre 2001 y 2008, los precios mundiales de los fertilizantes a base de nitrógeno, fósforo y potasio aumentaron más que los precios mundiales del arroz, el trigo y el maíz

\section{Índice $(2001=\mathbf{1 0 0})$}

600

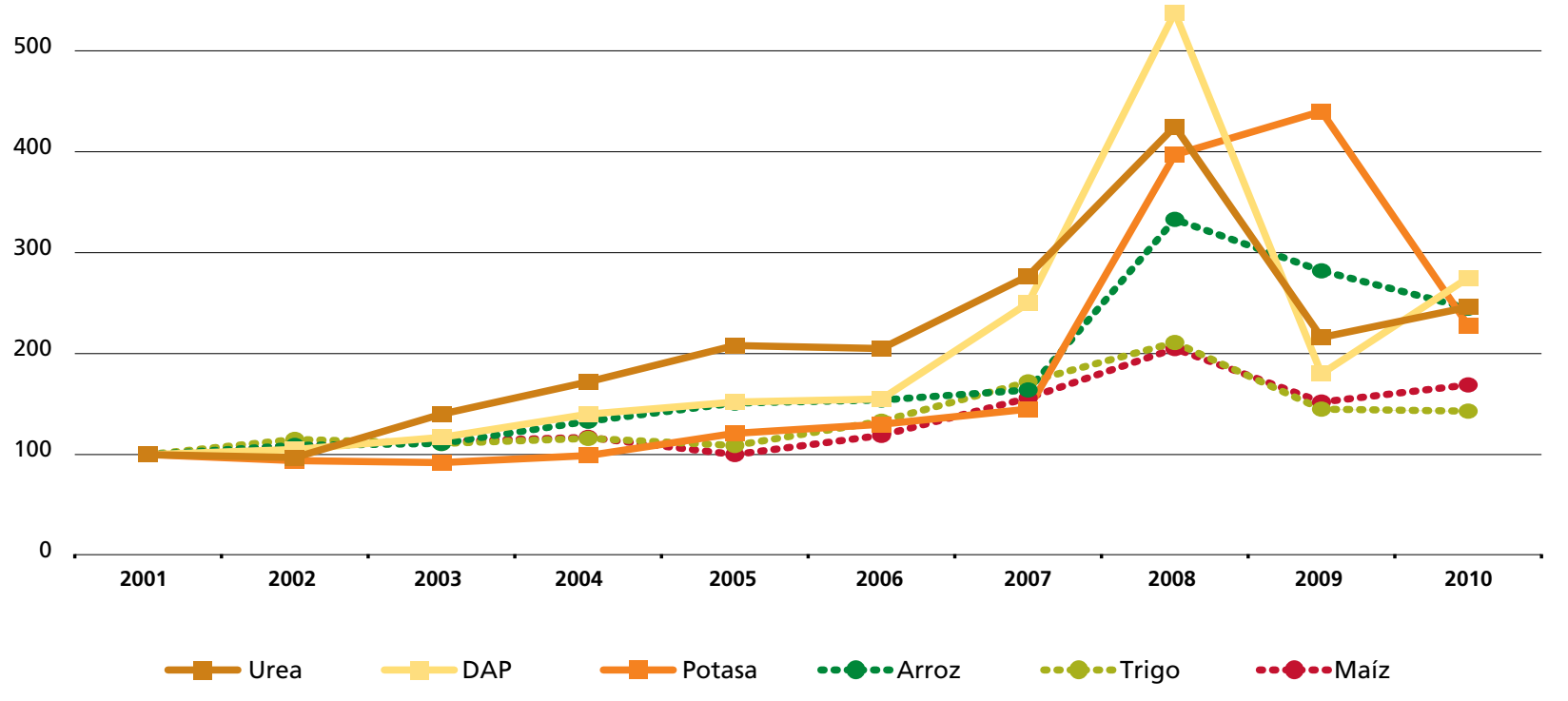

Notas: Índice calculado con arreglo a los precios ajustados en función de la inflación. DAP = bifosfato amónico.

Fuente de los datos primarios: Fondo Monetario Internacional (FMI).

aumentaron considerablemente y los rendimientos cayeron, pero un aumento del $57 \%$ en los precios del arroz cáscara fue suficiente para incrementar los beneficios en un $34 \%$. En Bangladesh, los beneficios de la producción de arroz en 2007/08 se duplicaron con creces en comparación con el año anterior ${ }^{59}$. No es de extrañar, por tanto, que posteriormente cayeran en cada uno de los dos años sucesivos, aunque incluso en 2009/10 eran comparables a los de 2005/06. En Kenya, la combinación de un aumento en torno al $160 \%$ en los precios de los fertilizantes con un incremento del $77 \%$ en los precios del maíz de 2007 a 2008 permitió que se duplicaran con creces los beneficios ${ }^{60}$. Sin embargo, el aumento de los beneficios depende de que se sigan aplicando los fertilizantes; si su empleo se reduce drásticamente porque los agricultores no pueden permitírselos, los rendimientos se reducen y los beneficios pueden también disminuir. Esta situación no se produciría si los mercados crediticios funcionaran bien, pero en numerosas ocasiones no es así.

\section{CUADRO 2}

La rentabilidad del cultivo de arroz cáscara de invierno-primavera en la provincia de An Giang (Viet Nam) aumentó en 2007/08 a pesar del incremento notable del precio de los fertilizantes y las semillas

\begin{tabular}{|c|c|c|c|}
\hline Producto & 2007 & 2008 & Porcentaje de cambio \\
\hline Semilla & 484 & 936 & 93 \\
\hline Fertilizante & 3269 & 6691 & 105 \\
\hline Mano de obra & 3116 & 4765 & 53 \\
\hline Otros costos & 2928 & 2941 & 0 \\
\hline Rendimiento (kg/ha) & 6100 & 5792 & -5 \\
\hline Arroz cáscara (VND/kg) & 2350 & 3700 & 57 \\
\hline Beneficios & 4538 & 6097 & 34 \\
\hline
\end{tabular}

Fuente: Adaptado de P. Hoang Ngan. 2010. The Vietnamese rice industry during the global food crisis. En D. Dawe (editor)

The rice crisis: markets, policies and food security. Londres, Earthscan y Roma, FAO.

Notas: VND = dong de Viet Nam. Costos y beneficios expresados en miles de VND por hectárea. 
La Figura 16 muestra el porcentaje de aumento en los precios de los cultivos necesario para compensar plenamente la duplicación de los precios de los fertilizantes y los combustibles en una gran variedad de sistemas de producción en todo el mundo. (Los costos de los combustibles y los fertilizantes suelen aumentar paralelamente porque el gas natural es un insumo esencial en la producción de fertilizantes de urea). Los sistemas muy mecanizados, o los que se basan en el bombeo de las aguas subterráneas, se verían afectados en mayor medida por la importancia de los costos de los combustibles. Los efectos serían menores en los sistemas de cultivo sin labranza que utilizan agua de riego de superficie o que son de secano. Así, los efectos de los cambios en los precios de los fertilizantes y los combustibles variarían entre los diferentes tipos de sistema de producción, si bien en numerosas ocasiones bastaría con un pequeño aumento en los precios de la producción para compensar incluso un incremento considerable de los de los fertilizantes. En otras palabras, un incremento en la relación entre el precio de los fertilizantes y los precios de la producción no implica necesariamente una disminución de la rentabilidad. De hecho, durante la crisis alimentaria mundial, la respuesta de la oferta parece haber sido muy importante en diversos de países en desarrollo ${ }^{61}$. Los agricultores de los países en desarrollo responden de hecho a los precios más altos incrementando la superficie plantada y el rendimiento ${ }^{62}$, aunque la respuesta se reduce cuando los precios son inestables ${ }^{63}$.
El momento en que tienen lugar las variaciones de los precios también puede ser decisivo. En Viet Nam, en 2008, los agricultores plantaron la cosecha de arroz de verano-otoño cuando el precio del arroz y los fertilizantes eran relativamente altos. El precio elevado del arroz contribuyó a incrementar la superficie plantada, pero en el momento de la cosecha los precios del arroz y los fertilizantes habían disminuido considerablemente (en consonancia con los precios mundiales). Lamentablemente los agricultores tuvieron que vender su producción al nuevo precio más bajo, pero no se beneficiaron de la disminución de los precios de los fertilizantes (al menos no para esa cosecha), ya que los habían comprado y aplicado antes de que los precios bajaran. Por otro lado, la cosecha de invierno-primavera obtenida a comienzos de 2008 se benefició de un aumento notable e imprevisto de los precios del arroz, lo que condujo a un fuerte incremento en los beneficios (Cuadro 2). Por tanto, el factor temporal puede afectar en ambos sentidos.

En resumen, los precios al productor y los beneficios parecen haber aumentado en numerosas ocasiones durante la crisis alimentaria mundial, pero ese incremento fue solo temporal. El aumento de la volatilidad (véase la Figura 6), sumado al hecho de que en el segundo trimestre de 2010 los precios internos en valores reales hubieran vuelto en gran medida a los niveles anteriores a la crisis (Figura 5), comportó que fueran escasos los incentivos para los pequeños agricultores a aumentar la inversión a largo plazo en las explotaciones agrícolas (en contraposición a la respuesta de la oferta a corto plazo).

\section{FIGURA 16}

Un aumento relativamente reducido de los precios de los cultivos puede compensar una duplicación de los precios de los fertilizantes y los combustibles

\section{Aumento de los precios de los cultivos (porcentaje)}

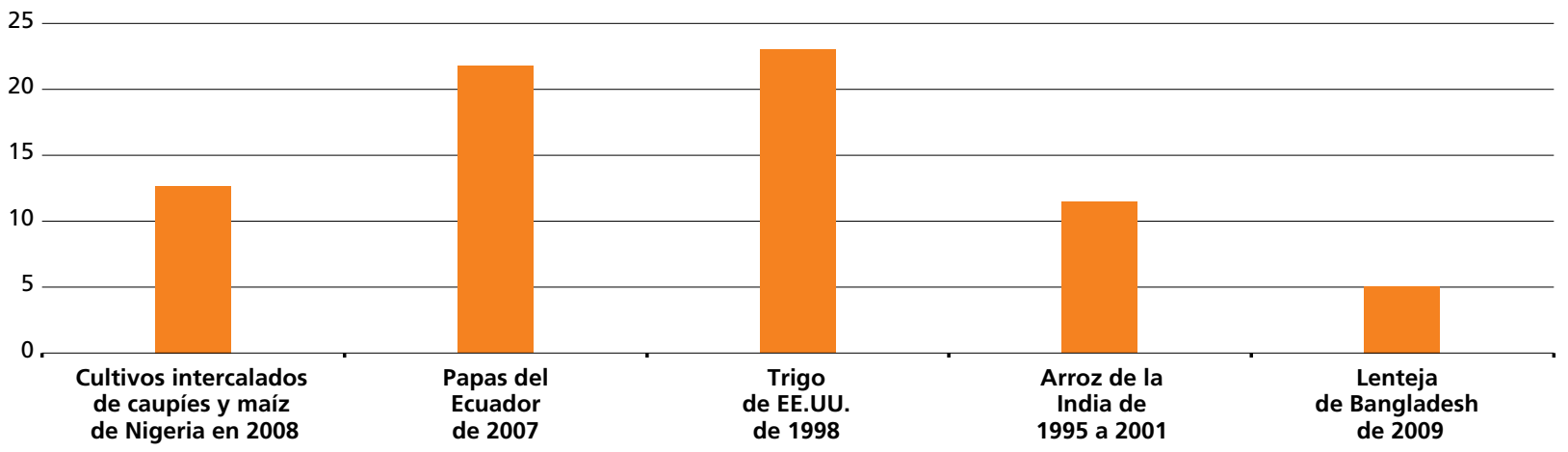

Nota: La Figura muestra el aumento porcentual del precio de los cultivos que sería necesario para mantener los beneficios si los costos de los fertilizantes y los combustibles se duplicaran. El cálculo supone que los costos de las semillas aumentan el mismo porcentaje que los precios de los cultivos, ya que los precios de las semillas suelen incrementar paralelamente a los precios de producción y constituyen una carga adicional para los agricultores.

Fuentes de los datos primarios: M. Ali y G. Vocke. 2002. How wheat production costs vary. En: Wheat Yearbook 2002. Washington, DC, Departamento de Agricultura de los Estados Unidos de América; A. O. Segun-Olasanmi y A. S. Bamire. 2010. Analysis of costs and returns to maize-cowpea intercrop production in Oyo state, Nigeria. Ponencia presentada en la tercera Reunión conjunta de la Asociación Africana de Economistas Agrarios (AAAE) y la 48. ${ }^{a}$ Conferencia de la Asociación de Economistas Agrarios de Sudáfrica (AEASA) celebrada en El Cabo (Sudáfrica) del 19 al 23 de septiembre de 2010; R. Cavatassi, M. González-Flores, P. Winters, J. Andrade-Piedra, P. Espinosa y G. Thiele. 2011. Linking smallholders to the new agricultural economy: the case of the Plataformas de Concertación in Ecuador. Journal of Development Studies (próxima publicación); M. A. Rashid, M. K. Hassan y the new agricultural economy: the case of the Plataformas de Concertación in Ecuador. Journal of Development Studies (próxima publicación); M. A. Rashid, M. K. Hassan y
A. K. M. Harun-ur-Rashid. 2009. Domestic and international competitiveness of production of selected crops in Bangladesh. Informe final CF n. 1/08. Dhaka, Programa nacional de fortalecimiento de la capacidad en materia de políticas alimentarias; B. Vinayakumar, N. Kollurmath, N. Karnool, L. B. Kunnal, H. Basavaraj y V. Kulkarni. 2008. Cost of production of rice and maize in World Trade Organization era of Karnataka. Karnataka Journal of Agricultural Science, 21(2): 241 a 245. 




\section{Opciones en materia de políticas para hacer frente a la volatilidad y los altos precios}

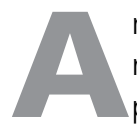

ntes de examinar las posibles intervenciones de reducción y gestión de la volatilidad de los

precios en el mercado interno, hay que señalar que cierta volatilidad es una característica intrínseca de los mercados de productos agrícolas. A corto plazo, su causa es el desfase temporal entre la oferta (que es estacional) y la demanda (que lo es mucho menos); este desfase impone la necesidad de almacenar los productos agrícolas, almacenamiento que solo podrá ser rentable si los precios varían a lo largo del año. A largo plazo, si el incremento de la producción alimentaria no se mantiene a la par con el crecimiento de la demanda, es importante que los precios aumenten. Esto estimulará a los agricultores a aumentar la oferta y será un incentivo para que el sector privado dedique más esfuerzos a la investigación y desarrollo, a la vez que dará la señal al sector público para un incremento del gasto en bienes públicos que respalden la producción agrícola y los mercados.

En términos generales, las intervenciones que buscan reducir los costos asociados a la volatilidad de los precios pueden clasificarse en dos grupos. El primero comprende las medidas dirigidas a reducir dicha volatilidad, por ejemplo la mejora de la información sobre los mercados (Recuadro 7). En el segundo grupo se incluyen aquellas intervenciones que parten de la aceptación de la volatilidad de los precios como un hecho dado y procuran ayudar a hacerle frente. Estos mecanismos de defensa pueden aplicarse tanto a priori, es decir, antes de que la volatilidad se produzca, como a posteriori.

\section{Mejorar los sistemas de información sobre los precios a fin de reducir la volatilidad de los precios}

La información sobre la situación actual y las perspectivas de la agricultura mundial configura la expectativa sobre los precios futuros y permite un funcionamiento más eficiente de los mercados. Por el contrario, la falta de información precisa sobre las variables fundamentales del mercado puede reducir la eficiencia y acentuar las fluctuaciones de los precios. Una información y unos análisis más adecuados sobre los mercados mundiales y locales, sumados a una mayor transparencia, podrían reducir la incidencia y la magnitud de las alzas de los precios provocadas por situaciones de pánico.

Los acontecimientos recientes han revelado las deficiencias de capacidad de las naciones y las organizaciones internacionales para producir en tiempo oportuno datos y análisis sistemáticos y precisos sobre el mercado agrícola, especialmente en respuesta a fenómenos meteorológicos extremos como inundaciones o sequías. Es necesario adoptar medidas para aumentar la capacidad de llevar a cabo un seguimiento frecuente y sistemático del estado de los cultivos, así como idear mecanismos para elaborar pronósticos de la producción a corto plazo más adecuados, que sean capaces de traducir los datos sobre el crecimiento de los cultivos y la información meteorológica y de la teledetección en expectativas sobre el rendimiento y la producción. Se podría hacer un mayor uso de los datos de satélites y de los sistemas de información geográfica; asimismo sería posible, en este contexto, potenciar la coordinación y el intercambio de tecnologías e información en el ámbito internacional.

La información sobre las existencias alimentarias es un componente fundamental del sistema de información 
sobre el mercado mundial de alimentos; sin embargo, ocurre a menudo que no se reúnen datos fiables sobre las existencias de cereales y semillas oleaginosas, o que tales datos se recopilan pero no se les da divulgación pública. Las causas de esta falta de datos fehacientes sobre las existencias son muchas: algunos países ya no mantienen existencias públicas porque han suprimido o reformado las políticas que las establecían; las existencias pueden estar muy dispersas entre los agricultores, los comerciantes y otros agentes, lo que dificulta su seguimiento; por último, ciertas informaciones sobre las existencias quizás se consideren como datos delicados por motivos comerciales o políticos. Generalmente los organismos internacionales elaboran sus cálculos de la variación neta de las existencias a partir de datos relativos a la producción, el consumo y el comercio. La consecuencia es que no es posible confiar por completo en las estimaciones de las existencias mundiales de alimentos. La cooperación internacional podría corregir esta situación y garantizar una amplia disponibilidad de información fiable sobre las existencias mundiales. Esto permitiría a su vez informar mejor a los participantes en el mercado, y ayudaría a evitar alzas de precios inducidas por el pánico a causa de la difusión de informaciones erróneas.

El seguimiento de los precios de los alimentos, tanto en los mercados al contado como en los de futuros, es otro componente fundamental de un sistema de seguimiento del mercado de productos alimenticios. También es importante determinar las variaciones de los precios del petróleo y analizar sus consecuencias para los mercados de alimentos. Se necesita información más adecuada sobre las fluctuaciones de los precios internos a fin de entender mejor de qué forma las fluctuaciones de los precios internacionales afectan a los mercados nacionales de los países en desarrollo. Tal información es importante para sistemas de alerta rápida como el Sistema mundial de información y alerta de la FAO y la Dependencia de Análisis y Cartografía de la Vulnerabilidad del PMA. Es fundamental, asimismo, para la elaboración de políticas y para el diseño de instrumentos eficaces de gestión del riesgo destinados a los países en desarrollo.

En los países en desarrollo, la mejora de los sistemas de información y alerta rápida sobre el mercado permitiría tanto a los gobiernos como al sector privado una planificación anticipada. Los gobiernos estarían en condiciones de evaluar con mayor precisión las necesidades, asignar recursos presupuestarios a redes de seguridad para los productores y los consumidores y dar una localización más idónea a las reservas alimentarias de seguridad para emergencias. Informaciones y análisis más precisos sobre el mercado podrían reducir la incertidumbre y ayudar a los productores, comerciantes y consumidores a adoptar decisiones más correctas.

Durante el último decenio se ha elaborado considerable información de referencia sobre la vulnerabilidad de la seguridad alimentaria. El respaldo del PMA a sistemas nacionales de seguimiento de la seguridad alimentaria ofrece ya un instrumento de seguimiento y apoyo a las decisiones que servirá de ayuda a los gobiernos en la gestión y respuesta a los riesgos relacionados con los precios, los fenómenos meteorológicos u otros peligros. En el plano regional, algunos esfuerzos exitosos como el de la Red del sistema de alerta rápida contra la hambruna han incrementado la información disponible para los gobiernos y para quienes participan en el mercado. Es necesario hacer que tales sistemas de alerta rápida sean más fiables y puntuales, y fortalecer la capacidad nacional y regional para su desarrollo y utilización. La atención debe centrarse en los países especialmente vulnerables a las crisis de precios y las emergencias alimentarias.

La experiencia de la crisis de los precios de los alimentos en 2006-08 y la considerable volatilidad actual de los precios en muchos mercados internacionales de alimentos revelan las deficiencias no solo del suministro de información sobre los mercados en el plano mundial, sino también de la coordinación de la respuesta normativa a la volatilidad de los precios alimentarios. Es preciso asegurar una preparación más adecuada y una respuesta más rápida y coherente de las políticas en tiempos de crisis. Partiendo de los sistemas existentes, y complementándolos, se podrían lograr mejoras en la información mundial sobre el mercado y la orientación normativa pertinente; varias organizaciones internacionales tienen en examen, a tal efecto, una iniciativa de colaboración sobre información y políticas alimentarias, el Sistema de información sobre los mercados agrícolas (AMIS). Tal iniciativa aumentaría la fiabilidad, puntualidad y frecuencia de los datos y potenciaría la coordinación de las políticas en épocas de crisis.

El AMIS se podría construir siguiendo el modelo de la Iniciativa Conjunta de Datos sobre Petróleo emprendida en el año 2000 con objeto de mejorar la información sobre los mercados petroleros. Tendría, además, las funciones de emitir alertas mundiales sobre alzas de precios de los alimentos y de promover la coherencia de las políticas. Participarían en este sistema los principales países productores, exportadores e importadores de alimentos. La iniciativa contaría además con una secretaría integrada por las organizaciones internacionales que cuentan con capacidad para recopilar, analizar y divulgar en forma sistemática informaciones sobre la situación y las perspectivas del suministro de alimentos, así como para formular políticas alimentarias. 
Además, pueden ser aplicados tanto en el ámbito internacional como interno, por el sector público o por el privado. Por otra parte, algunas intervenciones pueden colocarse en más de una de estas categorías. Por ejemplo, el uso de reservas internas de estabilización y los mecanismos de control del comercio aceptan la volatilidad de los precios como un dato de hecho e intentan hacerle frente a posteriori, lo cual no quita que al mismo tiempo intenten reducir la volatilidad de los precios en el mercado interno.

Hay algunos principios básicos que deberían tomarse en cuenta a la hora de formular las intervenciones. Primero: pese a la dificultad para cuantificar los costos y beneficios de las distintas políticas, es importante que al idear las intervenciones se tenga en cuenta, siempre que sea posible, su eficacia respecto a los costos. Esta tiene importancia a fin de asegurar la disponibilidad de fondos públicos para las fundamentales inversiones en investigación agrícola, carreteras, educación y salud.

Segundo: hay que tener en cuenta que el sector privado desempeñará un papel decisivo y dominante en un sistema de comercialización eficaz, que se define como aquel que ofrece los precios más elevados a los productores y los más bajos a los consumidores. No existe ningún ejemplo de un sistema eficaz de comercialización de productos alimenticios que esté dominado por el sector público.

Tercero: aunque es probable que en el futuro continúen las intervenciones de los gobiernos en el mercado, estas deberían volverse más previsibles y tener en cuenta el efecto que producen en el comportamiento del sector privado. Cuando la intervención pública no sigue una línea clara no solamente aumenta los costos para el sector privado, obstaculizando así su desarrollo, sino que suele provocar un incremento de la volatilidad de los precios. Existen varios ejemplos de medidas gubernamentales que han desalentado las operaciones de importación del sector privado, provocando así el alza de los precios internos ${ }^{64}$.

Cuarto: además de los principios generales antes mencionados, hay que considerar que cada país tiene, en muchos sentidos, características únicas. A fin de tomar en cuenta las diferentes situaciones deberá, por tanto, analizar sus circunstancias peculiares y emprender las políticas apropiadas para ellas. Debería alentarse una experimentación específica conforme a estas pautas que se adapte a las condiciones nacionales.

\section{Prevenir la volatilidad de los precios internos a corto plazo: políticas comerciales y reservas de estabilización}

\section{Mensaje principal}

Unas políticas gubernamentales más previsibles y que promuevan la participación del sector privado en el comercio disminuirán, en general, la volatilidad de los precios. La mayor previsibilidad para los comerciantes privados disminuirá el riesgo y esto se traducirá en márgenes más estrechos, menores precios para los consumidores y precios más altos para los agricultores.

Históricamente muchos países, tanto desarrollados como en desarrollo, se han preocupado por reducir la volatilidad de los precios internos. Para alcanzar este objetivo, los países en desarrollo han recurrido habitualmente a una combinación de controles del comercio y existencias estabilizadoras.

Como se ha señalado antes, la volatilidad de los precios puede tener su origen tanto en los mercados internos como internacionales. Así pues, una política completa sobre el tema no puede ocuparse exclusivamente de las crisis de los precios internacionales, sin tener en cuenta las perturbaciones del suministro interno. En general, el comercio es el medio más eficaz para estabilizar los precios internos ante una crisis de la oferta en el mercado interno. Sin embargo, para que el comercio sea más eficaz es fundamental contar con un sistema sólido de información sobre el mercado a fin de que las importaciones puedan disponerse en tiempo oportuno, sea que las concierte el gobierno o el sector privado. Si la llegada de los productos importados o el acceso a reservas humanitarias de emergencia se van a retrasar de forma considerable, las existencias estabilizadoras pueden desempeñar un papel importante.

Si la crisis de precios se origina en el mercado mundial, los países tendrán fundamentalmente dos opciones (con sus posibles combinaciones): 
- Aceptar la volatilidad de los precios y enfrentarla mediante una combinación de instrumentos de gestión de riesgos y redes de seguridad.

- Utilizar una combinación de medidas de control del comercio y existencias estabilizadoras para reducir la repercusión de los precios de los mercados internacionales.

Ambas opciones tienen sus costos. Los costos de la volatilidad, que se han descrito anteriormente en "Costos y beneficios de los precios volátiles e imprevisibles", pueden ser sustanciales. Por otra parte, las existencias estabilizadoras y los controles del comercio también tienen sus costos. Por ejemplo, las existencias estabilizadoras pueden entrañar considerables costos financieros. Además, el mantenimiento de existencias de estabilización a un nivel determinado puede entrañar intercambios anuales de un volumen equivalente al doble a fin de mantener la calidad de las existencias. Estos intercambios representan costos de transacción significativos (o el deterioro de la calidad si tales intercambios no se llevan a cabo). Las intervenciones públicas dirigidas a estabilizar los precios internos incrementan la volatilidad de los precios mundiales y perjudican a los países más pobres y más pequeños, que dependen en gran medida de la importación de alimentos. Si los controles del comercio reducen los precios internos, la respuesta será una oferta inferior a la que se hubiera producido en otras condiciones. Esto puede crear problemas graves si los controles se mantienen a lo largo del tiempo, porque la mayoría de los observadores prevén precios mundiales más altos en el futuro y, si esto se verifica, el mundo necesitará mayores suministros ${ }^{65}$.

En conjunto, no es fácil determinar si los costos de la volatilidad de los precios son mayores o menores que los de las intervenciones dirigidas a evitarla; la respuesta dependerá, sin duda, de cada situación específica. No obstante, sobre la base de la experiencia histórica así como de los conocimientos teóricos es posible proporcionar unas directrices para ayudar a reducir los costos de las intervenciones gubernamentales.

Algunos países asiáticos productores de arroz han utilizado, para estabilizar los precios, una combinación de comercio internacional, existencias estabilizadoras, monopolios de la importación o la exportación y compras en el mercado interno. Estas medidas a menudo han resultado eficaces para lograr los objetivos buscados, y en algunos casos también pueden haber estimulado el crecimiento económico (véase el Recuadro 8). En África, la experiencia relativa a la estabilización del mercado del maíz es menos positiva porque las intervenciones han sido, en muchos casos, poco previsibles, y han dado menos respaldo a un papel importante del sector privado en las actividades de comercialización.
Los comerciantes privados han tenido que hacer frente a incertidumbres relacionadas con muchos factores importantes, a saber:

- la emisión de licencias de importación y exportación;

- la cuantía del arancel y los grupos de comerciantes privados que podrían estar exentos del mismo;

- el volumen de las importaciones del gobierno y el precio al que se venderán;

- la observancia de las normas sanitarias y fitosanitarias:

- $\quad$ el transporte a través de las fronteras nacionales.

En su conjunto estas incertidumbres acrecientan considerablemente el riesgo del mercado, desalientan la inversión privada indispensable para el buen funcionamiento del mercado y exponen a muchas economías a un riesgo innecesario de escasez de alimentos. Las políticas gubernamentales deben ser relativamente transparentes y previsibles a fin de que el sector privado pueda desempeñar su función en lo que atañe a desplazar suministros de las zonas con excedentes a las que tienen déficit y almacenar existencias entre el momento de la cosecha y el período de escasez. Además, dichas políticas deberían hacer lo más posible por reducir al mínimo los costos, a fin de garantizar que los presupuestos agrícolas se destinen sobre todo a inversiones en investigación y otros bienes públicos capaces de proporcionar soluciones a largo plazo a la volatilidad de los precios.

En muchos casos, las políticas gubernamentales sobre comercio de alimentos parecen inspirarse en la desconfianza en los comerciantes privados.

Una medida fundamental que podría adoptarse en muchos países es el establecimiento de canales abiertos, regulares y oficiales de comunicación entre el gobierno y el sector privado. Esto permitiría incrementar la transparencia y podría ayudar a evitar las crisis, al alertar por anticipado sobre problemas inminentes que podrían amenazar la seguridad alimentaria de la población pobre ${ }^{66}$.

El comercio internacional tiene un papel fundamental que cumplir en la reducción de la volatilidad de los precios internos, pero el hecho de que las normas de la Organización Mundial del Comercio sean mucho menos estrictas en lo que atañe a los obstáculos a la exportación que a las restricciones de la importación es un grave impedimento para el aumento de la confianza en los mercados internacionales. De hecho, en los últimos años, las restricciones a la exportación han exacerbado la volatilidad de los precios en los mercados internacionales (véase el Recuadro 8). Los importadores netos de alimentos necesitan garantías mucho mayores de sus asociados comerciales si han de confiar en el comercio internacional como fuente de alimentos. La opción ideal consistiría en prohibir por completo las 


\section{La estabilización de los precios del arroz en Indonesia}

Indonesia consiguió mantener estables los precios del arroz en su mercado interno durante más de un cuarto de siglo, desde 1969 hasta 1996 (véase el gráfico que figura más abajo). Durante ese período los precios internos fueron, en promedio, aproximadamente iguales a los mundiales, pero considerablemente menos volátiles. La estabilización se consiguió combinando el comercio internacional (por lo general importaciones, pero ocasionalmente también exportaciones) con existencias reguladoras que se compraban y distribuían en función de la presencia de excedentes o déficit de producción'. Si bien la cantidad de arroz adquirida por el Gobierno varió de año en año en función del volumen de la cosecha, en promedio fue inferior al $5 \%$ de la producción interna. En otros términos, la comercialización del $95 \%$ de la cosecha arrocera estuvo a cargo del sector privado. Además, casi todas las adquisiciones efectuadas por el Gobierno se realizaron a través de intermediarios y no mediante compras directas a los agricultores.

Cada año se anunciaba un precio mínimo antes de la siembra de la campaña agrícola principal, con lo que se ofrecía a los agricultores un incentivo claro para la adopción de nuevas tecnologías. El precio mínimo anunciado se establecía teniendo en cuenta las tasas de inflación y se ajustaba ligeramente al alza o a la baja en función de las fluctuaciones de los precios mundiales, así como de los precios de los fertilizantes y otros factores. Una vez ajustado en función de la inflación dicho precio mínimo se mantenía relativamente estable a lo largo del tiempo, lo que suponía un incentivo a largo plazo para invertir en la producción de arroz. Los beneficios globales de la estabilización del precio del arroz fueron considerables, aunque con el tiempo se fueron reduciendo al disminuir, con el crecimiento económico, la importancia para la economía del arroz ${ }^{2}$.

\footnotetext{
${ }^{1}$ C. P. Timmer. 1996. Does BULOG stabilize rice prices in Indonesia? Should it try? Bulletin of Indonesian Economic Studies, 32: 45-74.

${ }^{2}$ C. P. Timmer. 2002. Agriculture and economic growth. En B. Gardner y G.Rausser, eds. Handbook of agricultural economics. Vol. IIA, págs. 1487-1546. Ámsterdam, Holanda Septentrional.
}

\section{Indonesia logró estabilizar el precio interno del arroz en el período de 1969 a 1996 a través del comercio} y las existencias reguladoras

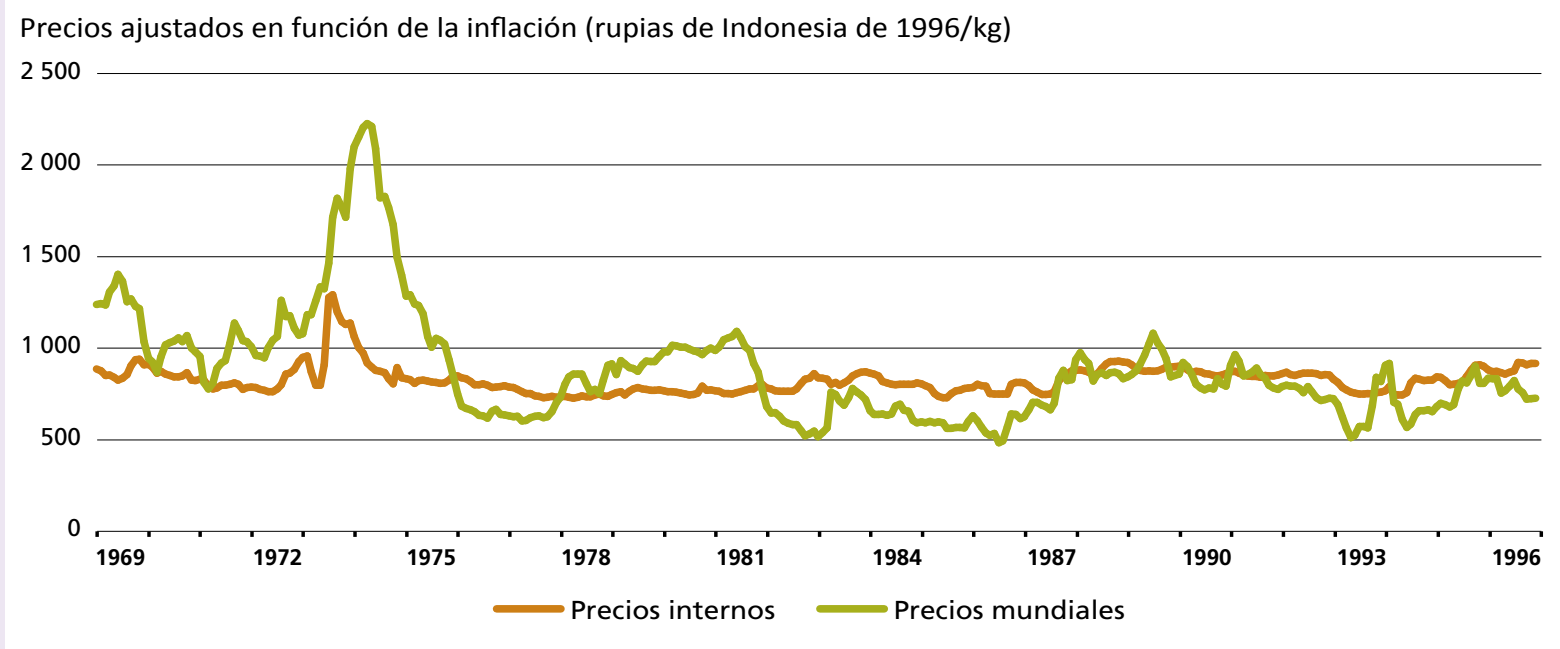

restricciones a la exportación y dejar que los países aborden las cuestiones relacionadas con la seguridad alimentaria nacional mediante medidas de apoyo directo selectivo. Sin embargo, es improbable que pueda lograrse un acuerdo sobre una tal prohibición; además, incluso si se acordara es muy difícil que tal prohibición se haga cumplir durante una crisis alimentaria. Es posible y útil, por otra parte, reforzar las reglas, especialmente en lo que atañe a la transparencia. 


\section{La crisis mundial del arroz}

La volatilidad de los precios en los mercados internacionales puede, a veces, ser consecuencia de políticas de intervención en el mercado interno; la crisis mundial del arroz de 2007/08 ofrece un útil estudio de caso al respecto.

La crisis del arroz no se derivó de problemas relacionados con el equilibrio fundamental entre producción y consumo. En primer lugar, la producción arrocera se mantuvo los incrementos de la demanda en los años previos a la crisis, y en 2007/08 no se verificaron trastornos importantes de la oferta; de hecho, la producción mundial de arroz alcanzó nuevos niveles récord durante cuatro años seguidos a partir de 2005. En segundo lugar, gracias a los buenos resultados productivos la relación entre existencias y utilización se mantuvo generalmente constante durante los tres años que precedieron la crisis, sin reducciones que determinaran la vulnerabilidad del mercado a pequeños trastornos de la producción. En tercer lugar, pese a la preocupación porque ciertos exportadores no querían vender (previendo, quizás, que el aumento de los precios continuaría), los importadores pudieron disponer de suministros en los mercados internacionales; el volumen de las exportaciones durante los cuatro primeros meses de 2008 fue aproximadamente un $20 \%$ más alto que en el mismo período de 2007.

Mientras que los elementos fundamentales del mercado del arroz eran firmes, los mercados de otros productos alimenticios tendían al aumento de los precios. El incremento de la demanda de biocombustibles obtenidos a partir del maíz y las semillas oleaginosas, sumado a una reducción del $4 \%$ de la producción mundial de trigo en 2006/07 (entre otras cosas a causa de una grave sequía en Australia, uno de los principales exportadores de este cereal), hizo crecer los precios en dichos mercados. Es probable que los precios más elevados del maíz y el trigo hayan inducido a algunos consumidores a comprar arroz en lugar de trigo, lo que habría ejercido cierta presión alcista sobre los precios del arroz. Sin embargo, el incremento de los precios del arroz fue mucho mayor de lo que podría haberse explicado por esa sustitución; en última instancia fueron las políticas gubernamentales las que provocaron la crisis. De hecho, la subida de los precios fue más rápida y mayor en el caso del arroz que en el de los cereales con condiciones de mercado menos favorables.
Además de los precios más altos del maíz y el trigo, también el aumento de los precios petroleros y la debilidad del dólar estadounidense contribuyeron al incremento general de los precios de los productos básicos. Dichos factores suscitaron en algunos países el temor de que también pudieran aumentar los precios del arroz. En realidad los precios de este cereal venían incrementándose desde 2003, pero en esos años su aumento había sido relativamente lento y constante (y, por tanto, fácil de gestionar). Sin embargo, a partir de octubre de 2007 las políticas gubernamentales de diversos países hicieron que los precios se incrementaran con rapidez. Los grandes productores de arroz restringieron la oferta en el mercado mundial a fin de evitar escaseces para sus consumidores, recurriendo para ello ya sea a prohibir por completo las exportaciones o a anunciar precios de exportación mínimos cada vez más elevados. Los gobiernos de los países importadores de arroz se esforzaron por conseguir suministros para estabilizar sus mercados, a menudo mediante la compra de cantidades muy grandes que pagaron a precios superiores a los del mercado. Otros anunciaron planes de acumulación de existencias durante la crisis, con lo que se acrecentó aún más la demanda. Como consecuencia de esas políticas, entre octubre de 2007 y abril de 2008 los precios de los mercados mundiales se triplicaron. Cabe señalar que, incluso durante la crisis alimentaria mundial de 1973-1975, los precios mundiales del arroz nunca habían llegado a duplicarse en seis meses y menos aún a triplicarse.

Si bien las restricciones comerciales permitieron a algunos países evitar que la brusca alza de los precios en los mercados internacionales se repercutiera en sus precios nacionales, la estabilidad interna se consiguió al costo de desestabilizar el mercado mundial. Con toda probabilidad la crisis del arroz no se hubiera producido de no haberse adoptado estas medidas. Por consiguiente, una enseñanza de la crisis de los precios arroceros es la necesidad de fortalecer las disciplinas de la Organización Mundial del Comercio a fin de que se haga un uso menos frecuente de las restricciones a la exportación. Por otra parte, como se ha señalado antes, cualquiera de esas disciplinas puede revelarse difícil de hacer cumplir. 


\section{RECUADRO 9 (Cont.)}

Otro planteamiento para estabilizar el mercado arrocero mundial es el de reducir el efecto perjudicial de las restricciones al comercio. Un paso importante en esta dirección consistiría en aumentar la previsibilidad de las políticas gubernamentales. Aunque muchos gobiernos tienen el comprensible deseo de mantener cierta flexibilidad en cuanto a la forma de responder a acontecimientos imprevistos, se podrían evitar ciertos cambios de las políticas. Otros podrían aplicarse con arreglo a un calendario anunciado previamente o a criterios para determinar en qué momento se introducirán en forma automática ciertos cambios en respuesta a acontecimientos externos; esto haría que las fluctuaciones de los precios fueran más previsibles.
La crisis de los precios demuestra también la necesidad de fortalecer el papel del sector privado en la actividad comercial incluso cuando son los gobiernos los que determinan en qué momento tendrá lugar el comercio. Es poco probable que los comerciantes del sector privado abonen precios superiores a los del mercado; además, sus volúmenes comerciales, al ser más pequeños, difícilmente provocarán desplazamientos del mercado. Ampliar la función del sector privado es particularmente importante para el mercado mundial de arroz que, al ser más pequeño que los mercados mundiales de otros cereales, puede más fácilmente ser influenciado por las grandes transacciones de los gobiernos.

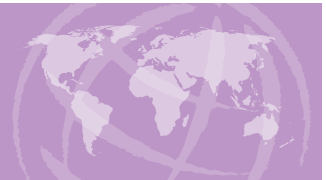

\section{Cómo hacer frente a la probable volatilidad futura de los precios: la gestión de riesgos para los pequeños agricultores y los gobiernos}

\begin{abstract}
Mensaje principal
Se necesitan con urgencia investigaciones agrícolas y sistemas de riego eficaces con respecto a los costos a fin de reducir los riesgos para los campesinos, especialmente los pequeños agricultores. Este tipo de inversión reducirá la volatilidad de los precios y también hará descender los costos de producción por tonelada, lo que a su vez determinará la disminución de los precios de los alimentos.
\end{abstract}

Los agricultores están expuestos a riesgos relacionados tanto con la producción como con los precios. Ambos deben ser contemplados en una estrategia prudente de gestión de riesgos, sobre todo porque uno de ellos puede compensar al otro en determinadas circunstancias (por ejemplo, una crisis de la oferta interna puede hacer crecer los precios, de manera que la reducción de la producción se compensaría por los precios más elevados).

Las condiciones climáticas adversas, así como las plagas y enfermedades, reducen los ingresos agrícolas y hacen que la producción sea más variable. Es probable que en el futuro el cambio climático incremente estos tipos de riesgo. Muchas tecnologías, como la introducción de variedades resistentes a enfermedades y factores adversos o la construcción de sistemas de riego y drenaje, están en condiciones de reducir el riesgo al que se ven expuestos los agricultores. Por ejemplo, en las zonas de Asia donde son frecuentes las inundaciones se está difundiendo con rapidez el empleo de trigo resistente a la inmersión. Otro sistema promisorio para reducir el riesgo con que se enfrentan los agricultores es el empleo de tecnologías mejoradas de almacenamiento en pequeña escala que están al alcance de los pequeños agricultores y los consumidores ${ }^{67}$. Esas tecnologías reducirían las pérdidas después de la cosecha y también permitirían amortiguar el efecto de las crisis de precios, con lo que podría reducirse la posibilidad de alzas de la demanda provocadas por el pánico. Las tecnologías mencionadas constituyen el medio más importante para reducir el riesgo con que se enfrentan los agricultores y los países, por lo que deberían recibir el firme respaldo de los gobiernos nacionales y de los donantes.

Los mecanismos de seguros basados en el mercado son otro posible instrumento para la transferencia del riesgo y para ayudar a los agricultores a adoptar sus decisiones con respecto a la producción. No obstante, hay que considerar que cualquier seguro que sea viable desde el punto de vista 
comercial que se ofrezca como un producto aislado reducirá, a corto plazo, el nivel promedio de los ingresos agrícolas, ya que ninguna compañía privada de seguros ofrecerá un producto que paga sistemáticamente más de lo que recibe. Sin embargo, a largo plazo la reducción del riesgo para los agricultores puede alentarles a invertir en tecnologías más rentables, que aumenten su productividad y sus ingresos. Por ejemplo, si el seguro se combina con créditos, insumos y otros servicios, puede permitir a las familias correr un riesgo prudente sabiendo que estarán protegidos en caso de que ocurra una catástrofe. Los gobiernos pueden (y a menudo lo hacen) otorgar subvenciones destinadas a seguros, pero por lo general estos programas han tenido costos de funcionamiento muy elevados incluso en los países en desarrollo. Es preciso evaluar las subvenciones otorgadas a dichos programas en función de los costos y beneficios de los gastos en investigación agrícola y riego.

Se están destinando muchos esfuerzos y un volumen considerable de investigación a elaborar posibles formas de responder a los retos que entraña el asegurar a los pequeños agricultores contra los riesgos productivos. Los seguros agrícolas basados en índices climáticos son una de estas innovaciones. Con este tipo de seguros, los agricultores reciben un pago cuando determinados factores climáticos -como precipitaciones o temperaturas extremas - superan un cierto umbral y, por tanto, es probable que provoquen una reducción considerable de las cosechas. Estos factores se miden en estaciones meteorológicas, o incluso mediante tecnología de satélites. La ventaja de este sistema es que los aseguradores no necesitan llevar a cabo evaluaciones sobre el terreno, lo cual reduce los costos administrativos. Además, con una póliza de este tipo los agricultores no tienen incentivos para la mala gestión intencional de sus cultivos (un problema conocido como "riesgo moral") a fin de recibir un pago, ya que este se basa en una medición externa y no en el rendimiento de sus cultivos.

Sin embargo, para estipular un seguro basado en índices climáticos debe cumplirse una serie de condiciones. En primer lugar, el índice elegido debe guardar una estrecha correlación con los rendimientos locales, porque de lo contrario los agricultores no se estarán asegurando contra el riesgo pertinente (o "riesgo básico"). En segundo lugar, se debe poder contar con infraestructura adecuada, como una red de estaciones meteorológicas locales u opciones de teledetección disponibles, datos históricos fiables y un entorno legal y reglamentario adecuado. En tercer lugar, los agricultores deben entender con claridad cómo funciona este tipo de seguro y estar en condiciones de pagarlo. Por último, para que el seguro basado en índices sea eficaz, debería estar vinculado a otros servicios financieros como parte de un conjunto más amplio de soluciones de gestión de riesgos.

Actualmente parece más problemático que los pequeños agricultores de los países en desarrollo utilicen los mercados de futuros para la gestión del riesgo relacionado con los precios. Pocos países en desarrollo disponen de bolsas de productos básicos en las que los agricultores y otros actores del mercado puedan resguardarse contra las fluctuaciones de los precios. Además, la participación en esos mercados tiene costos fijos considerables relacionados con el conocimiento y la comprensión necesarios, cuya adquisición resultará menos rentable para un agricultor que posea una finca pequeña. Incluso en los Estados Unidos de América, en 2008 solo el $3 \%$ de los agricultores utilizó contratos de futuros ${ }^{68}$. En general ha resultado sumamente difícil llegar a los pequeños agricultores de una forma eficaz con respecto a los costos.

Los gobiernos se enfrentan con riesgos similares a los de los agricultores, y también son parecidos algunos de los instrumentos de que disponen. Por ejemplo, los seguros basados en índices climáticos se utilizaron por primera vez a nivel nacional en Etiopía en 2006 y en Malawi en 2008 para la gestión de los riesgos productivos y aún se hallan en funcionamiento. Dado el carácter técnico de tales sistemas basados en el mercado para la gestión de la volatilidad de los precios, se hace necesario establecer instituciones de alcance nacional y desarrollar la competencia técnica especializada dentro de las mismas.

Los principales instrumentos que se podrían utilizar para controlar la volatilidad de los precios de las importaciones alimentarias son los contratos de futuros y opciones de compra. Al adquirir contratos de futuros, un gobierno que desea protegerse contra una posible alza de los precios cerealeros bloquea un precio acordado en el momento en que se concierta el contrato. Los contratos de futuros otorgan al país una mayor certidumbre con respecto al precio que abonará por los cereales, pero no ofrecen flexibilidad. Si los precios del mercado descienden el gobierno deberá, de todas formas, pagar el precio acordado, que será más alto del que hubiera abonado de otra forma. En los países pobres esto ocasiona, además de pérdidas financieras, considerables dificultades políticas. En la práctica, los futuros pueden no ser un instrumento útil para los gobiernos, puesto que el elegir una opción de futuros entraña una obligación imprevisible y potencialmente elevada.

Los contratos de opción de compra bloquean un precio máximo, pero no entrañan la obligación de comprar a ese precio elevado si los precios del mercado han descendido. Se trata de una opción atractiva si el objetivo es proteger a un país importador de alimentos contra el alza de los precios, puesto que de esta forma el país seguirá teniendo la posibilidad de beneficiarse si los precios descienden tras la firma del acuerdo. Por consiguiente, una opción de compra brinda mayor flexibilidad que un contrato de futuros. Por otra parte, esta flexibilidad tiene un costo: los contratos de opción de compra son más caros que los de futuros, y es necesario que los gobiernos estén dispuestos a pagar el sobreprecio. En función de su situación fiscal concreta, algunos gobiernos podrán optar por un autoseguro, de forma tal que pagarán ocasionalmente precios elevados pero evitarán abonar año tras año los derechos exigidos para la adquisición de opciones de compra. 


\section{¿Qué ocurre con las operaciones del Programa Mundial de Alimentos de las Naciones Unidas - el mayor comprador de alimentos para fines humanitarios-cuando los precios de los productos alimenticios aumentan?}

El aumento de los precios de los alimentos afecta al Programa Mundial de Alimentos (PMA) de dos maneras: hace que resulte más caro comprar productos alimenticios para los programas en curso destinados a alimentar a los hambrientos y acrecienta el número de las personas que necesitan ayuda alimentaria.

El modelo operativo del PMA es único dentro del sistema de las Naciones Unidas. Se financia por completo mediante donaciones voluntarias y no recibe cuotas asignadas, financiación básica ni derechos de participación de sus miembros. Por este motivo, y por su propia constitución, el PMA no está en condiciones de protegerse contra la variación de los precios de los productos básicos en el mercado como podría hacerlo una gran empresa privada.

Dos factores principales determinan los costos para el PMA. El primero son los precios de los propios productos alimenticios. El PMA adquiere esos productos en los mercados al contado. Por consiguiente, cuando se produjo la crisis de los precios de los alimentos en 2007 el PMA estuvo completamente expuesto al efecto de esos incrementos. Cada aumento de $10 \%$ del costo de la cesta de productos alimenticios del PMA incrementa aproximadamente en 200 millones de USD el costo de la alimentación proporcionada a los beneficiarios.

El segundo factor determinante del costo es el transporte, que a su vez está vinculado a los precios de los combustibles. Dada la necesidad de transportar los alimentos hasta algunas de las zonas más remotas del planeta, incluso lanzándolos desde aviones en los terrenos más difíciles, los precios del combustible influyen considerablemente en los costos del PMA.

Entre junio de 2007 y febrero de 2008 se incrementó en 775 millones de USD el costo requerido para satisfacer las necesidades de todos los beneficiarios de las actividades del PMA en curso en ese momento.

El otro aspecto es la obtención de recursos para atender a las necesidades de los que han comenzado a depender de la ayuda alimentaria justamente a causa del alza de los precios locales de los alimentos. Entre junio de 2007 y febrero de 2008 el PMA necesitó 186 millones de USD adicionales para ampliar sus actividades de asistencia y alimentación en escuelas en beneficio de 4,8 millones de personas en 11 países, distribuir alimentos especiales a alrededor de 1,8 millones de niños malnutridos y mujeres embarazadas o madres lactantes, extender los programas de obras públicas con objeto de que más de 4 millones de beneficiarios tuvieran la posibilidad de llevar alimentos a su mesa, e introducir programas de transferencias de efectivo y cupones de alimentos para que unas 800000 personas en siete países tuvieran acceso a los alimentos disponibles en el mercado.

Se consiguió ahorrar recursos introduciendo cambios en ciertas cestas de alimentos, por ejemplo mediante la sustitución de maíz por sorgo en algunos lugares de África. Pese a ello, los costos adicionales para el PMA en 2008 sumaron en total 920 millones de USD.

El reto final con que tuvo que enfrentarse el PMA en 2007 y 2008 fue el de la compra efectiva de los alimentos. A medida que los mercados de productos alimenticios se restringían, surgieron dificultades para conseguir los alimentos y hacerlos llegar al lugar adecuado en tiempo oportuno. En promedio pasan de tres a cuatro meses desde que se obtienen los productos alimenticios hasta que se entregan en el lugar donde se necesitan. El PMA procura comprar los alimentos mediante procedimientos competitivos, lo más cerca posible del lugar donde dichos productos se requieren, teniendo en cuenta tanto el costo del producto como el del transporte. En 2010 adquirió el $78 \%$ de los alimentos que necesitaba en países en desarrollo. Sin embargo, las dificultades se exacerbaron a causa de que más de 30 países impusieron prohibiciones de exportación de alimentos en un esfuerzo por proteger a sus consumidores. Por más que las exportaciones con fines humanitarios suelan estar exentas de tales prohibiciones, insumió un tiempo considerable el proceso de negociación con los distintos gobiernos cada vez que el PMA tropezaba con una prohibición.

\section{¿Qué respuesta está dando el PMA?}

Antes de la crisis de los precios de los alimentos, el PMA no estaba en condiciones de adquirir productos alimenticios previamente a la recepción efectiva de una contribución de un donante. Después de la crisis de los precios alimentarios de 2008, la Junta Ejecutiva del PMA pasó rápidamente a otorgar autorización para que se dispusiera por adelantado la compra y colocación de alimentos destinados a poblaciones vulnerables una vez asumido un compromiso financiero. Se estableció un mecanismo de compras a término, con un fondo de 
60 millones de USD, para permitir la compra de productos y el pago de los costos de su envío antes de la recepción de las contribuciones de los donantes.

Actualmente el PMA planea ampliar este sistema con miras a potenciar la planificación y las compras anticipadas; se propone incluir en él el establecimiento anticipado de existencias en lugares pertinentes con miras a su rápida entrega a las poblaciones vulnerables afectadas por crisis alimentarias, con el respaldo de un mecanismo rotatorio de financiación ampliado de 150 millones de USD Las existencias se situarán a lo largo de ocho corredores humanitarios principales. Aunque este mecanismo no permite al PMA protegerse de las variaciones del precio de los productos básicos o del riesgo relacionado con los tipos de cambio, hace posible abreviar el tiempo que transcurre entre la determinación de las necesidades alimentarias, la obtención de los recursos financieros y la entrega de los productos alimenticios a las poblaciones necesitadas.



\section{Cómo hacer frente a la volatilidad de los precios cuando ya existe: redes de seguridad selectivas y reservas alimentarias de emergencia}

\author{
Mensaje principal \\ Para lograr la reducción efectiva de las consecuencias \\ adversas de la volatilidad de los precios es necesario \\ elaborar por anticipado mecanismos de redes de \\ seguridad selectivas en consulta con los grupos de \\ población más vulnerables.
}

Las alzas de los precios alimentarios y los incrementos de los de insumos tales como los fertilizantes reducen los ingresos de los hogares pobres y vulnerables y someten a dura prueba los presupuestos familiares. En tales condiciones, las familias venden sus bienes, retiran a los niños de la escuela o modifican su dieta, introduciendo en ella ingredientes menos nutritivos y más baratos; todo esto tiene consecuencias que persisten hasta mucho después de que los precios de los alimentos hayan decrecido. El carácter duradero de estas consecuencias justifica, tanto desde el punto de vista humanitario como económico, el establecimiento de redes de seguridad que mitiguen los efectos de la crisis. Los programas de alimentación escolar, por ejemplo, pueden ayudar a evitar que los niños abandonen la escuela durante una crisis, con lo que se reducirá el efecto a largo plazo de la conmoción de los precios sobre el capital humano.

La potenciación de las redes de seguridad existente es una opción viable para los consumidores pobres en aquellos países que cuentan ya con dichas redes. Esto podría lograrse mediante la incorporación de nuevos beneficiarios, el aumento de las transferencias de recursos a quienes ya se benefician de la red, o por ambos medios. Sin embargo, tales redes de seguridad insumen ingentes recursos. Esto comporta un obstáculo sobre todo para los países en desarrollo de ingresos bajos, que no están en condiciones de abordar tales gastos en tiempos de crisis. Habrá que movilizar rápidamente apoyo externo a fin de poner a dichos países en condiciones de satisfacer la mayor demanda para sus presupuestos.

Otra dificultad reside en que muchos países no cuentan con mecanismos de redes de seguridad establecidos. Es fundamental que tales mecanismos se diseñen por anticipado, incluso cuando en principio no se disponga de fondos suficientes para aplicarlos. Si se ha identificado ya a los grupos vulnerables, en particular las mujeres embarazadas y lactantes y los niños de menos de dos años de edad, se podría activar la red de seguridad, o la reserva alimentaria de emergencia, tan pronto como se presente la crisis, utilizando fondos de la comunidad internacional. Por ejemplo, un componente clave de muchas redes de seguridad, en particular en los programas sociales de transferencias de efectivo, es la entrega de dinero a las mujeres; esto puede aumentar el prestigio de estas dentro de la comunidad y dentro del hogar y traducirse en mejores resultados para los niños desde el punto de vista de la salud y la nutrición. Sin embargo, la eficacia de tales intervenciones depende de que sean cuidadosamente planificadas en lugar de improvisarse a toda prisa cuando llega la crisis. La planificación previa permitirá obtener mejores resultados.

Si las redes de seguridad funcionan mediante el suministro de alimentos (en lugar de efectivo), será necesario contar con 
reservas de emergencia antes de que llegue la ayuda alimentaria, incluidos alimentos especiales para niños de edad comprendida entre seis meses y dos años. Estas reservas deberán estar adecuadamente vinculadas a sistemas eficaces de información y alerta. Deben, además, establecerse en una localización estratégica, buscando el adecuado equilibrio entre una fragmentación excesiva, que entrañaría costos más elevados de seguimiento, el aumento de costos que supondría mantenerlas por completo en zonas con déficit de alimentos y el mayor tiempo de respuesta en caso de que todas las reservas se almacenaran en zonas con excedentes alimentarios. El tamaño de las reservas es otro aspecto que requiere un examen atento. Estas deben bastar, como mínimo, para satisfacer las necesidades de uno o dos meses, dependiendo del tiempo que se requiera para reponer los suministros; como máximo deben ser suficientes para atender a la demanda de alimentos de los grupos vulnerables, pero no para proporcionar subvenciones generales.

Los organismos encargados de las reservas alimentarias deberían aplicar reglas bien definidas y poder actuar con autonomía con respecto al proceso político, de manera análoga a un banco central. Cuando se haga necesario reponer las reservas, el organismo debería adquirir existencias de una manera que no incremente la incertidumbre para los comerciantes privados, en cuyas manos debería estar la mayor parte de la cosecha. Es necesario también que los organismos responsables de las reservas alimentarias colaboren más allá de las fronteras para compartir riesgos más eficazmente.

Un ejemplo prometedor en este sentido es el de la reserva arrocera de emergencia de la Asociación de Naciones del Asia Sudoriental (ASEAN), recientemente ampliada a tres países más.

En aquellos casos en que los países no dispongan de la capacidad necesaria para administrar reservas de emergencia nacionales, se podrían establecer sistemas de reservas alimentarias estratégicas en el ámbito regional. En las regiones expuestas a crisis alimentarias recurrentes y que tienen una infraestructura de transporte débil, tales reservas de emergencia pueden proporcionar alimentos a los hambrientos con rapidez. En 2008, el Programa Mundial de Alimentos (PMA) consiguió suministrar alimentos a beneficiarios de todos los países de la región de África oriental y austral, en forma rápida y eficaz con respecto a los costos, mediante la aplicación de un mecanismo piloto de compras a término en el ámbito regional. Cualquier sistema regional de ese tipo debería sentar las bases para una transición futura a mecanismos de propiedad y control nacionales.

Algunos países que aplicaron restricciones a la exportación en 2008 y 2010 exceptuaron de las mismas las compras de alimentos con fines humanitarios, incluidas las del PMA. Sin embargo, otros no otorgaron tales exenciones, con lo que los organismos humanitarios se vieron obligados a comprar alimentos de fuentes más distantes. En la mayor parte de los casos, cuando se otorga una exención la misma es acordada caso por caso, una vez que se ha planteado la cuestión y se ha solicitado la exención específica. A consecuencia de ello se pierden tiempo y recursos útiles para la respuesta de emergencia, ya que los equipos encargados de las compras deben dedicar tiempo a negociar exenciones o encontrar proveedores alternativos de otras regiones.

Muchos países acordaron comprometerse a exceptuar de las prohibiciones de exportación las compras con fines humanitarios, primero en la Cumbre del G-8 de L'Aquila de julio de 2009 y, sucesivamente, en la Cumbre Mundial sobre la Seguridad Alimentaria celebrada en Roma en noviembre de 2009, en la que todos los Estados Miembros de la FAO acordaron lo siguiente: "Eliminaremos las restricciones a la exportación de alimentos o los impuestos extraordinarios aplicados a los alimentos adquiridos para fines humanitarios no comerciales, mantendremos consultas antes de imponer nuevas restricciones de este tipo y daremos notificación previa de estas". Este compromiso se manifestó asimismo en la Cumbre de Ministros de Agricultura del G-20 celebrada en junio de 2011 (véase el Recuadro 11). Si estos compromisos se cumplen, en las situaciones de emergencia será posible enviar alimentos rápidamente adonde se necesiten.

Mientras que las alzas de precios beneficiarán a los agricultores que dispongan de un excedente para vender, las redes de seguridad para los productores pueden ayudar a proteger los medios de sustento de algunos pequeños campesinos ante el aumento rápido y considerable de los precios internacionales de los fertilizantes y otros insumos. A causa del incremento de los precios de estos insumos, sumado al hecho de que deben adquirirse varios meses antes de la cosecha, es posible que los agricultores se vean obligados a disminuir su uso, lo que podría reducir sus rendimientos y tener un efecto negativo en los medios de vida de los pequeños agricultores.

Los programas de apoyo selectivo destinado a los insumos potencian la capacidad de los pequeños campesinos para responder al incremento de los precios de los alimentos y contribuyen a la seguridad alimentaria familiar y nacional. Por otra parte, las subvenciones específicas para insumos tienen un costo elevado y tales programas son difíciles de administrar, sobre todo en períodos caracterizados por la volatilidad de los precios de alimentos e insumos. Por ejemplo, suele ser muy difícil garantizar la entrega puntual de los fertilizantes a los agricultores. Incluso cuando se logra resolver este problema, las presiones de índole política para expandir los programas de apoyo a los insumos pueden determinar una carga fiscal insostenible, que obstaculiza el crecimiento a largo plazo en lugar de promoverlo. Por consiguiente, es importante que esos programas tengan un carácter temporal y estén dirigidos únicamente a aquellos agricultores que no cuentan con medios para financiar la compra de insumos ${ }^{69}$.

En el plano internacional, muchos países pobres pueden tener dificultades para sufragar los costos más elevados de las importaciones que conllevan las alzas de los precios de los alimentos. Durante la reciente alza de dichos precios, varios países que experimentaban un incremento importante 
El 23 de junio de 2011, los ministros de Agricultura del G-20 se reunieron para abordar la cuestión de la volatilidad de los precios de los alimentos con el objetivo último de mejorar la seguridad alimentaria. Los ministros llegaron a un acuerdo acerca de un "Plan de acción sobre la volatilidad de los precios de los alimentos y la agricultura" que se presentará a los líderes del G-20 en su cumbre de noviembre de 2011. Los debates mantenidos se basaron en el informe interinstitucional sobre la volatilidad de los precios de los alimentos preparado por la FAO, la OCDE, el FIDA, el Fondo Monetario Internacional (FMI), la Conferencia de las Naciones Unidas sobre Comercio y Desarrollo (UNCTAD), el PMA, el Banco Mundial, la Organización Mundial del Comercio (OMC), el IFPRI y el Equipo de tareas de alto nivel de las Naciones Unidas sobre la crisis mundial de la seguridad alimentaria. Los esfuerzos de estas 10 organizaciones internacionales han sido coordinados por la FAO y la OCDE. En el informe se proponía una serie de opciones sobre políticas concretas con el objetivo de reducir la volatilidad y mitigar sus efectos negativos en los países y las poblaciones vulnerables.

En la reunión de ministros de Agricultura del G-20 se aprobaron varias recomendaciones formuladas en el informe interinstitucional. Entre ellas, cabe citar las siguientes:

\section{Producción y productividad agrícolas: los} gobiernos de los países miembros del G-20 se comprometieron a aplicar una amplia gama de medidas para impulsar el crecimiento de la productividad agrícola, aumentar la producción de alimentos y reforzar la sostenibilidad y la capacidad de recuperación del sistema agrícola y alimentario a más largo plazo, prestando especial atención a los pequeños productores, sobre todo las agricultoras y los agricultores jóvenes. Dichas medidas incluirán el fortalecimiento de la investigación y la innovación agrícolas y la creación de un entorno propicio para fomentar la inversión pública y privada en la agricultura.

2. Información y transparencia del mercado: los gobiernos del G-20 crearán el Sistema de información sobre el mercado agrícola (SISMA) para intensificar la colaboración entre las organizaciones internacionales, los principales países exportadores e importadores de alimentos y el sector privado con el objetivo de proporcionar información precisa y transparente. EI SISMA se basará en los mecanismos de información existentes y se ubicará en la FAO.

3. Coordinación de las políticas internacionales: los gobiernos del G-20 pidieron también que se estableciera un Foro de respuesta rápida en el marco del SISMA para mejorar la coordinación internacional de las políticas. En dicho Foro se examinarán respuestas normativas adecuadas cuando la situación del mercado muestre un alto riesgo de inseguridad alimentaria y se trabajará en estrecha colaboración con el Comité de Seguridad Alimentaria Mundial (CFS) para promover una mayor convergencia internacional de las políticas.

4. Reducción de los efectos de la volatilidad de los precios sobre las poblaciones más vulnerables: los ministros de Agricultura del G-20 instaron a los bancos multilaterales de desarrollo y las organizaciones internacionales a elaborar herramientas de gestión del riesgo y ayudar a incorporar globalmente la gestión del riesgo, en particular en lo tocante a los pequeños agricultores, así como a seguir estudiando mecanismos anticíclicos para los países vulnerables en caso de perturbaciones externas, tales como aumentos repentinos de los precios de los alimentos. Los ministros respaldaron también iniciativas encaminadas a incrementar al máximo la eficiencia en la entrega de la ayuda alimentaria y a fortalecer las cadenas de suministro frente a las crisis de los precios y de la oferta, en concreto por conducto de redes ubicadas en primera línea y de la incorporación global de la gestión del riesgo en las actividades de compra en relación con la ayuda alimentaria internacional. En el G-20 se acordó asimismo eliminar las restricciones a la exportación y los impuestos extraordinarios aplicados a los alimentos adquiridos por el PMA para fines humanitarios no comerciales y se convino no imponer dichas medidas en el futuro.

5. Regulación financiera: los ministros de Agricultura del G-20 alentaron firmemente a los ministros de Finanzas del G-20 a que tomaran las decisiones apropiadas para mejorar la regulación y la supervisión de los mercados de futuros y derivados agrícolas. 
del costo de sus importaciones de alimentos y fertilizantes recurrieron al Servicio para Shocks Exógenos (SSE) del Fondo Monetario Internacional. El SSE proporciona liquidez para reducir los efectos negativos de las crisis exógenas en las balanzas de pago de los países en desarrollo, la situación de las reservas internacionales y la inflación. Tal mecanismo podría ampliarse a fin de poner a un país en condiciones de financiar sus importaciones de alimentos cuando surja tal necesidad, en lugar de compensar después las pérdidas en la balanza de pagos. Se debería brindar respaldo a mecanismos tales como el Programa de respuesta a la crisis mundial de los alimentos, del Banco Mundial, que está destinado a los países más pobres y más vulnerables, y a los esfuerzos por ampliar la atención prestada a las situaciones de crisis en el marco de la Asociación Internacional de Fomento.

10000000000000000000000000000000000000000

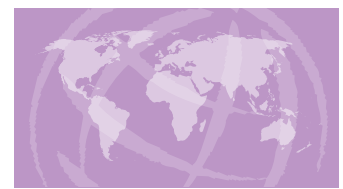

\section{Cómo prevenir la volatilidad de los precios a largo plazo: incremento de la productividad, la sostenibilidad y la capacidad de resistencia de la agricultura}

\section{Mensaje principal}

La inversión en la agricultura mejorará la competitividad de la producción interna, incrementará las ganancias de los agricultores y hará que los alimentos sean más asequibles para los pobres. Aunque la mayor parte de esta inversión corresponderá al sector privado, la inversión pública debe cumplir una función catalizadora al proporcionar bienes públicos que el sector privado no suministraría. Estas inversiones deberían tomar en cuenta los derechos de los actuales usuarios de las tierras y los recursos naturales conexos, beneficiar a las comunidades locales, promover la seguridad alimentaria, y no deberían causar daño indebido al medio ambiente.

En las próximas cuatro décadas el sector agrícola mundial se enfrentará con retos importantes. El continuo incremento demográfico impulsará la demanda de alimentos a la vez que el cambio climático y la degradación de los recursos naturales supondrán dificultades para el suministro, tanto en lo que atañe a la producción promedio como a la volatilidad de la producción. Cálculos de la FAO indican que la producción agrícola mundial deberá crecer en un 70 \% entre 2005-07 y 2050, y casi en un $100 \%$ en los países en desarrollo, para poder alimentar a una población de más de 9000 millones de personas en 2050. Un incremento productivo insuficiente hará que los precios sean más altos y más volátiles.

Es importante observar que incrementar la producción en las fincas no es la única forma de aumentar los suministros y satisfacer la demanda. La FAO estimó hace poco que cada año se pierden o desperdician 1300 millones de toneladas de alimentos. La mayor parte del desperdicio se produce en los países desarrollados, y la mayoría de las pérdidas en los países en desarrollo. El desafío consiste en encontrar formas eficaces con respecto a los costos de reducir ese desperdicio y esas pérdidas. Así pues, la investigación y la inversión en la mejora de la gestión y la logística después de la cosecha será un componente importante de la estrategia más general de desarrollo agrícola.

La inversión destinada a crear un sector agrícola más productivo y eficiente permitirá que los alimentos sean más asequibles para los pobres, y también reducirá la volatilidad de los precios. Existe, además, una clara demanda de este tipo de inversiones por parte de la propia población rural pobre. De acuerdo con sondeos Gallup la población del África subsahariana considera que la agricultura es la cuestión más importante de la que deben ocuparse sus gobiernos, y que la reducción de la pobreza y el hambre son los dos Objetivos de Desarrollo del Milenio más importantes ${ }^{70}$. Una mayor inversión se traducirá en un desarrollo más rápido de la agricultura, el cual, según se ha demostrado, tiene un efecto positivo mayor en los ingresos de la población pobre que el crecimiento fuera del sector

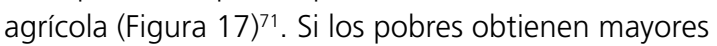
ingresos, sus hogares serán menos vulnerables a crisis económicas como las determinadas por las fluctuaciones de los precios y será menor el peligro de que caigan en las trampas de la pobreza.

Existen señales alentadoras de que quizás estén empezando a crecer las existencias de capital agrícola 


\section{FIGURA 17}

El impacto en los ingresos de los pobres de un incremento del crecimiento agrícola es más fuerte y positivo que el de un incremento equivalente del crecimiento no agrícola

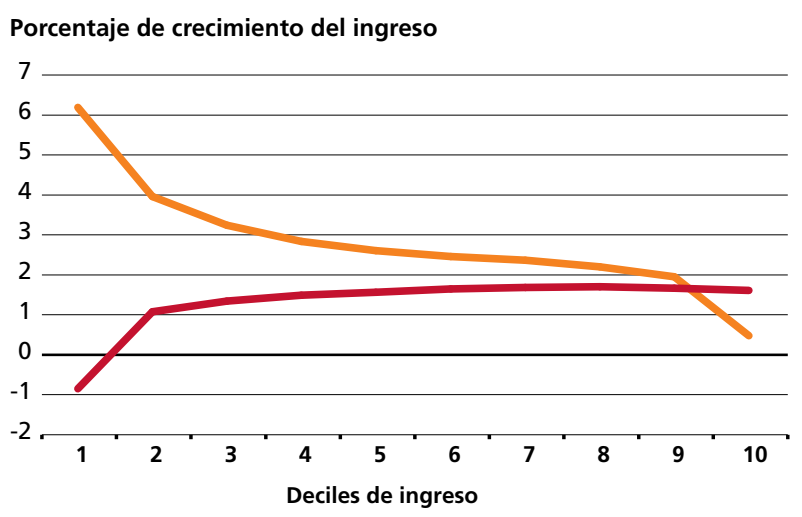

- Crecimiento agrícola -Crecimiento no agrícola

Nota: El decil de ingresos 1 se refiere al $10 \%$ más pobre de la población, y aś sucesivamente. El gasto es usado como variable sustitutiva del ingreso, como suele hacerse en el análisis de los datos de encuestas de hogares.

Fuente: E. Ligon y E. Sadoulet. 2007. Estimating the effects of aggregate agricultural growth Fuente: E. Ligon y E. Sadoulet. 2007. Estimating the effects of aggregate agricultural growth
on the distribution of expenditures. Documento de antecedentes para el Informe sobre el desarrollo mundial 2008 (disponible en inglés en la dirección

http://siteresources. worldbank.org/INTWDR2008/Resources/2795087-1191427986785/ LigonE\&SadouletE_EstimatingEffectsOfAggAgGr.pdf).

(como edificios, equipos y ganado). El nivel del capital agrícola por trabajador se mantuvo en gran parte estancado en los países de ingresos medios y bajos desde mediados de la década de 1980 hasta principios de la de 2000, pero se incrementó en 2004 y 2005 que son los años más recientes sobre los que se dispone de datos ${ }^{72}$. Es necesario que estos incrementos se mantengan durante largos períodos: para duplicar la producción agrícola de los países en desarrollo se requerirá una inversión bruta anual promedio de 209000 millones de USD (en dólares estadounidenses de 2009), aproximadamente un $50 \%$ anual más elevada que la actual ${ }^{73}$. Este total comprende las inversiones necesarias en la agricultura primaria y en servicios posteriores a la cosecha, como el almacenamiento y la elaboración, pero no incluye bienes públicos como las carreteras o los proyectos de riego y electrificación en gran escala que también se requieren. El aporte de inversiones de esta envergadura representa un reto formidable, al que sin embargo es preciso responder para que sea posible eliminar el hambre del mundo.

La mayor parte de la inversión, tanto en la agricultura primaria como en los servicios posteriores a la cosecha, deberá proceder de fuentes privadas. Los propios agricultores deben adquirir herramientas y maquinaria, hacer inversiones para mejorar la fertilidad del suelo y adquirir conocimientos con miras a una gestión más eficiente de sus fincas. También es necesario estimular la inversión del sector privado en todas las etapas de la cadena de valor: antes del cultivo, en la producción y distribución de semillas y fertilizantes y, después de la cosecha, en la elaboración, comercialización y distribución de los productos.

Los agricultores y futuros agricultores invertirán en la agricultura únicamente si sus inversiones son rentables, pero para esto se requiere un entorno normativo reglamentario apropiado y se necesitan inversiones en una vasta gama de bienes públicos. Es indispensable contar con tres tipos de inversión pública:

- inversiones directas en investigación y desarrollo sobre agricultura con objeto de aumentar la productividad y potenciar la capacidad de los sistemas agrícolas, especialmente las pequeñas fincas, para hacer frente al cambio climático y a la escasez de recursos;

- inversiones dirigidas a establecer un vínculo entre el sector agrícola primario y las fuentes de demanda, lo que comprende las instituciones agrícolas, los servicios de extensión, los caminos rurales, los puertos, la energía y los sistemas de almacenamiento y de riego;

- inversiones no agrícolas destinadas a potenciar el entorno institucional de las zonas rurales y mejorar el bienestar humano; estas inversiones comprenden la educación (especialmente de las mujeres), el saneamiento, el abastecimiento de agua pura y la atención médica.

Todas estas inversiones han mostrado tener índices de rendimiento muy elevados, tanto desde el punto de vista financiero como de la reducción de la pobreza ${ }^{74}$. Las inversiones dirigidas a incrementar la productividad y la resistencia de la agricultura de los países en desarrollo pueden contribuir de muchas formas a mejorar la seguridad alimentaria. Están en condiciones de reducir la volatilidad de los precios gracias al aumento de la productividad y a una gestión técnica más adecuada de la producción y del riesgo, especialmente frente al cambio climático. Pueden ayudar a los agricultores y las familias a defenderse mejor de los efectos de la volatilidad cuando esta se produce. Pueden, además, hacer que los alimentos resulten más asequibles para los consumidores pobres, e incrementar los ingresos de los agricultores de pocos recursos. Este tipo de inversión será más eficaz para reducir la pobreza si es apropiada para los agricultores en pequeña escala, a los que corresponderá una parte considerable de la producción de los países en desarrollo en el futuro previsible.

Gran parte de la investigación que realiza el sector público la llevan a cabo los centros internacionales de investigación del Grupo Consultivo sobre Investigación Agrícola Internacional (GCIAI), aunque actualmente instituciones de investigación pública de países como el Brasil, China y la India aportan una proporción cada vez mayor de bienes públicos en la esfera de la investigación agrícola. Se ha establecido un nuevo fondo fiduciario de donantes múltiples, el Fondo del GCIAI (que hospeda y administra el Banco Mundial), a fin de armonizar las inversiones de los donantes para hacer frente a los retos 
mundiales relacionados con la agricultura. Los nuevos programas de investigación orientados a los resultados se centrarán en políticas y tecnologías dirigidas a la mitigación del cambio climático y adaptación a sus efectos; estos programas abarcan a un amplio grupo de asociados. Se hace necesario incrementar y sostener la financiación de tales órganos a fin de que puedan seguir invirtiendo ahora en las técnicas e innovaciones necesarias para hacer frente a los desafíos futuros de la seguridad alimentaria y el cambio climático.

El incremento de la inversión pública en transporte e infraestructura productiva, así como en el capital humano, también es fundamental para estimular la productividad y reducir el desperdicio después de la cosecha. Las mejoras de la infraestructura, en particular caminos rurales, sistemas de riego e instalaciones relacionadas con la comercialización tales como depósitos, sistemas de almacenamiento refrigerado y mecanismos de información sobre los mercados, harán disminuir los costos del transporte, permitirán integrar a los pequeños agricultores en los mercados y reducirán la volatilidad de los precios. Las mejoras de la extensión, la educación y la atención médica son otros elementos esenciales de un planteamiento sólido en materia de políticas para incrementar la productividad y potenciar la seguridad alimentaria y el bienestar de los agricultores y los consumidores.

Estos tipos de inversión en capital humano, infraestructura y conocimientos científicos son bastante elementales, pero resultan indispensables a fin de que los pobres puedan elevarse por encima de la pobreza. Es difícil imaginar que sea posible erradicar la inseguridad alimentaria sin tales inversiones. Hemos logrado progresos en la reducción de la pobreza y la inseguridad alimentaria; podemos hacer incluso más si nos basamos en análisis fiables, en buenos conocimientos científicos y en una financiación suficiente para llevar a cabo intervenciones apropiadas. Para esto se necesitará el compromiso de toda la comunidad internacional a fin de resaltar mejor el papel de la agricultura, no solamente el año que viene o dentro de dos años sino, en última instancia, hasta que todas las personas puedan disponer en todo momento de acceso físico, social y económico a alimentos suficientes, seguros y nutritivos, acordes a sus necesidades dietéticas y sus preferencias alimentarias, para poder llevar una vida activa y sana. 
CUADRO ANEXO

Prevalencia de la subnutrición y progreso hacia la consecución del objetivo de la Cumbre Mundial sobre la Alimentación (CMA) y la meta del primer Objetivo de Desarrollo del Milenio (ODM) ${ }^{2}$ en los países en desarrollo 3

\begin{tabular}{|c|c|c|c|c|c|c|c|c|c|c|c|c|c|}
\hline \multirow{4}{*}{$\begin{array}{l}\text { MUNDO } \\
\text { Región/subregión/país } \\
\text { MUNDO }\end{array}$} & \multirow{4}{*}{$\begin{array}{c}\begin{array}{c}\text { Población } \\
\text { total }\end{array} \\
2006-08 \\
\text { (millones) } \\
6652,5\end{array}$} & \multicolumn{6}{|c|}{ Número de personas subnutridas } & \multicolumn{6}{|c|}{$\begin{array}{l}\text { Proporción de personas subnutridas en relación con la } \\
\text { población total }\end{array}$} \\
\hline & & $1990-92$ & 1995-97 & $2000-02$ & $2006-08$ & $\begin{array}{c}\text { Variación } \\
\text { hasta la } \\
\text { fecha }\end{array}$ & \multirow{2}{*}{$\begin{array}{c}\text { Progreso } \\
\text { hacia el } \\
\text { objetivo } \\
\text { de la CMA }\end{array}$} & 1990-92 & 1995-97 & $2000-02$ & 2006-08 & $\begin{array}{c}\text { Variación } \\
\text { hasta la } \\
\text { fecha } \\
\end{array}$ & \multirow{2}{*}{$\begin{array}{l}\text { Progreso } \\
\text { hacia la } \\
\text { meta del } \\
\mathrm{ODM}^{4}\end{array}$} \\
\hline & & \multicolumn{4}{|c|}{ (millones) } & $(\%)$ & & \multicolumn{4}{|c|}{ (\%) } & $(\%)$ & \\
\hline & & 848,4 & 791,5 & 836,2 & 850,0 & 0,2 & & 16 & 14 & 14 & 13 & -19 & \\
\hline Regiones desarrolladas & 1231,3 & 15,3 & 17,5 & 15,4 & 10,6 & $-30,8$ & & - & - & - & - & n.d. & \\
\hline Regiones en desarrollo & 5420,2 & 833,2 & 774,0 & 820,8 & 839,4 & 0,8 & & 20 & 17 & 17 & 15 & -22 & \\
\hline Países menos adelantados 5 & 796,7 & 211,2 & 249,4 & 244,7 & 263,8 & 24,9 & & 39 & 41 & 35 & 33 & -16 & \\
\hline Países en desarrollo sin litoral ${ }^{6}$ & 382,8 & 90,2 & 101,6 & 102,5 & 98,3 & 8,9 & & 34 & 34 & 31 & 26 & -24 & \\
\hline $\begin{array}{l}\text { Pequeños Estados insulares en } \\
\text { desarrollo }\end{array}$ & 52,2 & 9,6 & 10,9 & 9,7 & 10,7 & 11,8 & & 23 & 24 & 20 & 21 & -10 & \\
\hline ÁFRICA & 962,9 & 170,9 & 193,6 & 203,3 & 223,6 & 30,8 & & 26 & 26 & 24 & 23 & -11 & \\
\hline África septentrional & 161,4 & 5,0 & 5,4 & 5,6 & 6,1 & 23,4 & & - & - & - & - & n.d. & \\
\hline Argelia & 33,9 & n.s. & 1,5 & 1,4 & n.s. & n.d. & & - & 5 & 5 & - & n.d. & H \\
\hline Egipto & 80,1 & n.s. & n.s. & n.s. & n.s. & n.d. & & - & - & - & - & n.d. & \\
\hline Jamahiriya Árabe Libia & 6,2 & n.s. & n.s. & n.s. & n.s. & n.d. & & - & - & - & - & n.d. & \\
\hline Marruecos & 31,2 & 1,5 & 1,6 & 1,6 & n.s. & n.d. & & 6 & 6 & 6 & - & n.d. & \\
\hline Túnez & 10,1 & n.s. & n.s. & n.s. & n.s. & n.d. & & - & - & - & - & n.d. & 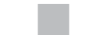 \\
\hline África subsahariana ${ }^{8}$ & 801,5 & 165,9 & 188,2 & 197,7 & 217,5 & 31,1 & & 31 & 31 & 29 & 27 & -13 & . \\
\hline Angola & 17,6 & 7,4 & 7,8 & 7,6 & 7,2 & $-2,4$ & & 67 & 61 & 52 & 41 & -39 & 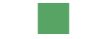 \\
\hline Benin & 8,4 & 1,0 & 1,0 & 1,0 & 1,0 & $-0,3$ & & 20 & 18 & 15 & 12 & -41 & \\
\hline Botswana & 1,9 & 0,3 & 0,4 & 0,5 & 0,5 & 85,4 & & 19 & 23 & 27 & 25 & 36 & 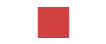 \\
\hline Burkina Faso & 14,7 & 1,2 & 1,2 & 1,4 & 1,2 & $-3,0$ & & 14 & 12 & 12 & 8 & -40 & 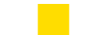 \\
\hline Burundi & 7,8 & 2,5 & 3,5 & 3,9 & 4,9 & 93,8 & & 44 & 56 & 59 & 62 & 43 &  \\
\hline Camerún & 18,7 & 4,2 & 5,0 & 4,3 & 4,2 & $-0,5$ & & 33 & 34 & 26 & 22 & -33 & \\
\hline Chad & 10,6 & 3,8 & 3,9 & 3,7 & 4,1 & 8,3 & & 60 & 53 & 43 & 39 & -36 & \\
\hline Congo & 3,6 & 1,0 & 1,2 & 0,6 & 0,5 & $-55,4$ & & 42 & 41 & 20 & 13 & -68 & \\
\hline Côte d'Ivoire & 20,1 & 1,9 & 2,6 & 2,9 & 2,9 & 50,9 & & 15 & 17 & 17 & 14 & -2 & . \\
\hline Eritrea & 4,8 & 2,1 & 2,1 & 2,7 & 3,1 & 44,9 & & 67 & 64 & 70 & 65 & -4 & 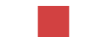 \\
\hline Etiopía & 78,7 & 34,7 & 36,2 & 32,6 & 32,6 & $-6,1$ & & 69 & 62 & 48 & 41 & -40 & \\
\hline Gabón & 1,4 & 0,1 & n.s. & n.s. & n.s. & n.d. & & 6 & - & - & - & n.d. & \\
\hline Gambia & 1,6 & 0,1 & 0,3 & 0,3 & 0,3 & 143,9 & & 14 & 23 & 21 & 19 & 41 & \\
\hline Ghana & 22,9 & 4,3 & 2,3 & 1,9 & 1,1 & $-74,0$ & & 28 & 13 & 9 & 5 & -83 & 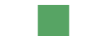 \\
\hline Guinea & 9,6 & 1,3 & 1,5 & 1,7 & 1,6 & 23,5 & 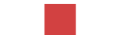 & 20 & 19 & 20 & 16 & -18 & 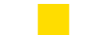 \\
\hline Kenya & 37,8 & 8,1 & 9,0 & 10,6 & 12,4 & 54,1 & & 33 & 32 & 33 & 33 & -1 & $\square$ \\
\hline
\end{tabular}


CUADRO ANEXO

Prevalencia de la subnutrición y progreso hacia la consecución del objetivo de la Cumbre Mundial sobre la Alimentación $(\mathrm{CMA})^{1}$ y la meta del primer Objetivo de Desarrollo del Milenio (ODM) ${ }^{2}$ en los países en desarrollo ${ }^{3}$

\begin{tabular}{|c|c|c|c|c|c|c|c|c|c|c|c|c|c|}
\hline \multirow[t]{3}{*}{$\begin{array}{l}\text { MUNDO } \\
\text { Región/subregión/país }\end{array}$} & \multirow{2}{*}{$\begin{array}{c}\begin{array}{c}\text { Población } \\
\text { total }\end{array} \\
2006-08\end{array}$} & \multicolumn{6}{|c|}{ Número de personas subnutridas } & \multicolumn{6}{|c|}{$\begin{array}{l}\text { Proporción de personas subnutridas en relación con la } \\
\text { población total }\end{array}$} \\
\hline & & $1990-92$ & 1995-97 & $2000-02$ & 2006-08 & $\begin{array}{c}\text { Variación } \\
\text { hasta la } \\
\text { fecha }\end{array}$ & $\begin{array}{l}\text { Progreso } \\
\text { hacia el } \\
\text { objetivo }\end{array}$ & 1990-92 & 1995-97 & $2000-02$ & $2006-08$ & $\begin{array}{c}\text { Variación } \\
\text { hasta la } \\
\text { fecha }\end{array}$ & $\begin{array}{c}\text { Progreso } \\
\text { hacia la } \\
\text { meta del }\end{array}$ \\
\hline & (millones) & \multicolumn{4}{|c|}{ (millones) } & $(\%)$ & de la CIVIA & \multicolumn{4}{|c|}{ (\%) } & $(\%)$ & ODIV" \\
\hline Lesotho & 2,0 & 0,2 & 0,3 & 0,3 & 0,3 & 15,6 & & 15 & 16 & 14 & 14 & -7 & \\
\hline Liberia & 3,6 & 0,6 & 0,7 & 1,1 & 1,1 & 85,0 & & 30 & 32 & 36 & 32 & 7 & \\
\hline Madagascar & 18,6 & 2,4 & 3,5 & 4,4 & 4,7 & 98,7 & & 21 & 26 & 28 & 25 & 24 & \\
\hline Malawi & 14,4 & 4,2 & 3,8 & 3,6 & 3,9 & $-5,9$ & & 43 & 36 & 30 & 27 & -37 & \\
\hline Malí & 12,4 & 2,4 & 2,5 & 1,9 & 1,5 & $-38,1$ & & 27 & 25 & 18 & 12 & -56 & \\
\hline Mauricio & 1,3 & 0,1 & 0,1 & 0,1 & 0,1 & $-17,2$ & & 7 & 7 & 5 & 5 & -30 & \\
\hline Mauritania & 3,1 & 0,2 & 0,2 & 0,2 & 0,2 & 1,9 & & 12 & 9 & 8 & 8 & -34 & \\
\hline Mozambique & 21,9 & 8,2 & 7,8 & 8,5 & 8,3 & 0,8 & & 59 & 47 & 46 & 38 & -36 & \\
\hline Namibia & 2,1 & 0,5 & 0,5 & 0,4 & 0,4 & $-18,5$ & & 32 & 30 & 21 & 18 & -43 & 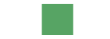 \\
\hline Níger & 14,1 & 3,0 & 3,5 & 3,1 & 2,3 & $-22,2$ & & 37 & 37 & 27 & 16 & -55 & \\
\hline Nigeria & 147,7 & 16,3 & 10,9 & 11,9 & 9,4 & $-42,3$ & & 16 & 10 & 9 & 6 & -61 & \\
\hline República Centroafricana & 4,3 & 1,3 & 1,6 & 1,6 & 1,7 & 30,2 & & 44 & 47 & 43 & 40 & -8 & \\
\hline República Unida de Tanzanía & 41,3 & 7,7 & 12,8 & 14,0 & 13,9 & 79,9 & & 29 & 42 & 40 & 34 & 15 & \\
\hline Rwanda & 9,5 & 3,0 & 3,0 & 3,1 & 3,0 & 0,3 & & 44 & 53 & 38 & 32 & -28 & \\
\hline Senegal & 11,9 & 1,7 & 2,3 & 2,6 & 2,3 & 32,4 & & 22 & 26 & 26 & 19 & -14 & \\
\hline Sierra Leona & 5,4 & 1,8 & 1,6 & 1,9 & 1,9 & 3,6 & & 45 & 39 & 43 & 35 & -22 & \\
\hline Sudáfrica & 49,2 & n.s. & n.s. & n.s. & n.s. & n.d. & & - & - & - & - & n.d. & \\
\hline Sudán & 40,4 & 10,8 & 9,3 & 9,8 & 8,8 & $-17,9$ & & 39 & 29 & 28 & 22 & -44 & 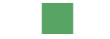 \\
\hline Swazilandia & 1,2 & 0,1 & 0,2 & 0,2 & 0,2 & 110,9 & & 12 & 21 & 18 & 19 & 63 & \\
\hline Togo & 6,3 & 1,7 & 1,7 & 1,9 & 1,9 & 7,6 & & 43 & 36 & 36 & 30 & -31 & \\
\hline Uganda & 30,6 & 3,5 & 4,9 & 4,8 & 6,7 & 92,5 & & 19 & 23 & 19 & 22 & 15 & \\
\hline Zambia & 12,3 & 2,9 & 3,6 & 4,7 & 5,4 & 86,5 & & 35 & 38 & 43 & 44 & 23 & \\
\hline Zimbabwe & 12,5 & 4,3 & 5,3 & 5,1 & 3,7 & $-14,1$ & & 40 & 44 & 41 & 30 & -26 & \\
\hline AMÉRICA LATINA Y EL CARIBE & 564,3 & 54,4 & 53,4 & 50,8 & 47,0 & $-13,7$ & & 12 & 11 & 10 & 8 & -32 & \\
\hline América Latina $^{9}$ & 528,2 & 46,7 & 44,5 & 43,4 & 38,6 & $-17,2$ & & 11 & 10 & 9 & 7 & -35 & \\
\hline Argentina & 39,5 & n.s. & n.s. & n.s. & n.s. & n.d. & 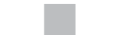 & - & - & - & - & n.d. & \\
\hline Bolivia (Estado Plurinacional de) & 9,5 & 2,0 & 1,9 & 1,9 & 2,5 & 29,7 & & 29 & 24 & 22 & 27 & -7 & \\
\hline Brasil & 190,1 & 17,1 & 16,6 & 16,2 & 11,7 & $-31,5$ & & 11 & 10 & 9 & 6 & -45 & \\
\hline Chile & 16,6 & 0,9 & n.s. & n.s. & n.s. & n.d. & & 7 & - & - & - & n.d. & \\
\hline Colombia & 44,4 & 5,2 & 4,0 & 3,9 & 4,1 & $-20,7$ & 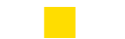 & 15 & 11 & 10 & 9 & -40 & \\
\hline Costa Rica & 4,5 & n.s. & n.s. & n.s. & n.s. & n.d. & & - & - & - & - & n.d. & \\
\hline
\end{tabular}


CUADRO ANEXO

Prevalencia de la subnutrición y progreso hacia la consecución del objetivo de la Cumbre Mundial sobre la Alimentación (CMA) ${ }^{1}$ y la meta del primer Objetivo de Desarrollo del Milenio (ODM) ${ }^{2}$ en los países en desarrollo 3

\begin{tabular}{|c|c|c|c|c|c|c|c|c|c|c|c|c|c|}
\hline \multirow[t]{3}{*}{$\begin{array}{l}\text { MUNDO } \\
\text { Región/subregión/país }\end{array}$} & \multirow{3}{*}{$\begin{array}{c}\begin{array}{c}\text { Población } \\
\text { total }\end{array} \\
2006-08\end{array}$} & \multicolumn{6}{|c|}{ Número de personas subnutridas } & \multicolumn{6}{|c|}{$\begin{array}{l}\text { Proporción de personas subnutridas en relación con la } \\
\text { población total }\end{array}$} \\
\hline & & 1990-92 & 1995-97 & $2000-02$ & $2006-08$ & $\begin{array}{c}\text { Variación } \\
\text { hasta la } \\
\text { fecha }\end{array}$ & $\begin{array}{l}\text { Progreso } \\
\text { hacia el } \\
\text { objetivo }\end{array}$ & $1990-92$ & 1995-97 & $2000-02$ & $2006-08$ & $\begin{array}{c}\text { Variación } \\
\text { hasta la } \\
\text { fecha }\end{array}$ & $\begin{array}{c}\text { Progreso } \\
\text { hacia la } \\
\text { meta del }\end{array}$ \\
\hline & & \multicolumn{4}{|c|}{ (millones) } & (\%) & MA $^{4}$ & \multicolumn{4}{|c|}{ (\%) } & (\%) & \\
\hline Ecuador & 13,3 & 2,4 & 1,8 & 2,1 & 2,0 & $-16,1$ & & 23 & 16 & 17 & 15 & -34 & \\
\hline El Salvador & 6,1 & 0,7 & 0,7 & 0,4 & 0,6 & $-17,6$ & & 13 & 12 & 7 & 9 & -27 & \\
\hline Guatemala & 13,4 & 1,4 & 2,1 & 2,5 & 2,9 & 113,4 & & 15 & 20 & 22 & 22 & 46 & \\
\hline Guyana & 0,8 & 0,2 & 0,1 & 0,1 & 0,1 & $-60,6$ & & 20 & 11 & 7 & 8 & -61 & \\
\hline Honduras & 7,2 & 1,0 & 0,9 & 0,9 & 0,9 & $-10,6$ & & 19 & 16 & 14 & 12 & -37 & \\
\hline México & 107,5 & n.s. & n.s. & n.s. & n.s. & n.d. & & - & - & - & - & n.d. & \\
\hline Nicaragua & 5,6 & 2,1 & 1,8 & 1,3 & 1,1 & $-50,4$ & & 50 & 38 & 25 & 19 & -62 & \\
\hline Panamá & 3,3 & 0,5 & 0,6 & 0,6 & 0,5 & 10,4 & & 18 & 20 & 19 & 15 & -19 & \\
\hline Paraguay & 6,1 & 0,7 & 0,5 & 0,5 & 0,6 & $-11,3$ & & 16 & 10 & 10 & 10 & -37 & \\
\hline Perú & 28,5 & 6,1 & 5,0 & 4,7 & 4,5 & $-26,1$ & & 27 & 21 & 18 & 16 & -42 & \\
\hline Suriname & 0,5 & 0,1 & 0,1 & 0,1 & 0,1 & 27,9 & & 14 & 13 & 15 & 15 & 3 & \\
\hline Uruguay & 3,3 & 0,2 & n.s. & n.s. & n.s. & n.d. & & 5 & - & - & - & n.d. & \\
\hline Venezuela (Rep. Bolivariana de) & 27,7 & 2,1 & 3,1 & 3,3 & 1,9 & $-6,5$ & & 10 & 14 & 13 & 7 & -32 & \\
\hline Caribe $^{10}$ & 36,1 & 7,7 & 8,9 & 7,4 & 8,3 & 7,6 & & 25 & 28 & 22 & 23 & -10 & \\
\hline Cuba & 11,2 & 0,6 & 1,5 & n.s. & n.s. & n.d. & 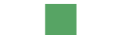 & 6 & 14 & - & - & n.d. & \\
\hline Haití & 9,7 & 4,6 & 4,8 & 4,7 & 5,5 & 21,7 & & 63 & 60 & 53 & 57 & -9 & \\
\hline Jamaica & 2,7 & 0,3 & 0,2 & 0,1 & 0,1 & $-52,3$ & & 11 & 6 & 5 & 5 & -58 & \\
\hline República Dominicana & 9,8 & 2,1 & 2,1 & 2,2 & 2,3 & 11,7 & & 28 & 26 & 25 & 24 & -14 & \\
\hline Trinidad y Tabago & 1,3 & 0,1 & 0,2 & 0,1 & 0,2 & 14,2 & & 11 & 14 & 11 & 11 & 6 & \\
\hline
\end{tabular}

\begin{tabular}{|c|c|c|c|c|c|c|c|c|c|c|c|}
\hline ASIA & 3884,3 & 607,1 & 526,2 & 565,7 & 567,8 & $-6,5$ & 20 & 16 & 16 & 15 & -27 \\
\hline Asia meridional ${ }^{11}$ & 1642,8 & 267,5 & 269,0 & 307,9 & 330,1 & 23,4 & 22 & 20 & 21 & 20 & -8 \\
\hline Bangladesh & 157,7 & 44,4 & 54,2 & 42,3 & 41,4 & $-6,8$ & 38 & 41 & 30 & 26 & -30 \\
\hline India & 1164,6 & 177,0 & 167,1 & 208,0 & 224,6 & 26,9 & 20 & 17 & 20 & 19 & -4 \\
\hline Irán (República Islámica del) & 72,4 & n.s. & n.s. & n.s. & n.s. & n.d. & - & - & - & - & n.d. \\
\hline Nepal & 28,3 & 4,2 & 4,4 & 4,6 & 4,7 & 13,3 & 21 & 20 & 18 & 17 & -22 \\
\hline Pakistán & 173,2 & 29,5 & 26,8 & 36,3 & 42,8 & 45,0 & 25 & 20 & 24 & 25 & -1 \\
\hline Sri Lanka & 19,9 & 4,8 & 4,5 & 3,9 & 3,9 & $-18,4$ & 28 & 25 & 20 & 20 & -28 \\
\hline Asia meridional - excepto la India & 478,1 & 90,5 & 101,9 & 99,9 & 105,5 & 16,7 & 26 & 26 & 23 & 22 & -16 \\
\hline Asia occidental ${ }^{12}$ & 191,3 & 7,4 & 12,5 & 13,9 & 14,2 & 93,0 & 6 & 8 & 8 & 7 & 32 \\
\hline Arabia Saudita & 24,7 & n.s. & n.s. & n.s. & n.s. & n.d. & - & - & - & - & n.d. \\
\hline
\end{tabular}


CUADRO ANEXO

Prevalencia de la subnutrición y progreso hacia la consecución del objetivo de la Cumbre Mundial sobre la Alimentación $(\mathrm{CMA})^{1}$ y la meta del primer Objetivo de Desarrollo del Milenio (ODM) ${ }^{2}$ en los países en desarrollo ${ }^{3}$

\begin{tabular}{|c|c|c|c|c|c|c|c|c|c|c|c|c|c|}
\hline \multirow[t]{3}{*}{$\begin{array}{l}\text { MUNDO } \\
\text { Región/subregión/país }\end{array}$} & \multirow{2}{*}{$\begin{array}{c}\begin{array}{c}\text { Población } \\
\text { total }\end{array} \\
2006-08\end{array}$} & \multicolumn{6}{|c|}{ Número de personas subnutridas } & \multicolumn{6}{|c|}{$\begin{array}{l}\text { Proporción de personas subnutridas en relación con la } \\
\text { población total }\end{array}$} \\
\hline & & 1990-92 & 1995-97 & $2000-02$ & 2006-08 & $\begin{array}{c}\text { Variación } \\
\text { hasta la } \\
\text { fecha }\end{array}$ & $\begin{array}{l}\text { Progreso } \\
\text { hacia el } \\
\text { objetivo }\end{array}$ & 1990-92 & 1995-97 & $2000-02$ & $2006-08$ & $\begin{array}{c}\text { Variación } \\
\text { hasta la } \\
\text { fecha }\end{array}$ & $\begin{array}{c}\text { Progreso } \\
\text { hacia la } \\
\text { meta del }\end{array}$ \\
\hline & (millones) & \multicolumn{4}{|c|}{ (millones) } & $(\%)$ & de la CMA & \multicolumn{4}{|c|}{ (\%) } & $(\%)$ & $\mathrm{ODM}^{4}$ \\
\hline Emiratos Árabes Unidos & 4,4 & n.s. & n.s. & n.s. & n.s. & n.d. & 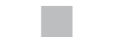 & - & - & - & - & n.d. & \\
\hline Jordania & 5,9 & n.s. & 0,2 & 0,2 & n.s. & n.d. & 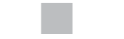 & - & 5 & 5 & - & n.d. & \\
\hline Kuwait & 2,8 & 0,4 & 0,1 & 0,1 & 0,1 & $-65,7$ & & 20 & 5 & 6 & 5 & -75 & \\
\hline Líbano & 4,2 & n.s. & n.s. & n.s. & n.s. & n.d. & & - & - & - & - & n.d. & \\
\hline República Árabe Siria & 20,5 & n.s. & n.s. & n.s. & n.s. & n.d. & 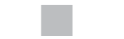 & - & - & - & - & n.d. & \\
\hline Turquía & 73,0 & n.s. & n.s. & n.s. & n.s. & n.d. & 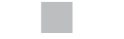 & - & - & - & - & n.d. & \\
\hline Yemen & 22,3 & 3,8 & 5,0 & 5,7 & 6,7 & 75,3 & 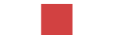 & 30 & 31 & 31 & 30 & 2 & \\
\hline Asia oriental & 1410,8 & 215,6 & 149,5 & 141,8 & 139,4 & $-35,3$ & & 18 & 12 & 10 & 10 & -44 & \\
\hline China & 1336,5 & 210,0 & 141,7 & 132,8 & 129,6 & $-38,3$ & & 18 & 12 & 10 & 10 & -46 & \\
\hline Mongolia & 2,6 & 0,6 & 0,8 & 0,6 & 0,7 & 11,4 & & 28 & 33 & 27 & 27 & -5 & \\
\hline República de Corea & 48,0 & n.s. & n.s. & n.s. & n.s. & n.d. & t & - & - & - & - & n.d. & \\
\hline Rep. Dem. Pop. de Corea & 23,7 & 4,2 & 6,6 & 7,8 & 8,4 & 99,6 & 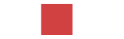 & 21 & 30 & 34 & 35 & 72 & \\
\hline Asia oriental - excepto China & 74,3 & 5,5 & 7,9 & 9,0 & 9,8 & 77,1 & & 8 & 11 & 13 & 13 & 57 & \\
\hline Asia sudoriental ${ }^{13}$ & 564,0 & 105,8 & 86,0 & 89,6 & 77,4 & $-26,9$ & & 24 & 18 & 17 & 14 & -42 & \\
\hline Camboya & 14,3 & 3,8 & 4,7 & 3,8 & 3,6 & $-4,5$ & 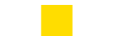 & 38 & 40 & 29 & 25 & -33 & \\
\hline Filipinas & 88,7 & 15,3 & 14,1 & 14,6 & 11,8 & $-22,9$ & 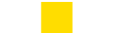 & 24 & 20 & 18 & 13 & -44 & \\
\hline Indonesia & 224,7 & 28,9 & 22,0 & 30,4 & 29,7 & 2,9 & 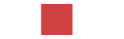 & 16 & 11 & 15 & 13 & -17 & \\
\hline Malasia & 26,6 & n.s. & n.s. & n.s. & n.s. & n.d. & & - & - & - & - & n.d. & \\
\hline Rep. Dem. Pop. Lao & 6,1 & 1,3 & 1,4 & 1,4 & 1,4 & 3,1 & & 31 & 29 & 26 & 22 & -27 & \\
\hline Tailandia & 67,0 & 15,0 & 11,1 & 11,5 & 10,7 & $-28,9$ &  & 26 & 18 & 18 & 16 & -39 & \\
\hline Viet Nam & 86,1 & 21,0 & 16,7 & 13,3 & 9,6 & $-54,5$ & 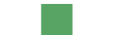 & 31 & 22 & 17 & 11 & -64 & \\
\hline Cáucaso y Asia central & 75,4 & 10,9 & 9,2 & 12,4 & 6,7 & $-38,8$ & & 16 & 13 & 17 & 9 & -45 & \\
\hline Armenia & 3,1 & 1,6 & 1,1 & 0,9 & 0,6 & n.d. & & 45 & 36 & 28 & 21 & -53 & \\
\hline Azerbaiyán & 8,6 & 2,0 & 2,2 & 0,9 & n.s. & $-90,2$ & & 27 & 27 & 11 & - & n.d. & \\
\hline Georgia & 4,4 & 3,1 & 1,0 & 0,5 & 0,3 & $-91,8$ & 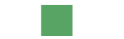 & 58 & 19 & 12 & 6 & -90 & \\
\hline Kazajstán & 15,4 & n.s. & n.s. & 1,2 & n.s. & n.d. & 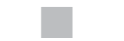 & - & - & 8 & - & n.d. & \\
\hline Kirguistán & 5,3 & 0,8 & 0,6 & 0,9 & 0,6 & $-24,4$ & 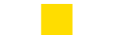 & 17 & 13 & 17 & 11 & -37 & \\
\hline Tayikistán & 6,7 & 1,8 & 2,4 & 2,9 & 1,8 & $-4,6$ & & 34 & 42 & 46 & 26 & -23 & \\
\hline Turkmenistán & 5,0 & 0,3 & 0,4 & 0,4 & 0,3 & 0,9 & - & 9 & 9 & 9 & 7 & -23 & \\
\hline Uzbekistán & 26,9 & 1,1 & 1,2 & 4,7 & 2,8 & 152,6 & 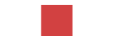 & 5 & 5 & 19 & 11 & 97 & \\
\hline
\end{tabular}


1 Las estimaciones sobre subnutrición mencionadas en este estudio se calculan utilizando la metodología uniforme de la FAO; estas se modifican según proceda para tener en cuenta los datos incompletos sobre la producción y el comercio. Véase FAO. El estado de la inseguridad alimentaria en el mundo 2008. Roma, p. 7.

2 M. Demeke, G. Pangrazio y M. Maetz. 2009. Country responses to the food security crisis: nature and preliminary implications of the policies pursued. Iniciativa de la FAO relativa al aumento de los precios de los alimentos (disponible en: ftp://ftp.fao.org/docrep/fao/011/ ak177e/ak177e00.pdf).

3 J. Piesse y C. Thirtle. 2009. Three bubbles and a panic: An explanatory review of recent food commodity price events. Food Policy, 34(2): 119-129; C.L. Gilbert. 2010. How to understand high food prices. Journal of Agricultural Economics, 61: 398-425; D. Headey y S. Fan. 2010. Reflections on the global food crisis: how did it happen? How has it hurt? And how can we prevent the next one? Instituto Internacional de Investigación sobre Políticas Alimentarias (IFPRI). Monografía de investigación

n. ${ }^{\circ}$ 165. Washington, DC, IFPRI; D. Headey. 2011. Rethinking the global food crisis: The role of trade shocks. Food Policy, 36(2): 136-146; B. Wright y C. Cafiero. 2011. Grain reserves and food security in the Middle East and North Africa. Food Security, 3(Suppl. 1): S61-S76. FAO. 2009. El estado de la inseguridad alimentaria en el mundo 2009. Crisis económicas: repercusiones y enseñanzas extraídas. Roma.

4 Organización de Cooperación y Desarrollo Económicos (OCDE) y FAO. OECD-FAO Agricultural Outlook 2011-2020 (disponible en: www.agri-outlook.org).

5 FAO. 2011. Estado de los recursos de tierras y aguas del mundo para la alimentación y la agricultura (SOLAW). Documento C 2011/32, presentado en el 37. ${ }^{\circ}$ período de sesiones de la Conferencia de la FAO. Roma, 25 de junio a 2 de julio.

6 Los mercados mundiales de la energía son mucho más grandes que los de productos alimenticios básicos. Por tanto, los precios de los productos alimenticios básicos no tendrán efectos importantes en los mercados energéticos mundiales.
7 R. López y G. Galinato. 2007. Should governments stop subsidies to private goods? Evidence from rural Latin America. Journal of Public Economics, 91(5): 1071-1094.

8 FAO. 2009. El estado de la inseguridad alimentaria en el mundo 2009. Crisis económicas: repercusiones y enseñanzas extraídas. Roma.

9 Para una evaluación más detallada de estos datos, véase D. Dawe, S. Block, A. Gulati, J. Huang y S. Ito. 2010. Domestic rice price, trade and marketing policies. En S. Pandey, D. Byerlee, D. Dawe, A. Dobermann, S. Mohanty, S. Rozelle y B. Hardy (editores). Rice in the global economy: strategic research and policy issues for food security, pp. 379407. Instituto Internacional de Investigación sobre el Arroz (IRRI), Los Baños (Filipinas).

10 M.A. Aksoy y A. Isid-Dikmelik. 2008. Are low food prices pro-poor? Net food buyers and sellers in low-income countries. Documento de trabajo n. ${ }^{\circ} 4642$ sobre investigaciones de políticas. Washington, DC, Banco Mundial.

11 M. Ivanic y W. Martin. 2008. Implications of higher global food prices for poverty in low-income countries. Agricultural Economics, 39: 405-416.

12 A. Zezza, B. Davis, C. Azzarri, K. Covarrubias, L. Tasciotti y G. Anríquez. 2008. The impact of rising food prices on the poor. Documento de trabajo n. ${ }^{\circ}$ 08-07 de la División de Economía del Desarrollo Agrícola (ESA). Roma, FAO (disponible en: ftp://ftp.fao.org/ docrep/fao/011/aj284e/aj284e00.pdf).

13 M. Robles y M. Torero. 2010. Understanding the impact of high food prices in Latin America. Economía, 10(2): 117-164. La diferencia entre las conclusiones de Robles y Torero (2010) y de Ivanic y Martin (2008) respecto de las consecuencias de los precios elevados en el Perú (véase la nota 11) se debe muy probablemente a que Robles y Torero utilizaron las fluctuaciones efectivas de los precios, mientras que Ivanic y Martin aplicaron una variación uniforme a los precios de todos los productos básicos.

14 Dawe et al. (2010) (véase la nota 9).
15 El análisis de este informe se centra en los alimentos básicos, al igual que la mayoría de las publicaciones sobre el tema. Esto se debe a la gran proporción de su presupuesto que los pobres destinan a los alimentos básicos, así como a las notables fluctuaciones de los precios de estos productos en los mercados mundiales. La inflación general de los precios de los alimentos presenta menos picos y repuntes menores que la de los precios de los alimentos básicos; no obstante, la cesta utilizada para calcular la inflación de los precios de los alimentos no es representativa de los presupuestos de los pobres y, por tanto, resulta menos pertinente desde el punto de vista de la seguridad alimentaria.

16 S. Block, L. Kiess, P. Webb, S. Kosen R. Moench-Pfanner, M.W. Bloem y C.P. Timmer. 2004. Macro shocks and micro outcomes: child nutrition during Indonesia's crisis. Economics and Human Biology, 2(1): 21-44.

17 H. Torlesse, L. Kiess y M.W. Bloem. 2003. La asociación entre el gasto de arroz de los hogares y el estado nutricional de los niños muestra la influencia de las políticas macroeconómicas alimentarias en la lucha contra la malnutrición. Journal of Nutrition, 133(5): 1320-1325

18 A. de Brauw. 2011. Migration and child development during the food price crisis in El Salvador. Food Policy, 36(1): 28-40.

19 A. D'Souza y D. Jolliffe. 2010. Rising food prices and coping strategies: Householdlevel evidence from Afghanistan. Documento de trabajo n. ${ }^{\circ} 5466$ sobre investigaciones de políticas. Washington, DC, Banco Mundial.

20 FAO. 2008. El estado de la inseguridad alimentaria en el mundo 2008. Los precios elevados de los alimentos y la seguridad alimentaria: amenazas y oportunidades. Roma; N. Kumar y A. Quisumbing. 2011. Gendered impacts of the 2007-08 food price crisis: evidence using panel data from rural Ethiopia. IFPRI Documento de debate n. 01093. Washington, DC, IFPRI.

21 S. Bhalotra y M. Umaña-Aponte. 2009. Distress work amongst women? Micro data evidence from 66 developing countries on women's work participation as an insurance device. Departamento de Economía de la Universidad de Bristol, Bristol (Reino Unido) 
22 J. Aranda, 2000. Respuestas campesinas a la crisis del café: Las mujeres cafetaleras se organizan. En J. Aranda, C. Botey y R. Robles (editores). Tiempo de crisis, tiempo de mujeres. Oaxaca (México) Universidad Autónoma Benito Juárez de Oaxaca.

23 M. Floro. 1995. Women's well-being poverty and work intensity. Feminist Economics, 1(3): 1-25.

24 S. Baird y N.S. Friedman. 2007. Aggregate income shocks and infant mortality in the developing world. Documento de trabajo n. ${ }^{\circ} 4346$ sobre investigaciones de políticas. Washington, DC, Banco Mundial.

25 A. Chapoto y T.S. Jayne. 2010. Maize price instability in Eastern and Southern Africa: the impact of trade barriers and market interventions. Ponencia presentada en el seminario sobre políticas del Mercado Común para África Oriental y Meridional (COMESA), "Variaciones de los precios de los alimentos básicos: causas, consecuencias y opciones sobre políticas", Maputo (Mozambique), de 25 al 26 de enero de 2010 (disponible en: http://programmes.comesa.int attachments/186 AAMP Maize price instability (7 Jan).pdf)

26 K. Basu. 1986. The market for land: an analysis of interim transactions. Journal of Development Economics, 20(1): 163 177.

27 Para más información sobre los efectos macroeconómicos y políticos, véase: C.P. Timmer y D. Dawe. 2007. Managing food price instability in Asia: a macro food security perspective. Asian Economic Journal, 21(1): 1-18; A. Prakash. 2011. Why volatility matters. En A. Prakash (editor) Safeguarding food security in volatile global markets. Roma, FAO (disponible en: http://www.fao.org/economic/est/ volatility/vgm/es/); R. Arezki y M. Bruckner. 2011. Food prices and political instability. Documento de trabajo n. ${ }^{\circ}$ 11/62 del Fondo Monetario Internacional (FMI). Washington, DC, FMI.

28 S. Gillespie, A. Niehof y G. Rugalema. 2010. AIDS in Africa: dynamics and diversity of impacts and response. En A. Niehof, G. Rugalema y S. Gillespie (editores). AIDS and rural livelihoods. Londres, Earthscan.
29 H. Kazianga y C. Udry. 2006. Consumption smoothing? Livestock, insurance and drought in rural Burkina Faso. Journal of Development Economics, 79(1): 413-446.

30 M. Grimm. 2011. Does household income matter for children's schooling? Evidence for rural sub-Saharan Africa. Economics of Education Review, 30: 740-754; D. Cogneau y R. Jedwab. 2008. Household income and investments in child health and education in Ivory Coast. Escuela de Economía de París (mimeo).

31 J.E. Baez e I.V. Santos. 2007. Children's vulnerability to weather shocks: A natural disaster as a natural experiment. Nueva York (Estados Unidos de América), Red de nvestigación en Ciencias Sociales (disponible en: http://siteresources. worldbank.org/INTMIGDEV/ Resources/2838212-1237254959508/ Children_Vulnerability_to_Shocks Hurricane_Mitch_in_Nicaragua_as_a_ Natural_Experiment.pdf)

32 J. Hoddinott. 2006. Shocks and their consequences across and within households in rural Zimbabwe. Journal of Development Economics, 42(2): 301-321.

33 Banco Mundial. 2006. Repositioning nutrition as central to development: a strategy for large-scale action Washington, DC; J. Hoddinott. 2009. Early childhood nutrition increases adult wages. EuroChoices, 8 (Número especial): 34-37: J.A. Maluccio, J. Hoddinott, J.R. Behrman, R. Martorell, A.R. Quisumbing y A.D. Stein. 2009. The impact of improving nutrition during early childhood on education among Guatemalan adults. Economic Journal, 119 (537): 734-763.

34 S. Maccini y Dean Yang. 2009. Under the weather: Health, schooling, and economic consequences of early-life rainfall. American Economic Review, 99(3): 1006-1026.

35 M.R. Carter, P.D. Little, T. Mogues y W. Negatu. 2007. Poverty traps and natural disasters in Ethiopia and Honduras. World Development, 35(5): 835-856

36 Fondo Internacional de Desarrollo Agrícola (FIDA). 2010. Informe sobre la pobreza rural. Roma.
37 M.R. Rosenzweig y K.I. Wolpin. 1993 Credit market constraints, consumption smoothing, and the accumulation of durable production assets in low-income countries: investments in bullocks in India. Journal of Political Economy, 101(2): 223-244

38 T. Kurosaki y M. Fafchamps. 2002. Insurance market efficiency and crop choices in Pakistan. Journal of Development Economics, 67(2) 419-453.

39 S. Dercon y L. Christiaensen. 2011. Consumption risk, technology adoption and poverty traps: evidence from Ethiopia. Journal of Development Economics (en prensa).

40 OCDE-FAO (2011) (véase la nota 4)

41 Robles y Torero (2010) (véase la nota 13).

42 N. Minot. 2011. Transmission of world food price changes to markets in subSaharan Africa. IFPRI Documento de debate $n .{ }^{\circ} 01059$. Washington, DC, IFPRI.

43 Demeke, Pangrazio y Maetz (2009) (véase la nota 2).

44 Véase D. Dawe (editor) 2010. The rice crisis: markets, policies and food security. London, Earthscan y Roma, FAO, especialmente C. Fang, How China stabilized grain prices during the global price crisis; A. Gulati y M. Dutta, Rice policies in India in the context of the global rice price spike; y A. Saifullah, Indonesia's rice policy and price stabilization programme: managing domestic prices during the 2008 crisis.

45 A. Shepherd. 2005. Review of the role of the private sector in meeting food emergencies in Zambia. Roma, FAO (disponible en: http://www.fao.org/ fileadmin/templates/ags/docs/marketing/ esa/zambia.pdf).

46 Véase Chapoto y Jayne (2010) (nota 25)

47 La inflación acumulada fue de un $20 \%$ aproximadamente tanto en los Estados Unidos de América como en los países del África occidental que utilizaban el franco CFA en ese período, por lo que el ajuste en función de la inflación no modificaría en medida importante los resultados. 
48 Algunas políticas de Tailandia (por ejemplo, los precios de apoyo internos) pueden afectar indirectamente al nivel de exportaciones. Sin embargo, los precios internos de Tailandia vienen fluctuando casi perfectamente a la par con los precios mundiales desde 1986

49 G. Rapsomanikis y A. Sarris. 2008. Market integration and uncertainty: the impact of domestic and international commodity price variability on rural household income and welfare in Ghana and Peru. Journal of Development Economics, 44(9): 1354-1381.

50 P. Dorosh. 2009. Price stabilization, international trade and cereal stocks: world price shocks and policy response in South Asia. Food Security, 1: 137-149.

51 La muestra incluye todos los países de África de los que se dispone de información sea sobre el arroz o a el trigo y un alimento básico tradicional. En el análisis se han utilizado todos los datos disponibles de 2005 a 2010.

52 F.T. Portmann, S. Siebert y P. Döll. 2010 MIRCA2000 - Global monthly irrigated and rainfed crop areas around the year 2000: A new high-resolution data set for agricultural and hydrological modeling. Global Biogeochemical Cycles, 24, GB1011, 24 pp. doi:10.1029/2008GB003435.

53 A. Quisumbing, R. Meinzen-Dick, L. Bassett, M. Usnick, L. Pandolfelli, C. Morden y H. Alderman. 2008. Helping women respond to the global food price crisis. IFPRI Nota de orientación n. ${ }^{\circ} 7$ Washington, DC, IFPRI.

54 D. Dawe. 2010. Cereal price transmission in several large Asian countries during the global food crisis. Asian Journal of Agriculture and Development, 6(1): 1-12; M. Hossain y U. Deb. 2010. Volatility in rice prices and policy responses in Bangladesh. En D. Dawe (editor), The rice crisis: markets, policies and food security. Londres, Earthscan y Roma, FAO

55 I. Maltsoglou e Y. Khwaja. 2010. Bioenergy and food security: the BEFS analysis for Tanzania. Documento de trabajo n. ${ }^{\circ} 35$ sobre gestión del medio ambiente y los recursos naturales. Roma, FAO.
56 H. Höffler y B.W. Owuor Ochieng. 2009 High commodity prices - who gets the money? A case study on the impact of high food and factor prices on Kenyan farmers. Berlín, Fundación Heinrich-Böll (disponible en: http://www.boell.de/ downloads/worldwide/HighFoodPricesWhoGetsTheMoney_Kenya.pdf).

57 B. Hill. 2008. Shaking the invisible hand Rice Today, 7(4): 26-31.

58 P.F. Moya, D. Dawe, D. Pabale, M. Tiongco, N.V. Chien, S. Devarajan, A. Djatiharti, N.X. Lai, L. Niyomvit, H.X. Ping, G. Redondo y P. Wardana. 2004. The economics of intensively irrigated rice in Asia. En A. Dobermann, C. Witt y D. Dawe (editores). Increasing the productivity of intensive rice systems through site-specific nutrient management, pp. 29-58. Enfield, New Hampshire (Estados Unidos de América), Science Publishers, y Los Baños (Filipinas), IRRI.

59 S. Descargues. 2011. Impact of food price volatility on incomes and investment of smallholder farmers in Bangladesh. Roma, FAO.

60 Höffler y Owuor Ochieng (2009) (véase la nota 56).

61 D.Headey, S. Malaiyandi y S. Fan. 2010 Navigating the perfect storm: reflections on the food, energy and financial crises. Agricultural Economics, 41(s1): 217-228

62 K.S. Imai, R. Gaiha y G. Thapa. 2011. Supply response to changes in agricultural commodity prices in Asian countries. Journal of Asian Economics, 22: 61-75.

63 J. Subervie. 2008. The variable response of agricultural supply to world price instability in developing countries. Journal of Agricultural Economics, 59(1): 72-92.

64 Véase Shepherd (2005) (nota 45) y Chapoto y Jayne (2010) (nota 25).

65 Con frecuencia los controles del comercio hacen crecer los precios internos por encima de los mundiales; en estos casos dichas políticas se suman al suministro mundial.

66 Véase Shepherd (2005) (nota 45).
67 P. Villers y M. Gummert. 2009. Seal of approval: Hermetic storage of rice is becoming increasingly popular across Asia. Rice Today, 8(1): 36-37.

68 J.M. Harris, K. Erickson, J. Johnson, M. Morehart, R. Strickland, T. Covey, C. McGath, M. Ahearn, T. Parker, S. Vogel, R. Williams y R. Dubman. 2009. Agricultural income and finance outlook. Washington, DC. Departamento de Agricultura de los Estados Unidos (disponible en: http://usda.mannlib. cornell.edu/usda/ers/AIS//2000s/2009/AIS 12-22-2009.pdf)

69 A.B. Banful. 2011. Old problems in the new solutions? Politically motivated allocation of program benefits and the "new" fertilizer subsidies. World Development, 39(7): 1166-1176.

70 B. Tortora y A. Rzepa. 2011. Recent trends in food security: a perspective from sub-Saharan Africans. Gallup Social and Economic Analysis.

71 E. Ligon y E. Sadoulet. 2007. Estimating the effects of aggregate agricultural growth on the distribution of expenditures. Estudio de antecedentes para el Informe sobre el desarrollo mundial, 2008 (disponible en http://siteresources.worldbank.org/ INTWDR2008/ Resources/2795087-1191427986785/ LigonE\&SadouletE EstimatingEffectsOfAggAgGr.pdf).

72 S. Daidone y G. Anríquez. 2011. An extended cross-country database for agricultural investment and capital. Documento de trabajo de la ESA n. ${ }^{\circ}$ 11-16. Roma, FAO (disponible en http://www.fao.org/docrep/014/am640e/ am640e00.pdf).

73 FAO. 2009b. Investment. Issues Brief. Foro de Expertos de Alto Nivel sobre "Cómo alimentar al mundo en 2050" (disponible en: http://www.fao.org/ fileadmin/templates/wsfs/docs/Issues papers/HLEF2050_Investment.pdf)

74 S. Fan, 2008. Public expenditures, growth, and poverty: lessons from developing countries. Baltimore, MD, Johns Hopkins University Press. 



\section{NOTAS al cuadro del Anexo}

1. Objetivo de la Cumbre Mundial sobre la Alimentación: reducir a la mitad, entre 1990-92 y 2015, el número de personas subnutridas.

2. Objetivo de Desarrollo del Milenio 1, Meta 1.C: reducir a la mitad, entre 1990 y 2015, la proporción de personas que padecen hambre. Indicador 1.9: Proporción de la población por debajo del nivel mínimo de consumo de energía alimentaria (subnutrición). Los resultados se obtienen siguiendo una metodología armonizada, y se basan en un promedio de tres años de los datos más recientes disponibles globalmente. Es posible que algunos países tengan datos más recientes, y usarlos podría llevar a estimaciones diferentes sobre la prevalencia de la subnutrición, y, en consecuencia, del progreso alcanzado.

3. El último período de notificación es 2006-08 y los valores de referencia corresponden a 1990-92. En el caso de los países que no existían en el período de referencia, la proporción de personas subnutridas de 1990-92 se basa en el período 1993-95 y el número de personas subnutridas se basa en su población de 1990-92 y en la proporción correspondiente.

4. El indicador de color muestra el progreso que, según las previsiones, se logrará para el año 2015 si continúa la tendencia actual:

El objetivo ya ha sido alcanzado

o se espera que haya sido alcanzado para 2015

Progreso insuficiente para alcanzar

el objetivo si la tendencia actual persiste

Progreso nulo o deterioro

El país tiene una proporción inferior al

$5 \%$ de personas subnutridas

Los países revisan periódicamente sus estadísticas oficiales correspondientes al pasado y al último período para el que se ha presentado información. Lo mismo vale para los datos sobre población de las Naciones Unidas. Cuando esto ocurre, la FAO modifica en consecuencia sus cifras relativas a la subnutrición. Por este motivo se aconseja a los usuarios que consideren los cambios en las estimaciones a lo largo del tiempo únicamente dentro de una misma edición de El estado de la inseguridad alimentaria en el mundo, evitando comparar datos publicados en ediciones de distintos años.

Países que integran los grupos especiales: países menos adelantados, países en desarrollo sin litoral y pequeños Estados insulares en desarrollo:

5. Incluye a: Afganistán, Angola, Bangladesh, Benin, Burkina Faso, Burundi, Camboya, Chad, Comoras, Dijbouti, Eritrea, Etiopía, Gambia, Guinea, Guinea-Bissau, Haití, Islas Salomón, Kiribati, Lesotho, Liberia, Madagascar, Malawi, Malí, Mauritania, Mozambique, Myanmar, Nepal, Níger, República Centroafricana, República Democrática del Congo República Democrática Popular Lao, República Unida de Tanzanía, Rwanda, Samoa, Santo Tomé y Príncipe, Senegal, Sierra Leona, Somalia, Sudán, Timor-Leste, Togo, Uganda, Vanuatu, Yemen y Zambia.
6. Incluye a: Afganistán, Armenia, Azerbaiyán, Bolivia (Estado Plurinacional de), Botswana, Burkina Faso, Burundi, Chad, Etiopía, ex República Yugoslava de Macedonia, Kazajstán, Kirguistán, Lesotho, Malawi, Malí, Mongolia, Nepal, Níger, Paraguay, República Centroafricana, República Democrática Popular Lao, República de Moldova, Rwanda, Swazilandia, Tayikistán, Turkmenistán, Uganda, Uzbekistán, Zambia y Zimbabwe.

7. Incluye a: Antigua y Barbuda, Antillas Neerlandesas, Bahamas, Barbados, Belice, Cabo Verde, Comoras, Cuba, Dominica, Fiji, Granada, Guinea-Bissau, Guyana, Haití, Islas Salomón, Jamaica, Kiribati, Maldivas, Mauricio, Nueva Caledonia, Papua Nueva Guinea, Polinesia Francesa, República Dominicana, Saint Kitts y Nevis, Samoa, Santa Lucía, Santo Tomé y Príncipe, San Vicente y las Granadinas, Seychelles, Suriname, Timor-Leste, Trinidad y Tabago y Vanuatu.

No se han incluido en el cuadro los países en desarrollo respecto a los cuales no se disponía de suficientes datos.

8. Además de los países enumerados en el cuadro, incluye a los siguientes: Cabo Verde, Comoras, Djibouti, Guinea-Bissau, República Democrática del Congo, Somalia, Santo Tomé y Príncipe y Seychelles.

9. Además de los países enumerados en el cuadro, incluye a Belice.

10. Además de los países enumerados en el cuadro, incluye a los siguientes: Antigua y Barbuda, Antillas Neerlandesas, Bahamas, Barbados, Dominica, Granada, Saint Kitts y Nevis, Santa Lucía y San Vicente y las Granadinas.

11. Además de los países enumerados en el cuadro, incluyen a los siguientes: Afganistán y las Maldivas.

12. Además de los países enumerados en el cuadro, incluye a los siguientes: Iraq y los territorios palestinos ocupados.

13. Además de los países enumerados en el cuadro, incluye a los siguientes: Brunei Darussalam, Myanmar, y Timor-Leste.

14. Incluye: Fiji, Islas Salomón, Kiribati, Nueva Caledonia, Papua Nueva Guinea, Polinesia Francesa, Samoa y Vanuatu.

\section{LEYENDA}

- $\quad$ proporción inferior al $5 \%$ de personas subnutridas

n.d. no disponible

n.s. cifra estadísticamente no significativa

\section{FUENTES}

Población total: Perspectivas relativas a la población de las Naciones Unidas (revisión de 2008).

Subnutrición: Cifras de la FAO. 
Fotografías de la cubierta: Todas las fotografías proceden del archivo MediaBase de la FAO.

Las solicitudes de publicaciones de la FAO se han de dirigir al

GRUPO DE VENTAS Y COMERCIALIZACIÓN

Oficina de Intercambio de Conocimientos, Investigación y Extensión

Organización de las Naciones Unidas para la Alimentación y la Agricultura Viale delle Terme di Caracalla

00153 Roma (Italia)
Correo electrónico: publications-sales@fao.org

Fax: (+39) 0657053360

Sitio web: www.fao.org/icatalog/inter-s.htm 


\title{
El estado de la
}

\section{inseguridad alimentaria en el mundo}

\author{
¿Cómo afecta la volatilidad de los precios internacionales \\ a las economías nacionales y la seguridad alimentaria?
}

En El estado de la inseguridad alimentaria en el mundo 2011 se hace hincapié en las diferentes repercusiones que tuvo la crisis alimentaria mundial de 2006-08 en los distintos países, y que afectó más a los más pobres. Mientras que algunos países grandes lograron hacer frente a las peores consecuencias de la crisis, las poblaciones de muchos países pequeños que dependen de las importaciones registraron un aumento considerable de los precios que, aunque solo fuera temporal, puede tener efectos permanentes en su capacidad de obtener ingresos y de salir de la pobreza en el futuro.

El informe del año en curso se centra en los costos de la volatilidad de los precios de los alimentos, así como en los riesgos y oportunidades que plantean los elevados precios de los alimentos. El cambio climático y la mayor frecuencia de las perturbaciones meteorológicas, el aumento de los vínculos entre los mercados energéticos y agrícolas debido a la creciente demanda de biocombustibles y el aumento de la "financierización" de los productos alimenticios y agrícolas básicos apuntan a que la volatilidad de los precios será una realidad perdurable. En este informe se describen los efectos de dicha volatilidad en la seguridad alimentaria y se presentan opciones en materia de políticas para reducir la volatilidad de una forma efectiva en función de los costos y para controlar dicho fenómeno cuando no se pueda evitar. A este respecto, será esencial proporcionar información sobre los mercados más precisa, crear redes de seguridad que tengan en cuenta las cuestiones de género, diseñadas de antemano y que puedan ponerse en funcionamiento rápidamente en momentos de crisis, e invertir en la agricultura a largo plazo con vistas a aumentar la productividad y la capacidad de recuperación frente a las perturbaciones. 